MENINGKATKAN MINAT BELAJAR SISWA PADA PELAJARAN BAHASA INDONESIA MENGGUNAKAN STRATEGI EVERYONE IS A TEACHER HERE DIKELAS III SDN 74 BONTI - BONTI KABUPATEN MAROS

SKRIPSI

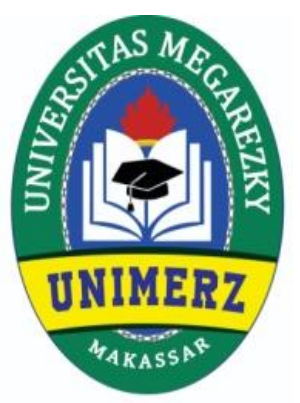

NAVYSEALS ARMADAYANTO

PROGRAM STUDI SARJANA PENDIDIKAN GURU SEKOLAH DASAR FAKULTAS KEGURUAN DAN ILMU PENDIDIKAN UNIVERSITAS MEGAREZKY 2020 


\section{MENINGKATKAN MINAT BELAJAR SISWA PADA PELAJARAN BAHASA INDONESIA MENGGUNAKAN STRATEGI EVERYONE IS A TEACHER HERE DIKELAS III SDN 74 BONTI - BONTI KABUPATEN MAROS}

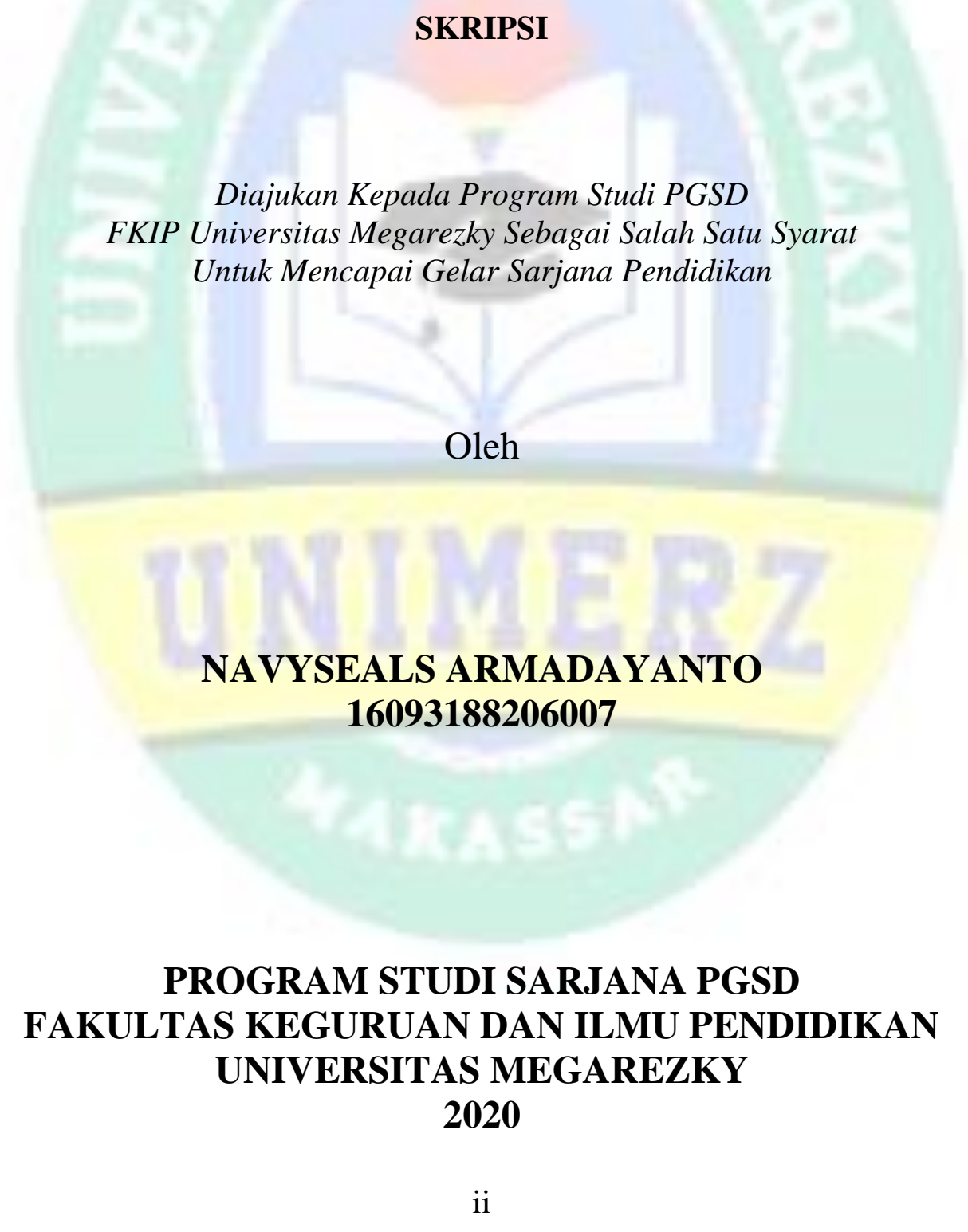




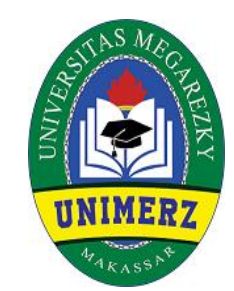

\section{FAKULTAS KEGURUAN DAN ILMU PENDIDIKAN (FKIP) UNIVERSITAS MEGAREZKY}

\section{HALAMAN PENGESAHAN}

Skripsi dengan judul "Meningkatkan Minat Belajar Siswa Pada Pelajaran Bahasa Indonesia Menggunakan Strategi Everyone Is A Teacher Here Dikelas III SDN 74 Bonti-Bonti Kabupaten Maros" atas nama Navyseals Armadayanto, NIM 16093188206007 diterima dan disahkan oleh panitia ujian skripsi berdasarkan surat keputusan Dekan Fakultas Keguruan dan Ilmu Pendidikan (FKIP) Universitas Megarezky Nomor 052/SK/091056.03/XII/2019, tanggal 17 Desember 2019 Sebagai salah satu syarat guna menyelesaikan Program Sarjana dalam Ilmu Keguruan dan Ilmu Pendidikan (FKIP) Universitas Megarezky.

Makassar, 23 September 2020

Panitia Ujian

1. Ketua Penguji : R. Supardi, S.Pd., M.Pd

2. Sekretaris Penguji : Cayati, S.Pd., M.Pd

3. Penguji : Drs. Syamsul Alam, M.Si
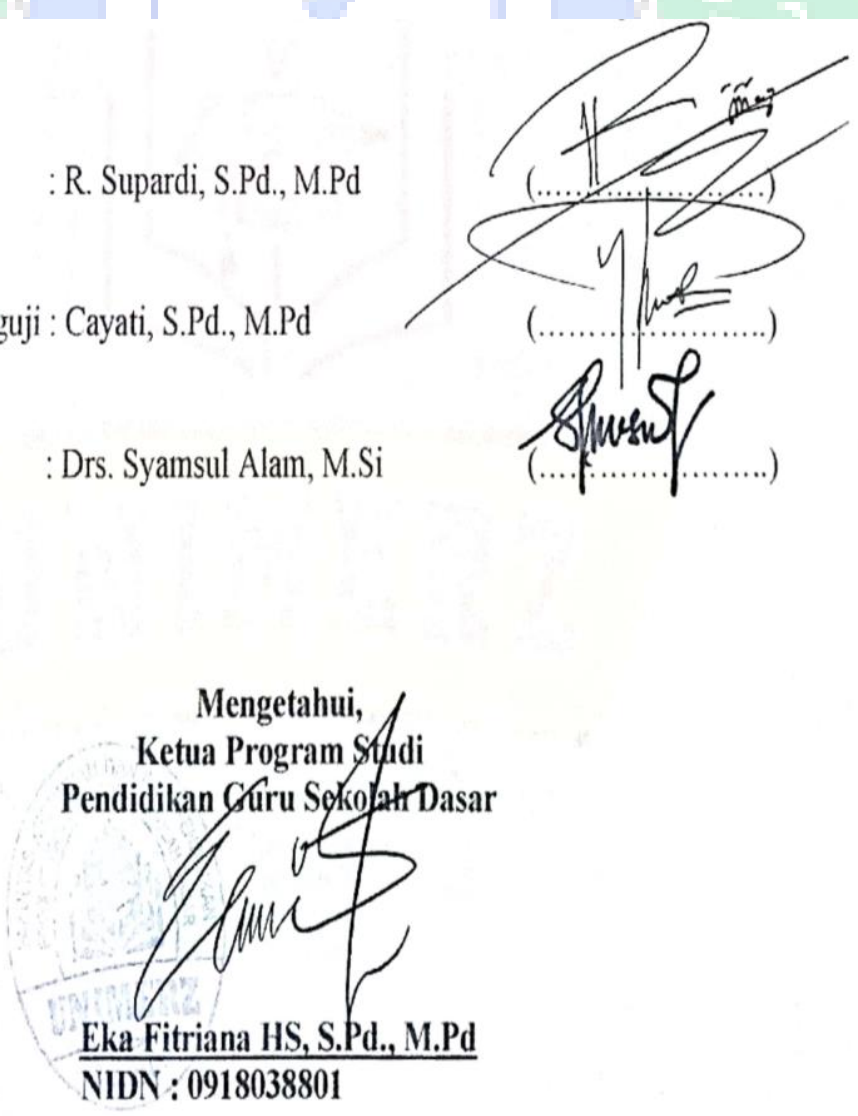


\section{PERSETUJUAN PEMBIMBING}

Pembimbingan yang ditunjuk berdasarkan surat keputusan Dekan FKIP Universitas Megarezky Nomor: 052/SK/091056.03/XII/2019 tanggal 17 Desember 2019 untuk membimbing saudara:

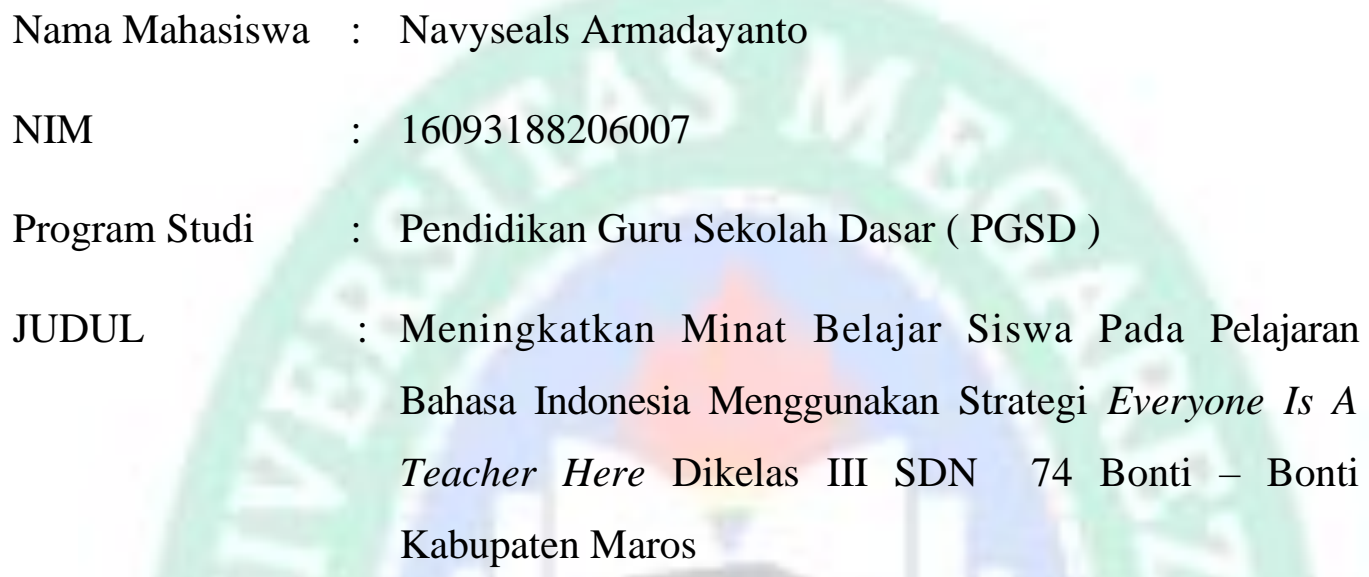
Bahasa Indonesia Menggunakan Strategi Everyone Is A Teacher Here Dikelas III SDN 74 Bonti - Bonti Kabupaten Maros

Menyatakan bahwa skripsi ini telah diperiksa dan dapat diujiankan dihadapan dewan penguji skripsi sarjana (SI) Program Studi Pendidikan Guru Sekolah Dasar FKIP Universitas Megarezky.

Makassar, 23 September 2020

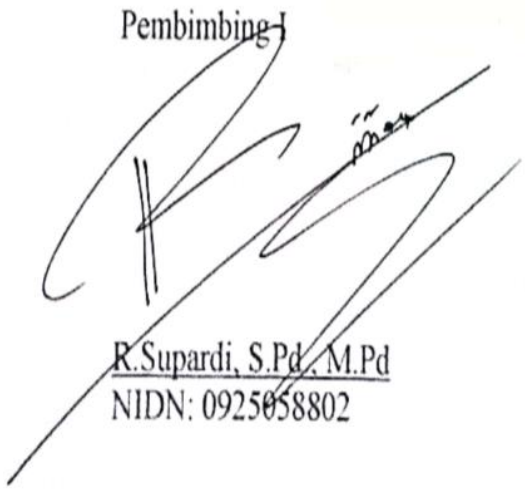

Pembimbing II

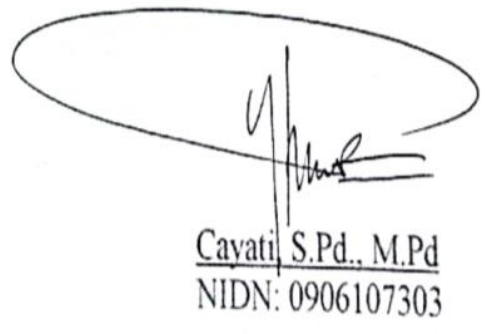




\section{HALAMAN PENGESAHAN}

Judul

:Meningkatkan Minat Belajar Siswa Pada Pelajaran

Bahasa Indonesia Menggunakan Strategi Everyone Is A

Teacher Here Dikelas III SDN 74 Bonti-Bonti Kabupaten

Maros

Nama Mahasiswa : Navyseals Armadayanto

Nim $\quad: 16093188206007$

Program Studi : Pendidikan Guru Sekolah Dasar

Makassar, 23 September 2020

Mahasiswa

Nustura

Navyseals Amnadavanto

Nim: 16093188206007

Menyetujui
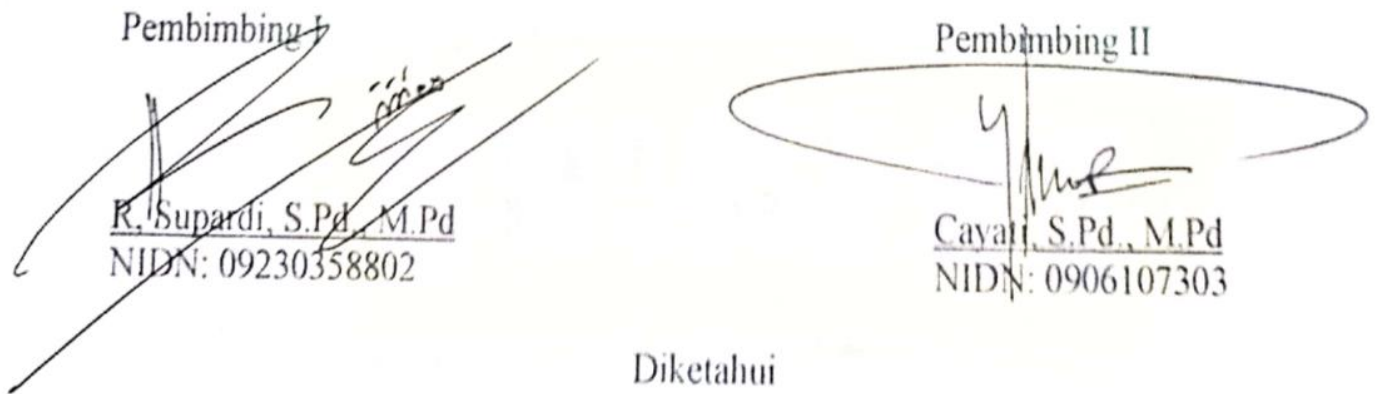

Diketahui

Ketua Program Studi

Pendidikan Guru Sekoyuli Dasar

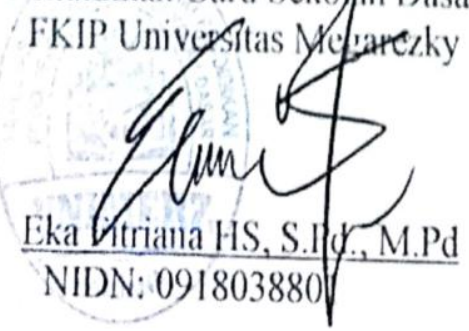




\section{HALAMAN PENGESAHAN}

Judul

: Meningkatkan Minat Belajar Siswa Pada Pelajaran

Bahasa Indonesia Menggunakan Strategi Everyone Is A

Teacher Here Dikelas III SDN 74 Bonti - Bonti Kabupaten Maros

Nama Mahasiswa : Navyseals Armadayanto

Nim

: 16093188206007

Program Studi : Pendidikan Guru Sekolah Dasar

Menyetujui

Komisi Pembimbing
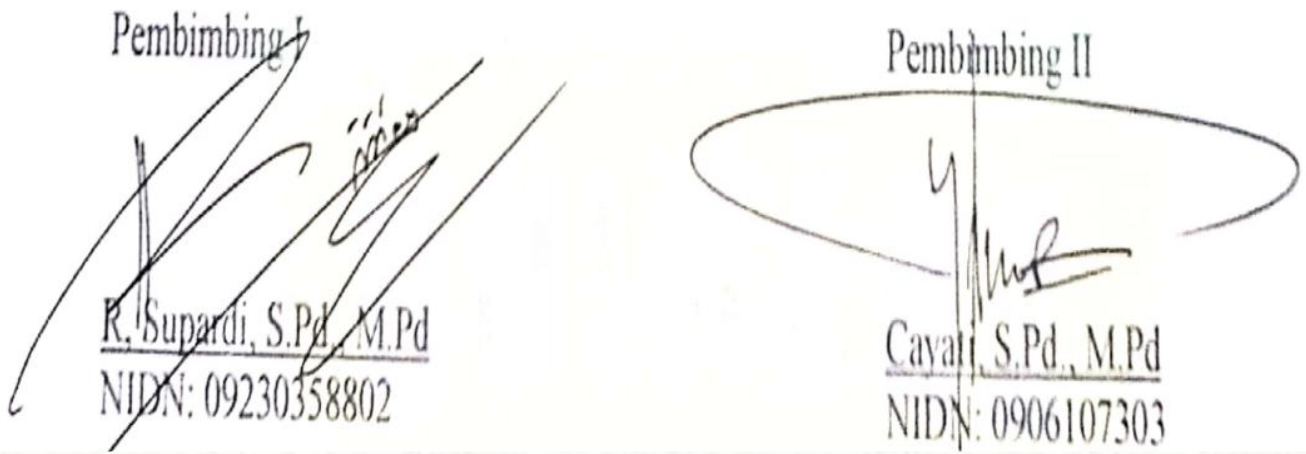

Ketua Program Studi

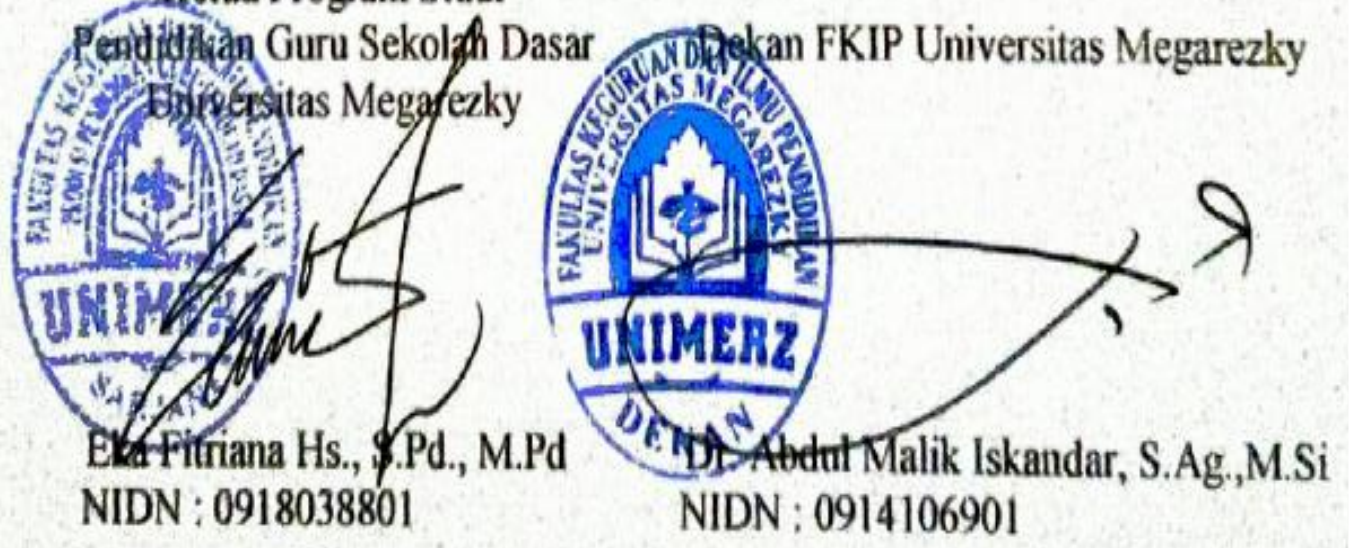




\section{PERNYATAAN KEASLIAN SKRIPSI}

Saya, Navyseals Armadayanto, menyatakan bahwa skripsi yang berjudul: Meningkatkan Minat Belajar Siswa Pada Pelajaran Bahasa Indonesia Menggunakan Strategi Everyone Is A Teacher Here Dikelas III SDN 74 Bonti Bonti Kabupaten Maros,,dibimbing oleh R.Supardi S.Pd.,M.Pd dan Cayati S.Pd.,, merupakan karya asli. Seluruh ide yang ada dalam skripsi ini, kecuali yang saya nyatakan sebagai kutipan, merupakan ide yang saya susun sendiri. Selain itu, tidak ada bagian dari skripsi ini yang telah saya gunakan sebelumnya untuk memperoleh gelar sarjana pendidikan.

Jika pernyataan di atas terbukti sebaliknya, maka saya bersedia menerima sanksi yang ditetapkan oleh FKIP Universitas Megarezky.

Makassar, 23 September 2020 Yang membuat pernyataan

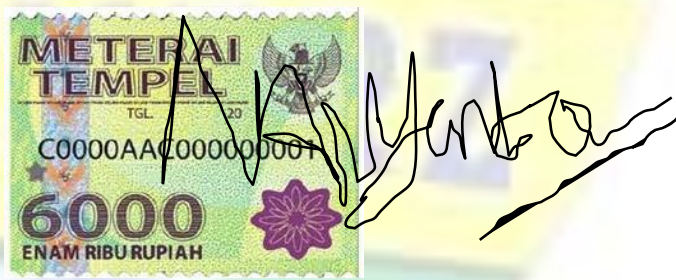

Navyseals Armadayanto

NIM: 16093188206007 


\section{MOTTO DAN PERSEMBAHAN}

\section{MOTTO}

Don't put until tomorrow

What you cant to today

Jangan gunakan sampai besok

Apa yang anda bisa untuk hari ini.

Mengucap syukurlah dalam segala hal, sebab itulah yang di kehendaki Allah

didalam Kristus Yesus bagi kamu.

( 1 Tesalonika $5: 18$ )

\section{PERSEMBAHAN}

Skripsi ini saya persembahkan untuk almamaterku tercinta, kedua orang tuaku, kakak adikku, sahabatsahabat serta teman-teman yang selalu mendukung dan memberikan motivasi hingga selesainya skripsi ini. 


\begin{abstract}
ABSTRAK
Navyseals Armadayanto. 2020. Meningkatkan Minat Belajar Siswa Pada Pelajaran Bahasa Indonesia Menggunakan Strategi Everyone Is A Teacher Here kelas III SDN 74 Bonti - Bonti Kabupaten Maros. Skripsi, Jurusan Pendidikan Guru Sekolah Dasar Universitas megarezky. Pembimbing : R. Supardi dan Cayati

Penelitian ini bertujuan untuk meningkatkan minat belajar Bahasa Indonesia dengan menggunakan strategi Everyone Is A Teacher Here pada siswa kelas III SDN 74 Bonti-Bonti Kabupaten Maros. Jenis penelitian yang digunakan yaitu penelitian Tindakan Kelas dan menggunakan pendekatan kuantitatif. Teknik pengumpulan data menggunakan observasi, angket, tes dan dokumentasi.

Hasil test siklus I dan siklus II, dimana pada siklus I terdapat minat belajar dengan nilai rata-rata kelas $70 \%$ berada pada kategori baik, sedangkan pada siklus II terdapat minat belajar dengan nilai rata-rata kelas $82 \%$ dengan kategori baik. Sehingga dapat dilihat pada peningkatan minat belajar siswa pada siklus II yang mengalami peningkatan yang signifikan.
\end{abstract}

Kata Kunci: Minat Belajar, Bahasa Indonesia, Strategi Everyone Is A Teacher Here 
Navyseals Armadayanto. 2020. Increase Students' Interest In Learning In Indonesian Lessons Using The Everyone Is A Teacher Strategy Here For Class III Of SDN 74 Bonti-Bonti Maros District. Supervised By R. Supardi And Cayati.

This research aimed to know the inprovement of students' interest in learning in Indonesian lessons using the everyone is a teacher strategy here for class III of SDN 74 Bonti-Bonti Maros District. The type of this research used classroom action research (CAR) and used quantitative approach. the data collection tehnique used observation, questionnaire, test and documentation.

The result of cycle I and cycle II, where in the cycle I got students' interest in learning with average value $70 \%$ in the good category, while in the cycle II students' interest in learning with the class average value $82 \%$ with good category. So It can be concluded that there was the inprovement of students' interest in the cycle II which got significant increase.

Keywords: Learning Interest, Indonesian Lessons, Everyone Is A Teacher Strategy Here 


\section{KATA PENGANTAR}

Puji syukur saya panjatkan kehadirat Tuhan Yang Maha Esa atas perlindungannya, sehingga dalam penulisan Skripsi ini dapat di selesaikan dengan baik dengan judul "Meningkatkan Minat Belajar Siswa Pada Pelajaran Bahasa Indonesia Menggunakan Strategi Everyone Is A Teacher Here Dikelas III SDN 74 Bonti - Bonti Kabupaten Maros”. Tulisan ini di susun sebagai salah satu syarat untuk mendapatkan gelar sarjana pada Program Studi Sarjana Pendidikan Guru Sekolah Dasar Fakultas Keguruan dan Ilmu Pendidikan (FKIP), Universitas Megarezky. Penulis menyadari bahwa dalam penyusunan tulisan ini tidak akan selesai tanpa bantuan dari beberapa pihak. Oleh karena itu pada kesempatan ini penulis mengucapkan terimakasih kepada pihak yang telah membantu menyelesaikan penyusunan tulisan ini. Untuk itu, saya mengucapkan terima kasih yang sebesar-besarnya kepada R.Supardi, S.Pd., M.Pd selaku Dosen pembimbing I yang telah membimbing dengan sabar dan telaten serta memberikan banyak motivasi dan saran-saran yang membangun untuk meningkatkan rasa kepercayaan diri penulis. Kepada Cayati, S.Pd., M.Pd selaku dosen Pembimbing II yang telah mengarahkan dengan bijaksana, membimbing dengan penuh kesabaran dan memberikan saran yang sangat bermanfaat.

Dengan kerendahan hati yang tulus penulis mengucapkan terimakasih kepada

1. Dr. H. Alimuddin, SH.,MH., M.Kn selaku Pembina Yayasan Pendidikan Islam Megarezky Makassar. 
2. Hj Suryani SH, MH selaku Ketua Yayasan Pendidikan Islam Megarezky Makassar.

3. Prof. Dr. dr. Ali Aspar Mappahya, Sp.PD., SpJP (K) selaku Rektor Universitas Megarezky.

4. Ns. Julia Fitrianingsi, S.Kes., M.Kep selaku Wakil Rektor I Universitas Megarezky

5. Drs. Abdul Rahman, S.Pd.I., M.Si., M.Pd selaku Wakil Rektor II Universitas Megarezky

6. Dr. Jalal, M.Pd selaku Wakil Rektor III Universitas Megarezky

7. Dr. Hairuddin, KS., SKM., M.Kes Wakil Rektor IV Universitas Megarezky

8. Dr.Abdul Malik Iskandar, S.Ag., M.Si selaku Dekan FKIP Megarezky.

9. Eka Fitriana HS., S.Pd,. M.Pd selaku Ketua Prodi Pendidikan Guru Sekolah Dasar (PGSD)

10. Drs. Syamsul Alam, M.Si selaku Penguji.

11. Sitti Marwiah, S.Pd,i selaku Wali Kelas III di SDN 74 Bonti - Bonti Kabupaten Maros.

12. Hasanuddin K, S.Pd selaku Kepala Sekolah SDN 74 Bonti - Bonti Kabupaten Maros

13. Terimah kasih kepada teman - teman yang membantu dalam menyelesaikan skripsi ini.

Penulis sangat berterimakasih kepada kedua orangtua yang sangat menentukan keberhasilan penulis ayahanda Caya ibunda Marlin paturu atas segala bentuk kasih sayangnya yang telah memberikan moril dan materil kepada 
saya. Semoga Allah selalu melimpahkan berkatNya. Serta saudara-saudaraku yang sangat saya sayangi, terimakasih atas semua dukungannya. Semoga Tuhan melindungi dan membalas atas semua kebaikan yang telah di berikan kepada penulis. Penulis menyadari bahwa dalam penulisan skripsi ini masih banyak terdapat kekurangan, akan tetapi penulis juga tetap akan menantikan kritikankritikan dan saran yang dapat membangun (konsrtuktif). Semoga penulisan ini bermanfaat bagi kita semua. Amin

Makassar, 23 September 2020

Penulis 


\section{DAFTAR ISI}

HALAMAN SAMPUL i

HALAMAN JUDUL ii

HALAMAN PENGESAHAN iii

PERSETUJUAN PEMBIMBING iv

PERNYATAAN KEASLIAN SKRIPSI v v

HALAMAN PENGESAHAN vi

MOTTO vii

ABSTRAK viii

KATA PENGANTAR ix

DAFTAR ISI

DAFTAR BAGAN xiv

DAFTAR TABEL $\quad$ Xv

DAFTAR LAMPIRAN

BAB I PENDAHULUAN
A. Latar Belakang
1
B. Rumusan Masalah 3
C. Tujuan Penelitian 3
D. Manfaat Penelitian 4

BAB II KAJIAN PUSTAKA, KERANGKA PIKIR, HIPOTESIS TINDAKAN
A. Kajian Pustaka
5 
B. Kerangka Pikir $\quad 21$

C. Hipotesis Tindakan 23

\section{BAB III METODE PENELITIAN}

A. Pendekatan dan Jenis Penelitian 24

B. Fokus Penelitian 25

C. Setting dan Subjek Penelitian 25

D. Desain Penelitian 26

$\begin{array}{ll}\text { E. Instrumen Penetian } & 29\end{array}$

F. Teknik Pengumpulan Data 31

G. Teknik Analisis Data 32

H. Indikator Keberhasilan 36

BAB IV HASIL PENELITIAN DAN PEMBAHASAN

A. Hasil Penelitian 37

B. Pembahasan 52

BAB V KESIMPULAN DAN SARAN

DAFTAR PUSTAKA $\quad 35$

\section{LAMPIRAN}

RIWAYAT HIDUP 


\section{DAFTAR BAGAN}

No Judul Bagan

$2.1 \quad$ Kerangka pikir

2.2 Siklus penelitian

\section{Halaman}

22

26 


\section{DAFTAR TABEL}

No Judul Tabel

4.1 Observasi aktivitas guru siklus I

4.2 Observasi aktivitas siswa siklus I

4.3 Distribusi frekuensi siklus I

4.4 Observasi aktivitas guru siklus II

4.5 Observasi aktivitas siswa siklus II

4.6 Distribusi freskuensi siklus II
Halaman

39

40

41

47

48

49 


\section{DAFTAR LAMPIRAN}

No Judul Lampiran

1 RPP siklus I dan II

2 Materi ajar siklus I dan II

3 Observasi aktivitas guru dan siswa siklus I dan II

$4 \quad$ Angket dan minat belajar

$5 \quad$ Validasi instrumen angket dan tes

6 Dokumentasi

$7 \quad$ Persuratan

\section{Halaman}

58

74

83

90

96

97

102 


\section{BAB I}

\section{PENDAHULUAN}

\section{A. Latar Belakang}

Pendidikan adalah sebagai usaha sadar dan terencana untuk mewujudkan suasana belajar dan proses pembelajaran untuk siswa secara aktif mengembangkan potensi dirinya untuk memiliki kekuatan spiritual keagamaan, pengendalian diri, kepribadian, kecerdasan, akhlak mulia, serta keterampilan yang diperlukan dirinya dan masyarakat. Dimyanti \& Mudjiono (2015: 7), pendidikan adalah proses interaksi yang memiliki tujuan. Pendapat ini menunjukan bahwa dapat di katakan sebagai pendidikan jika adanya proses interaksi antara guru dan siswa yang mendorong terjadinya belajar.

Definisi pendidikan sebagaimana tercantum dalam UU Sisdiknas No. 20 Tahun 2003 bahwa Pendidikan Nasional adalah Pendidikan yang berdasarkan Pancasila dan UU 1945 yang berakar pada nilai-nilai Agama, Kebudayaan Nasional Indonesia dan tanggap terhadap tuntutan perubahan jaman. Sisdiknas di rumuskan dengan misi utama dapat memberikan pendidikan dasar bagi setiap warga negara Republik Indonesia, agar setiap warga negara memperoleh sekurang-kurangnya pengetahuan dan kemampuan dasar Abdul Kadir, dkk (2014: 198).

Minat belajar siswa dalam mengikuti pembelajaran merupakan sesuatu yang penting dalam kelancaran proses belajar mengajar. Siswa yang mempunyai minat belajar tinggi dalam proses pembelajaran dapat menunjang proses belajar mengajar untuk semakin baik, begitupun sebaliknya minat belajar siswa yang 
rendah maka kualitas pembelajaran akan menurun dan akan berpengaruh pada hasil belajar. Slameto (2010: 57) menerangkan minat adalah "Kecenderungan hati yang tinggi terhadap sesuatu”. Minat merupakan sifat yang relatif menetap pada diri seseorang. Minat adalah ketertarikan atau kecenderungan yang tetap untuk memperhatikan atau terlibat terhadap sesuatu hal karena menyadari pentingnya atau bernilainya hal tersebut.

Dengan menggunakan strategi yang bervariasi akan mengurangi tingkat kebosanan siswa dan akan meningkatkan minat siswa dalam belajar. Bahasa Indonesia merupakan salah satu hasil kebudayaan yang harus dipelajari dan diajarkan. Dengan bahasa, kebudayaan suatu bangsa dapat dibentuk, dibina, dan dikembangkan kepada generasi - generasi mendatang. Pengajaran bahasa Indonesia pada hakekatnya merupakan salah satu upaya mengembangkan dan membina bahasa Indonesia secara terarah. Maka dari itu melalui proses pengajaran bahasa diharapkan siswa mempunyai kemampuan yang memadai untuk dapat mengguanakan bahasa Indonesia dengan baik dan benar.

Minat belajar mengikuti pembelajaran siswa SDN 74 Bonti - Bonti kelas III sangat kurang. Masalah yang sangat crusial adalah kebanyakan siswa yang sering berbicara sendiri dalam proses belajar mengajar yang sangat mengganggu keberlangsungan proses belajar mengajar, karena dapat mengganggu siswa yang lain yang ingin memperhatikan serta bagi siswa yang berbicara sendiri akan tidak dapat menyerap materi lebih baik.

Berdasarkan hasil observasi awal yang di lakukan di SDN 74 Bonti Bonti Kabupaten Maros, bahwa hal yang dominan terlihat pada saat pembelajaran 
Bahasa Indonesia sedang berlangsung yaitu guru lebih banyak menjelaskan dibandingkan dengan melibatkan siswa secara langsung, sehingga pembelajaran masih berpusat pada guru. Siswa kurang diberi kesempatan untuk berperan aktif dalam proses belajar mengajar yang mengakibatkan interaksi antara guru dan siswa tidak terjalin dengan baik. Terlihat dari banyaknya siswa yang kurang memiliki minat dalam pembelajaran.

Berdasarkan masalah di atas maka peneliti akan melakukan penelitian tindakan kelas dengan judul "Meningkatkan Minat Belajar Siswa Pada Pelajaran Bahasa Indonesia Menggunakan Strategi Everyone Is A Teacher Here Di Kelas III SDN 74 Bonti - Bonti Kabupaten Maros."

\section{B. Rumusan Masalah.}

Berdasarkan latar belakang diatas dapat dirumuskan permasalahan penelitian sebagai berikut:

1. Bagaimana pengaruh penggunaan Strategi Everyone Is A Teacher Here Pada Siswa kelas III SDN 74 Bonti - Bonti Kabupaten Maros terhadap minat belajar Bahasa Indonesia?

2. Apa saja faktor yang membuat Strategi Everyone Is A Teacher Here dapat meningkatkan minat belajar Bahasa Indonesia siswa kelas III SDN 74 Bonti - Bonti Kabupaten Maros. 


\section{Tujuan Penelitian.}

Berdasarkan rumusan masalah diatas adapun tujuan secara umum penelitian ini yaitu:

1. Mengetahui pengaruh penggunaan Strategi Everyone Is A Teacher Here Pada Siswa kelas III SDN 74 Bonti - Bonti Kabupaten Maros terhadap minat belajar Bahasa Indonesia?

2. Mengetahui faktor yang membuat Strategi Everyone Is A Teacher Here dapat meningkatkan minat belajar Bahasa Indonesia siswa kelas III SDN 74 Bonti - Bonti Kabupaten Maros

\section{Manfaat Penelitian.}

1. Manfaat Teoritis.
a. Memberitahukan pentingnya sebuah pemilihan strategi pengajaran
b. Memberikan pengalaman dari sebuah pengajaran yang diterapkan
c. Mengembangkan dan mencoba mengaplikasikan atas ilmu dan juga teori yang telah diperoleh dalam bangku perkuliahan.

2. Manfaat Praktis

a. Bagi siswa, dapat meningkatkan Minat belajar siswa.

b. Bagi sekolah, Penelitian ini diharapkan dapat memberikan inspirasi dan rujukan bagi sekolah dan para guru dalam perbaikan pembelajaran dan meningkatkan mutu pembelajaran.

c. Bagi guru, penelitian ini merupakan masukan dalam memperluas pengetahuan dan wawasan tentang Strategi pembelajaran terutama dalam rangka meningkatkan keaktifan belajar siswa. 
d. Bagi peneliti lain, Penelitian ini berguna sebagai bahan referensi untuk melakukan penelitian di bidang pendidikan lebih lanjut. 


\section{BAB II}

\section{KAJIAN PUSTAKA, KERANGKA PIKIR DAN HIPOTESIS TINDAKAN}

\section{A. Kajian Pustaka.}

\section{Pembelajaran Aktif}

Pembelajaran aktif merupakan pendekatan pembelajaran, yang lebih banyak melibatkan aktifitas peserta didik dalam mengakses berbagai informasi dan pengetahuan untuk dibahas dan dikaji dalam proses pembelajaran di kelas, sehingga mereka mendapatkan berbagai pengalaman yang dapat meningkatkan pemahaman dan kompetesinya. Lebih dari itu, belajar aktif memungkinkan peserta didik mengembangkan kemampuan berfikir tingkat tinggi, seperti menganalisis dan mensistensis, serta penilaian terhadap berbagai peristiwa belajar, dan menerapkannya dalam kehidupan sehari-hari. Pembelajaran aktif memiliki persamaan dengan model pembelajaran self discovery learning, yakni pembelajaran yang dilakukan oleh peserta didik untuk menemukan kesimpulan sendiri sehingga dapat dijadikan sebagai nilai yang baru yang dapat di implementasikan dalam kehidupan sehari-hari. Pembelajaran aktif di maksudkan bahwa dalam proses pembelajaran guru harus menciptakan suasana pembelajaran yang dinamis penuh aktifitas, sehingga peserta didik aktif untuk bertanya, mempertanyakan dan mengemukakan gagasan. Belajar merupakan proses aktif dari peserta didik dalam membangun pengetahuan dan keterampilannya. Peserta didik bukanlah gelas kosong yang pasif yang hanya menerima kucuran ceramah sang pendidik tentang pengetahuan atau informasi, tetapi peserta didik adalah 
orang yang menerima sentuhan dengan pendekatan yang variatif menjadikannya belajar.

\section{Strategi Everyone Is A Teacher Here}

a. Konsep Strategi

Secara bahasa, strategi berasal dari bahasa yunani, yaitu "Stategia" yang memiliki magna "seni seorang jendral". Adapun secara istilah, strategi pembelajaran dapat di artikan sebagai suatu pendekatan dalam mengorganisasikan komponen-komponen pembelajaran yang dibutuhkan untuk mencapai tujuan pembelajaran. Menurut Kemp (Isnu Hidayat, 2019: 32) strategi pembelajaran adalah suatu kegiatan yang harus dikerjakan guru dan peserta didik agar tujuan pembelajaran dapat dicapai secara efektif dan efisien.

Menurut Mujiono (Iskandar Wassid \& Dadang Sunendar, 2011: 8) strategi pembelajaran dapat di artikan sebagai Kegiatan pengajar untuk memikirkan dan mengupayakan terjadinya dan mengupayakan terjadinya konsistensi antara aspekaspek dan komponen pembentuk sistem

instruksional, dimana untuk pengajar menggunakan siasat tertentu. Karena sistem instruksional merupakan suatu kegiatan, maka pemikiran dan pengupayakan pengkonsistensian aspek-aspek tidak hanya sebelum di laksanakan, tetapi juga pada saat dilaksanakan. Hal ini di dasarkan pada pemikiran bahwa suatu rancangan tidak selalu tepat pada saat dilakukan. Dengan demikian, strategi pembelajaran memiliki dua dimensi sekaligus. Pertama, strategi pembelajaran pada dimensi perancangan. Kedua, strategi pembelajaran pada dimensi pelaksanaan. 
Menurut Syahruddin (2018: 66) strategi mempunyai pengertian suatu garisgaris besar haluan untuk bertindak dalam usaha mencapai sasaran yang telah ditentukan. Dihubungkan dengan belajar mengajar, strategi bisa diartikan sebagai pola-pola umum kegiatan guru dan anak didik dalam perwujudan kegiatan belajar mengajar untuk mencapai tujuan yang telah digariskan.

Berdasarkan pendapat para ahli dapat disimpulkan bahwa strategi pembelajaran meliputi kegiatan atau pemakaian teknik yang dilakukan oleh pengajar untuk mencapai sasaran yang telah ditentukan mulai dari perecanaan, pelaksanaan kegiatan sampai ke tahap evaluasi, program tindak lanjut yang berlangsung untung mencapai tujuan yaitu pengajaran, serta program prosedur yang sistematik dalam mengorganisasikan pengalaman belajar untuk mencapai tujuan belajar.

\section{b. Pengertian Strategi Everyone Is A Teacher Here}

Strategi Everyone Is A Teacher Here adalah stategi pembelajaran aktif yang mengajak keseluruhan siswa agar dapat terlibat langsung dalam proses belajar mengajar. Esensi dari teknik pembelajaran ini pada hakikatnya seperti teknik pembelajaran pertanyaan atau kuis. Teknik pembelajaran ini sebenarnya mirip dalam pembelajaran kolaboratif Haryanto \& Warsono (2017: 46)

Strategi Everyone Is A Teacher Here (setiap orang adalah guru) memberikan pemahaman kepada para peserta didik bahwa guru bukanlah satusatunya sumber ilmu pengetahuan. Pengetahuan dapat juga di peroleh dari teman sebaya sehingga setiap peserta didik memiliki kesempatan berbagi informasi dengan rekannya sesuai kemampuan masing-masing Isnu Hidayat (2019: 74). 
Dari kedua pendapat di atas dapat disimpulkan bawa strategi Everyone Is A Teacher Here adalah strategi yang memberikan kesempatan bagi setiap orang untuk dapat menjadi guru. Strategi ini merupakan cara yang tepat untuk mendapatkan partisipasi seluruh kelas maupun individu dalam proses belajar mengajar berlangsung. Penyampaian materi yang di sampaikan oleh temannya sendiri akan lebih mudah di mengerti dengan menggunakan bahasa sederhana mereka. Selain temannya mengerti dengan penjelasan yang di berikan, yang memberikan penjelasan pasti lebih mengetahui dengan apa yang di ucapkan.

c. Prosedur Strategi Everyone Is A Teacher Here

Menurut Muhammad Faturrohman (2017: 198) ada 5 prosedur pelaksanaan strategi Everyone Is A Teacher Here:

1) Membagikan kartu/ selembar kertas kepada stiap siswa. Mintalah mereka untuk menuliskan pertanyaan yang mereka miliki tentang materi belajar yang tengah di pelajari di kelas.

2) Setelah mereka selesai menuliskan pertanyaan, kumpulkan kartu atau kertas tadi kemudian kocoklah dan bagikan satu-satu kepada siswa. Perintahkan siswa untuk membaca dalam hati pertanyaan atau topik yang ada di kartu/kertas yang mereka terima dan pikiran jawabannya

3) Tunjuklah beberapa siswa untuk membacakan pertanyaan atau topik yang ada di kartu/kertas yang mereka terima dan memberikan jawabannya. 
4) Setelah memberikan jawaban, mintalah siswa lain untuk menambahkan jawaban atas apa yang telah di kemukakan oleh siswa yang membacakan kartunya itu.

5) Lanjutkan prosedur ini jika waktu memungkinkan.

d. Kelebihan dan Kekurangan Strategi Everyone Is A Teacher Here Ada beberapa kelebihan strategi pembelajaran :

1) Melatih keaktifan siswa dalam kelas.

2) Meningkatkan kemampuan siswa dalam hal memberikan pendapat.

3) Mengajarkan siswa dalam hal bertanggung jawab.

4) Mengarkan siswa dalam menganalisa data.

5) Strategi ini dapat di gunakan pada semua mata pelajaran. Menurut Isnu Hidayat (2019: 76) ada 3 Kekurangan dari Strategi Everyone Is A Teacher Here :

1) Membutuhkan waktu yang cukup lama.

2) Peserta didik akan merasa takut atau canggung bila pendidik tidak mampu memberikan dorongan yang menguatkan mental.

3) Cukup sulit membuat pertanyaan yang mudah dimengerti peserta didik dan sesuai dengan tingkat berpikirnya.

\section{Konsep Minat Belajar}

\section{a. Pengertian minat}

Minat adalah suatu rasa lebih suka dan rasa ingin tahu pada suatu hal atau aktivitas, tanpa ada yang menyuruh. Dengan kata lain minat adalah sesuatu hal yang di lakukan tanpa adanya rasa keterpaksaan. Menurut Slameto (Kompri, 
2015: 268) Minat adalah penerimaan satu hubungan antara diri sendiri dan sesuatu di luar diri. Semakin kuat atau dekat hubungan tersebut maka semakin besar minat untuk melakukan hal tersebut. Kurangnya minat belajar dapat mengakibatkan kurangnya rasa ketertarikan pada suatu bidang tertentu.

Menurut Arvi Riwahyudin (2015: 11) Minat memiliki peranan yang sangat penting dalam kehidupan siswa dan mempunyai dampak yang besar terhadap sikap dan prilaku. Siswa yang berminat terhadap kegiatan belajar akan berusaha lebih keras dibandingkan siswa yang kurang berminat dengan belajar.

Menurut The Liang Gie (Kompri, 2015: 269) dalam hubungannya dengan pemusatan perhatian, minat mempunyai peranan dalam melahirkan perhatian yang serta-merta, memudahkan terciptanya pemusatan perhatian, dan mencegah gangguan perhatian dari berbagai arah.

Berdasarkan beberapa pendapat diatas dapat disimpulkan bahwa minat adalah kebutuhan dan ketertarikan pada suatu hal, yang diperhatikan secara terus menerus tanpa adanya paksaan dari pihak lain. Minat memudahkan terciptanya pemusatan perhatian dalam kehidupan siswa dan mempunyai dampak yang besar terhadap sikap dan prilaku.

\section{b. Faktor-faktor yang Mempengaruhi Minat Belajar}

Faktor-faktor yang mempengaruhi belajar pada hakikatnya terdiri dari dua faktor, yakni faktor internal dan faktor eksternal. Adapun penjelasannya mengenai faktor-faktor tersebut antara lain : 
a. Faktor Internal

Inteligensi Menurut Sriyanti, "Inteligensi merupakan kemampuan penting yang sangat diperlukan bagi keberhasilan belajar seseorang. Inteligensi sendiri berasal dari bahasa latin yaitu intelligere yang berarti to organize, to relate, to bind together, yaitu menghubungkan atau menyamakan satu sama lain.” Menurut W. Stern yang dikutip oleh Purwanto, "Inteligensi adalah kesanggupan untuk menyesuaikan diri kepada kebutuhan baru, dengan menggunakan alat-alat berpikir yang sesuai dengan tujuannya". Sedangkan menurut Vaan Hoes yang dikutip dari Ahmadi, "inteligensi merupakan kecerdasan jiwa." Semakin tinggi kemampuan intelijensi seseorang, maka semakin besar peluangnya untuk meraih sukses. Anak yang memiliki IQ tinggi dapat lebih mudah untuk menyelesaikan segala persoalan yang dihadapi. Sebaliknya, semakin rendah kemampuan inteligensi seseorang siswa maka semakin kecil peluangnya untuk memperoleh sukses.

2) Bakat

a) Pengertian bakat Setiap individu memiliki bakat yang berbeda-beda. Tidak semua anak memiliki bakat di segala bidang. Anak yang berbakat di bidang musik, bisa jadi ia lemah di bidang olah raga atau sebaliknya. Menurut Ahmadi dan Supriyono, "Bakat adalah potensi/kecakapan dasar yang dimiliki sejak lahir." Biasanya bakat sangat bergantung pada pembawaan orang tua. Orang tua yang berkecimpung di bidang kesenian, anaknya akan mudah mempelajari seni suara, tari, dan lain lain yang berhubungan dengan seni.

b. Faktor Eksternal 
1) Keadaan Keluarga Keluarga merupakan pendidikan informal yang diakui dalam dunia pendidikan. Keluarga merupakan fondasi awal akan seperti apa pribadi anak akan terbentuk dan itu juga akan sangat berpengaruh pada pola pikir serta proses belajar anak. Meskipun anak sudah nasuk sekolah, namun harapan masih digantungkan kepada keluarga untuk memberikan pendidikan dan memberikan suasana yang sejuk dan menyenangkan ketika anak belajar di rumah.

2) Guru (pendidik) dan Cara Mendidik Guru merupakan ujung tombak dari pendidikan di sekolah. Tanpa adanya guru, maka tidak akan terjadi prsoes belajar mengajar di institusi pendidikan. Seorang guru memiliki tanggung jawab yang sangat berat, bukan hanya mengemban kewajiban di dalam kelas, namun guru juga memegang peran penting di sekolah dan juga masyarakat.

\section{c. Ciri-Ciri Minat Belajar}

Minat peserta didik dapat timbul dari berbagai sumber antara lain perkembangan insting dan hasrat, fungsi-fungsi intelektual, pengaruh lingkungan, pengalaman, kebiasaan, pendidikan, dan sebagainya.

Pendidik harus mengetahui ciri-ciri minat yang ada pada peserta didik, dengan begitu pendidik dapat membedakan mana peserta didik yang berminat dalam belajar dan mana peserta didik yang tidak berminat dalam belajar, adapun ciri-ciri minat tersebut adalah:

a. Keputusan diambil dengan mempertahankan seluruh kepribadian;

b. Sifatnya irasional;

c. Berlaku perseorangan dan pada suatu situasi;

d. Melakukan sesuatu terbit dari lubuk hati; 
e. Melaksanakan sesuatu tanpa ada paksaan;

f. Melakukan sesuatu dengan senang hati.

Adapun menurut Slameto, peserta didik yang berminat dalam belajar mempunyai ciri-ciri sebagai berikut:

a. Mempunyai kecenderungan yang tetap untuk untuk memperhatikan dan mengenang sesuatu yang dipelajari secara terus menerus.

b. Ada rasa suka dan senang pada sesuatu yang diminati.

c. Memperoleh suatu kebanggaan dan kepuasan pada sesuatu yang diminati. Ada rasa keterikatan pada sesuatu aktivitas-aktivitas yang diminati.

d. Lebih menyukai suatu hal yang menjadi minatnya daripada yang lainnya.

e. Dimanifestasikan melalui partisipasi pada aktivitas dan kegiatan

d. Konsep minat belajar

Proses belajar mengajar minat sangat penting untuk memperoleh hasil belajar yang baik. Kompri (2015: 268) minat belajar adalah kecenderungan siswa terhadap aspek belajar. Minat tidak dibawa sejak lahir melainkan di peroleh kemudian. Minat terhadap sesuatu dipelajari dan memengaruhi belajar selanjutnya serta memengaruhi penerimaan minat-minat baru. Jadi, minat terhadap sesuatu merupakan hasil belajar dan menyokong belajar selanjutnya.

Berdasarkan hasil penelitian psikologi menunjukan bahwa kurangnya minat belajar dapat mengakibatkan kurangnya rasa ketertarikan pada suatu bidang tertentu, bahkan dapat melahirkan sikap penolakan kepada guru. Slameto (Kompri, 2015: 269). 
Menurut Syahruddin (2018: 65) minat belajar adalah sesuatu yang mendorong, menggerakan dan mengarahkan seseorang dalam belajar. Siswa akan memiliki minat dalam pembelajaran jika proses belajar mengajar di dalam kelas membuat siswa nyaman dan tidak membosankan..

Berdasarkan pendapan di atas dapat di beri kesimpulan, bahwa minat belajar adalah keinginan dan ketertarikan siswa terhadap pembelajaran untuk menguasai pengetahuan. Tanpa adanya minat belajar hasil belajar siswa pasti tidak sesuai dengan harapan. Minat sangat mempengaruhi hasil belajar siswa.

Namun secara garis besar faktor-faktor yang mempengaruhi minat dapat dikelompokkan menjadi dua, yaitu yang bersumber dari dalam diri (faktor internal) maupun yang berasal dari luar (faktor eksternal). Faktor internal meliputi niat, rajin, motivasi, dan perhatian. Faktor eksternal meliputi keluarga, guru dan fasilitas sekolah, teman sepergaulan, media massa.

e. Cara meningkatkan minat belajar

Menurut Darliana (Kompri, 2015: 273) ada beberapa cara yang perlu dilakukan guru untuk meningkatkan minat belajar siswa.

1) Perhatikan siswa dengan wajah yang ramah, karena setiap siswa ingin di perhatikan gurunya.

2) Pada saat siswa menjawab atau mengajukan pertanyaan, tataplah siswa itu dengan ramah. Jangan memalingkan muka atau membelakangi siswa. Mereka ingin di hargai, karena itu berilah pengharapan.

3) Jika jawaban siswa salah, guru jangan 
4) marah ataupun langsung menyalahkan siswa, lakukan dengan cara yang dapat membuat siswa termotivasi untuk mengajukan jawaban atau pertanyaan lagi. Guru harus menghargai usaha siswa itu untuk menjawab pertanyaan. Berilah pujian atau penghargaan secukupnya.

5) Jika ada siswa yang diam terus menerus, mintalah siswa itu untuk mengemukakan pendapatnya setelah siswa yang lain menjawab pertanyaan. Setelah siswa itu mengemukakan pendapatnya, berilah pujian atau penghargaan secukupnya.

6) Jangan mengajukan pertanyaan yang dapat di jawab oleh siswa secara serentak.Jika ada siswa yang ingin tampil di depan untuk menjelaskan sesuatu, berilah dia kesempatan untuk menjelaskan. Jika penjelasan siswa itu keliru, maka berilah bantuan yang membuat siswa itu dapat menjelaskan dengan baik.

7) Jangan menyinggung perasaan siswa bagaimnapun kesalahannya. Pada saat siswa melakukan kesalahan pada saat itu muncul peluang yang dapat kita manfaatkan untuk meningkatkan sikap dan minat belajar siswa. Perbaikilah kesalahan siswa dengan cara yang bisa membuat siswa itu tenang.

\section{Pembelajaran Bahasa Indonesia}

\section{a. Pengertian pembelajaran Bahasa Indonesia}

Pembelajaran merupakan terjemahan dari bahasa inggris "instruction" yang terdiri dari 2 kegiatan utama, yaitu belajar (learning) dan mengajar (teaching) kemudian disatukan dalam satu aktivitas, yaitu kegiatan belajar mengajar. Dengan 
demikian pembelajaran adalah ketentuan, kaidah, hukum atau norma yang harus diperhatikan oleh setiap pelaku pembelajaran, agar pembelajaran yang dilaksanakan dapat berjalan secara efektif dan efisien.3 Menurut Peraturan Menteri Pendidikan Nasional (PERMENDIKNAS) Nomor 22 tahun 2006 tentang standar isi pembelajaran bahasa Indonesia diarahkan untuk meningkatkan kemampuan peserta didik untuk berkomunikasi dalam bahasa Indonesia dengan baik dan benar, baik secara lisan maupun tulis, serta menumbuhkan apresiasi terhadap hasil karya kesastraan manusia Indonesia.

Menurut wardhaugh (dalam Solehan 2007: 13) Bahasa adalah sebuah symbol bunyi yang arbiter yang digunakan untuk komunikasi manusia. Menurut Kentjono (dalam Solehan 2007: 14) Bahasa adalah sistem lambang bunyi yang arbiter, yang digunakan oleh para anggota sosial untuk berkomunikasi, bekerja sama, dan mengidentifikasi diri.

Jadi, Bahasa Indonesia adalah alat komunikasi paling Penting untuk mempersatukan seluruh bangsa Indonesia yang merupakan alat pengungkapan diri baik secara lisan maupun tertulis, dari segi rasa, karsa dan cipta, serta pikir, baik secara etis, estetis, maupun secara logis.

\section{b. Kedudukan dan Tujuan Pembelajaran Bahasa Indonesia}

Pembelajaran bahasa Indonesia sejak dini adalah memberikan pelatihan dan pendidikan tentang bahasa sejak awal. Pelaksanaan pendidikan bahasa Indonesia pada anak dapat dilakukan melalui pendidikan informal, pendidikan formal maupun pendidikan nonformal. Pendidikan informal dilakukan oleh keluarga. Pendidikan ini dilakukan saat anak berada di rumah bersama keluarganya. 
Pendidikan formal dilaksanakan dalam lembaga pendidikan resmi mulai dari SD sampai dengan perguruan tinggi.

Dalam pendidikan formal ini guru yang berperan penting dalam memberikan pengetahuan akan bahasa Indonesia. Pendidikan nonformal dilaksanakan di luar rumah dan sekolah dapat melalui kursus, pelatihan pelatihan, serta pondok.

Pendidikan dasar bahasa Indonesia, bahasa Indonesia di lembaga formal dimulai dari SD. Jumlah jam pelajaran Bahasa Indonesia di SD. Sebanyak 6 jam pelajaran dan kelas. Banyak jumlah jam pelajaran bahasa Indonesia agar siswa mempunyai kemampuan berbahasa Indonesia yang baik serta mempunyai kemampuan berpikir dan bernalar yang baik, sehingga dapat disampaikan melalui bahasa yang baik pula.

Kedudukan Bahasa Indonesia, bahasa Indonesia berkedudukan sebagai bahasa nasional, sebagaimana tercantum dalam ikrar Sumpah Pemuda 1912 yang berbunyi: kami putra dan putri Indonesia menjunjung bahasa persatuan, bahasa Indonesia.

Kedudukan bahasa Indonesia berada diatas bahasa - bahasa daerah. Selain itu, dalam UUD 1945 tercantum pada pasal 36, mengenai kedudukan bahasa Indonesia yang menyatakan bahwa bahasa Negara ialah bahasa Indonesia. Dengan kata lain ada dua macam kedudukan bahasa Indonesia. Pertama, bahasa Indonesia berkedudukan sebagai bahasa nasional sesuai dengan Sumpah Pemuda 1928. Kedua, bahasa Indonesia berkedudukan sebagai bahasa Negara sesuai dengan UUD 1945. 
Dalam kedudukannya sebagai Bahasa Nasional, bahasa Indonesia memiliki beberapa fungsi yaitu:

1. Lambang kebanggaan Nasional

Bahasa Indonesia mencerminkan nilai - nilai luhur yang mendasari perilaku bangsa Indonesia.

2. Lambang Identitas Nasional

Bahasa Indonesia mewakili jati diri bangsa Indonesia, selain bahasa Indonesia terdapat pula lambing identitas nasional yang lain yaitu bendera Merah Putih dan lambing antar Negara Garuda Pancasila.

3. Alat Perhubungan antar budaya dan daerah

Masyarakat Indonesia terdiri dari berbagai suku dengan bahasa yang berbeda - beda, maka akan sangat sulit berkomunikasi kecuali ada satu bahasa pokok yang digunakan. Maka dari itu digunakanlah Bahasa Indonesia sebagai alat komunikasi dan perhubungan nasional.

\section{Alat Pemersatu Bangsa}

Mengacu pada keragaman yang ada pada Indonesia dari suku, agama, ras, dan budaya, bahasa Indonesia dijadikan sebagai media yang dapat membuat semua elemen masyarakat yang beragam tersebut kedalam sebuah persatuan dalam kedudukannya sebagai Bahasa Negara, bahasa Indonesia memiliki beberapa fungsi yaitu :

1) Bahasa resmi kenegaraan.

2) Bahasa pengantar di lembaga - lembaga pendidikan. 
3) Bahasa resmi di dalam perhubungan pada tingkat nasional untuk kepentingan perencanaan dan pelaksanaan pembangunan serta pemerintahan.

4) Bahasa resmi didalam pengembangan kebudayaan dan pemanfaatan ilmu pengetahuan dan teknologi.

Tujuan pembelajaran bahasa Indonesia dapat dirumuskan menjadi empat bagian yaitu:

a. Lulusan SD diharapkan mampu menggunakan bahasa Indonesia secara baik dan benar.

b. Lulusan SD diharapkan dapat menghayati bahasa dan sastra Indonesia.

c. Penggunaan bahasa harus sesuai dengan situasi dan tujuan berbahasa.

d. Pengajaran disesuaikan dengan tingkat pengalaman siswa SD.

Pembelajaran bahasa Indonesia di SD dapat memberikan kemampuan dasar berbahasa yang diperlukan untuk melanjutkan pendidikan di sekolah menengah maupun untuk menyerap ilmu yang dipelajari lewat bahasa itu. Dalam pembelajaran bahasa Indonesia perlu diperhatikan pelestarian dan pengembangan nilai - nilai luhur bangsa, serta pembinaan rasa persatuan nasional.

Tujuan pembelajaran bahasa Indonesia dalam BSNP (2006) di jabarkan menjadi beberapa tujuan. Tujuan bagi siswa adalah untuk mengembangkan kemampuan sesuai dengan, kebutuhan, dan minatnya. Serta tujuan bagi guru adalah untuk mengembangkan potensi bahasa siswa, sehingga lebih mandiri 
dalam menentukan bahan ajar kebahasaan sesuai dengan kondisi lingkungan sekolah dan kemampuan siswanya.

Tujuan bagi daerah adalah agar daerah dapat menentukan sendiri bahan dan sumber belajar kebahasaan dengan kondisi kekhasan daerah dengan tetap memperhatikan kepentingan sosial.

Pada prinsipnya tujuan pengajaran bahasa adalah agar siswa terampil berbahasa, yaitu terampil menyimak, berbicara, membaca, dan menulis. Sebenarnya setiap guru yang terlibat dalam proses belajar - mengajar dalam setiap bidang studi pun secara imsplisit adalah guru bahasa juga. Salah satu tujuannya, disadari atau tidak adalah agar para siswa terampil menyimak, berbicara, membaca, dan menulis dalam bidang studi tersebut. Apabila hal ini disadari maka dapat dimengerti betapa pentingnya fungsi bahasa sebagai alat komunikasi, baik secara lisan maupun tulisan.

\section{B. Kerangka Pikir.}

Berdasarkan observasi awal bahwa partisipasi siswa dalam proses pembelajaran masih kurang. Saat pembelajaran berlangsung siswa terlihat kurang aktif dan cepat merasa bosan. Disebabkan strategi yang digunakan guru kurang bervariasi. Hal ini tentu akan berpengaruh terhadap minat belajar siswa pada mata pelajaran Bahasa Indonesia kelas III SDN 74 Bonti - Bonti Kabupaten Maros. Melihat hal ini perlu dilakukan upaya pemecahan masalah melalui penerapan pembelajaran yang membuat siswa lebih aktif dari biasanya.

Penelitian ini menggunakan strategi pembelajaran Everyone Is A Teacher Here merupakan sebuah strategi yang dapat mengaktifkan siswa dalam proses 
belajar mengajar. Srategi pembelajaran ini memberikan kesempatan kepada siswa untuk berperan sebagai guru bagi teman-temannya. Di dalam pembelajaran strategi Everyone Is A Teacher Here ada kegiatan yang sangat menarik yaitu bertukar pertanyaan yang di buat oleh siswa itu sendiri dan siswa itu harus menjawab pertanyaan itu dengan benar, dan siswa lain juga boleh menambahkan jawaban yang ia ketahui.

Strategi pembelajaran Everyone Is A Teacher Here sangat efektif karena siswa ikut serta terlibat langsung dalam proses pembelajaran. Tujuan strategi Everyone Is A Teacher Here yaitu mengarahkan siswa untuk aktif dan bertukar pertanyaan yang di buat oleh siswa itu sendiri kemudian siswa itu harus menjawab pertayaan dengan benar, dan siswa lain juga boleh menambahkan jawaban yang di ketahui. Adapun kerangka pikir dalam penelitian ini dapat di gambarkan sebagai berikut: 


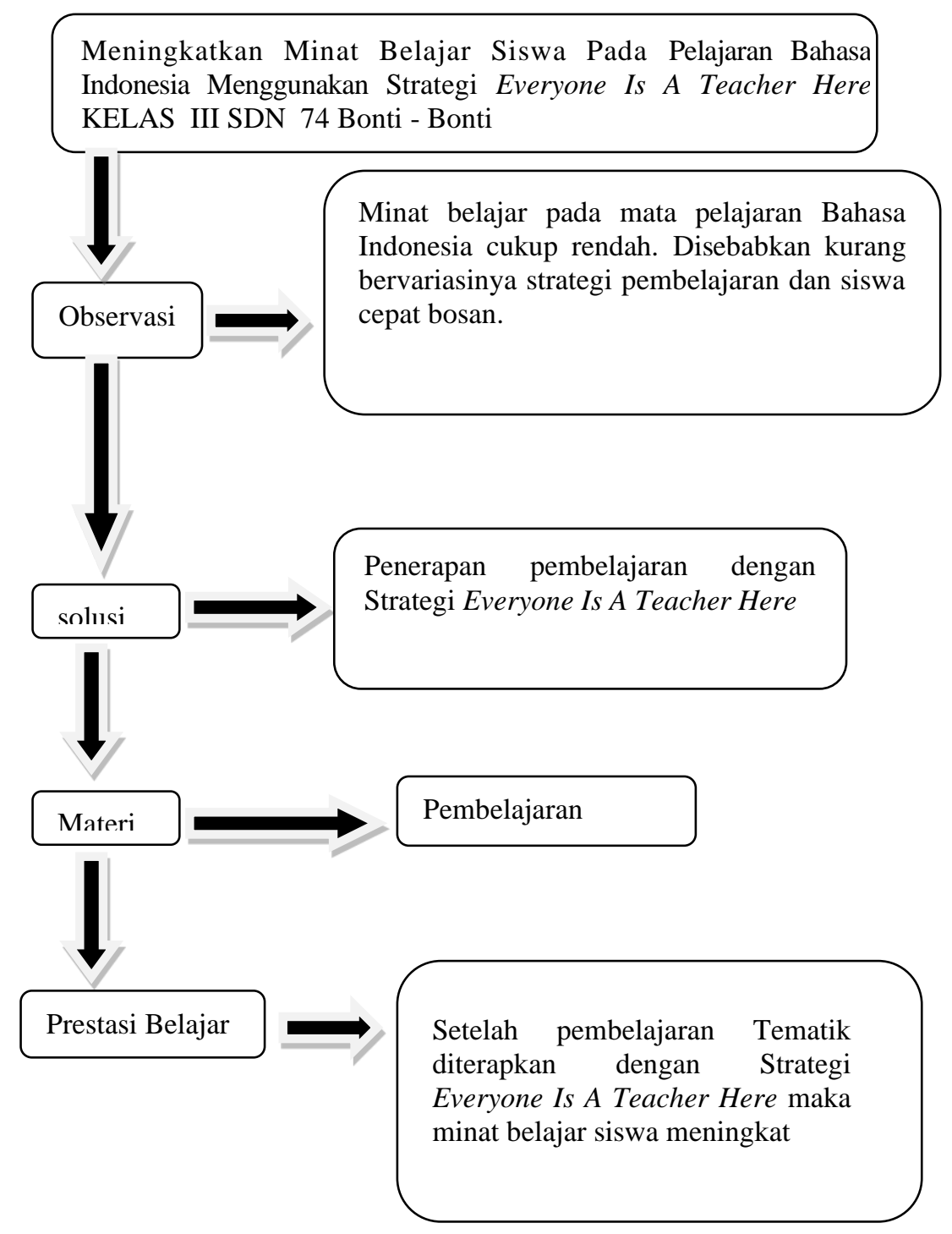

\section{Bagan 2.1 Kerangka Pikir}

\section{Hipotesis Tindakan.}

Berdasarkan kajian teori dan kerangka pikir diatas, maka hipotesis tindakan dalam penelitian ini adalah strategi pembelajaran Everyone Is A Teacher Here dapat minat belajar Bahasa Indonesia siswa kelas III SDN 74 Bonti - Bonti dapat meningkat. 


\section{BAB III}

\section{METODE PENELITIAN}

\section{A. Pendekatan dan Jenis Penelitian.}

\section{Pendekatan Penelitian.}

Pendekatan yang di gunakan dalam penelitian ini adalah pendekatan kualitatif. Dikatakan kualitatitaf karena data di peroleh melalui observasi, angket dan dokumentasi hasil belajar siswa dengan menggunakan Strategi pembelajaran Everyone Is A Teacher Here.

\section{Jenis Penelitian.}

Penelitian tindakan kelas merupakan suatu jenis penelitian yang dilakukan oleh guru untuk memecahkan masalah pembelajaran di kelasnya. Menurut Suharsimi dalam Daryanto (2018: 3) bahwa PTK merupakan paparan gabungan definisi dari tiga kata: Penelitian, tindakan, dan kelas. Penelitian adalah kegiatan mencermati suatu obyek, menggunakan aturan metodologi tertentu untuk memperoleh data atau informasi yang bermanfaat

bagi peneliti atau orang-orang yang berkepentingan dalam rangka peningkatan kualitas di berbagai bidang.

\section{B. Fokus penelitian.}

Fokus penelitian dalam penelitian ini ada dua yaitu:

1. Penerapan strategi pembelajaran Everyone Is A Teacher Here terhadap keaktifan siswa dalam kelas.

2. Minat belajar mata pelajaran Bahasa Indonesia 


\section{Setting dan Subjek Penelitian}

1. Setting Penelitian

Penelitian ini di laksanakan di kelas III SDN 74 Bonti - Bonti Kabupaten Maros penelitian ini di gunakan pada mata pelajaran Bahasa Indonesia semester I berdasarkan minat belajar siswa. Siklus penelitian ini di gunakan pada mata pelajaran Bahasa Indonesia semester I berdasarkan minat belajar siswa. Siklus penelitian ini terdiri atas perencanaan, tindakan, observasi dan refleksi yang dilakukan secara berulang-ulang sampai indikator pencapaian PTK tercapai.

2. Subjek Penelitian

Subjek penelitian ini adalah siswa kelas III SDN 74 Bonti - Bonti Kabupaten Maros tahun ajaran 2020/2021 dengan jumlah siswa 27 orang, yang terdiri dari laki-laki 16 orang dan perempuan 11 orang.

\section{Desain penelitian}

Penelitian tindakan kelas ini direncanakan sebanyak II siklus, Setiap siklusnya meliputi perencanaan, pelaksanaan, pengamatan, dan refleksi. Apabilah siklus I belum mencapai KKM yang ditentukan di lanjutkan ke siklus II. 
Desain penelitian tindakan kelas yang berdaur ulang, sebagai berikut:

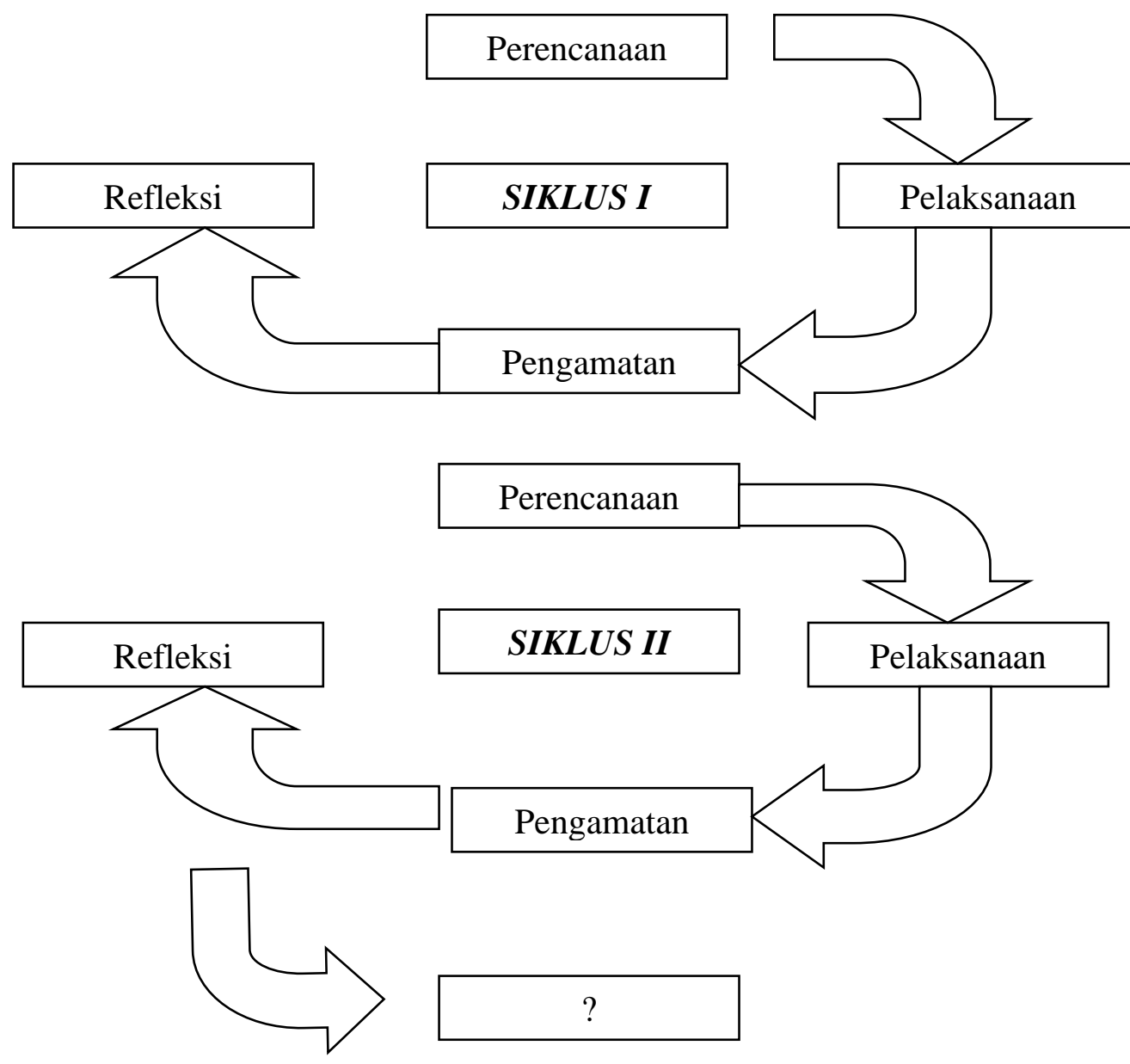

Bagan 3.1 Prosedur Penelitian

Sumber : Arikunto dalam Paizaluddin \& Ermalinda (2014: 34)

Tahapan-tahapan penelitian tindakan kelas sebagaimana yang dikemukakan oleh Suharsimi Arikunto di atas dapat diuraikan sebagai berikut:

1. Menyusun Rancangan Tindakan (Planing)

Dalam tahap ini menjelaskan tentang apa, mengapa, kapan, dimana, oleh siapa, dan bagaimana tindakan tersebut di lakukan. Secara umum langkahlangkah yang dilakukan pada tahap perencanaan adalah : 
a. Mengkaji silabus Bahasa Indonesia SD Kelas III untuk menyesuaikan waktu yang tersedia dalam silabus dengan waktu penelitian.

b. Membuat rencana pelaksanaan pembelajaran dengan menggunakan strategi pembelajaran Everyone Is A Teacher Here.

c. Membuat lembar kerja siswa.

d. Membuat instrumen yang digunakan dalam siklus PTK

e. Menyusun alat evaluasi pembelajaran

\section{Pelaksanaan Tindakan (Acting)}

Pelaksanaan Tindakan (Acting) yaitu praktek pembelajaran nyata berdasarkan rencana tindakan yang telah disusun bersama peneliti dan guru sebelumnya. Tindakan ini dimaksudkan untuk memperbaiki keadaan atau kegiatan pembelajaran di kelas yang belum sesuai dengan yang diharapkan. Adapun salah satu kegiatan yang dilaksanakan pada tahap ini adalah menyajikan materi pelajaran dengan menggunakan strategi pembelajaran Everyone Is A Teacher Here.

\section{Pengamatan (Observing)}

Tahap Pengamatan (Observing) adalah mengamati seluruh proses tindakan dan pada saat selesai tindakan. Fokus observasi adalah aktivitas guru dan siswa. Aktivitas guru dapat diamati mulai pada tahap pembelajaran, saat pembelajaran, dan akhir pembelajaran. Kegiatan observasi dilakukan secara kolaboratif antara guru dan teman sejawat. 


\section{Refleksi (Reflecting)}

Hasil observasi yang telah dilakukan dihasilkan kesimpulan sementara tentang pelaksanaan proses pembelajaran. Pada tahap refleksi ini dirumuskan kelebihan dan kekurangan-kekurangan dari proses pembelajaran yang dilakukan. Hasil kesimpulan tersebut kemudian direfleksi untuk menghasilkan tindakan perbaikan dan sebagai pertimbangan pada proses pelaksana siklus selanjutnya.

Keempat tahap dalam penelitian tindakan tersebut adalah unsur untuk membentuk siklus, yaitu satu putaran kegiatan yang terus bertahap yang kembali ke langkah awal. Jadi, satu siklus adalah dari tahap penyusunan rancangan sampai dengan refleksi yang tidak lain adalah evaluasi. Penelitian tindakan merupakan kegiatan yang pada ujungnya akan kembali ke langkah awal, yaitu dalam bentuk siklus. Peneliti menjalankan satu siklus itu tergantung dari seberapa luas materi yang diajarkan. Biasanya materi yang diajarkan hanya satu pokok bahasan, tetapi cukup luas sehingga memerlukan waktu beberapa kali pertemuan. Refleksi dapat dilaksanakan apabila peneliti sudah yakin mendapatkan pengalaman, dalam arti sudah memperoleh informasi yang perlu untuk memperbaiki cara yang telah dicoba. Jika pengamat telah mendapatkan informasi yang dibutuhkan sudah cukup sebagai masukan yang berarti untuk melaksanakan siklus selanjutnya.

Apabila letak keberhasilan dan hambatan telah di ketahui dari tindakan yang telah selesai dilaksanakan dalam satu siklus, guru pelaksana penelitian menyusun rancangan kembali untuk melanjutkan penelitian ke siklus kedua. Setelah menyusun rancangan untuk siklus kedua, guru dapat melanjutkan ke tahap ke 2, 3, dan 4 seperti yang terjadi pada siklus pertama. Jika telah melaksanakan 
siklus kedua dan guru masih merasa belum berhasil, guru dapat melanjukan ke siklus ketiga, yang cara dan tahapannya sama dengan siklus sebelumnya.

\section{E. Instrumen Penelitian.}

Instrumen yang peneliti gunakan dalam penelitian ini adalah pernyataanpernyataan yang dibentuk berupa angket, yang kemudian diberikan kepada objek penelitian. Selain angket peneliti juga menggunakan tes hasil belajar dengan memberikan pertanyaan-pertanyaan yang sesuai dengan proses pembelajaran. Selain angket dan tes, instrumen penelitian ini menggunakan observasi, dan dokumentasi untuk mendapatkan data yang di perlukan.

a. Observasi

Observasi atau pengamatan adalah tehnik pengumpulan data dengan cara mengamati setiap kejadian yang berlangsung dan mencatatnya dengan alat observasi tentang hal-hal yang akan diamati atau diteliti.

Observasi dalam penelitian yang berhubungan dengan kondisi kegiatan belajar mengajar, tingkah laku dan interaksi kelompok seperti dalam Penelitian Tindakan Kelas. Karena observasi merupakan sebuah proses pengamatan secara langsung.

b. Angket Minat

Angket minat adalah suatu teknik pengukuran yang di dalamnya terdapat berbagai pertanyaan, pernyataan, yang harus dijawab oleh respoden. Untuk mengukur ada atau tidaknya serta besarnya minat objek yang diteliti, digunakan angket Instrumen yang berupa angket ini dapat 
digunakan untuk mengetahui minat siswa tentang pembelajaran yang diterapkan.

c. Dokumentasi

Dokumentasi adalah untuk mendapatkan informasi dari responden. Pada teknik ini peneliti memungkinkan memperoleh informasi dari bermacam-macam sumber tertulis atau dokumen yang ada pada responden. Data yang diperoleh dari dokumen bisa digunakan untuk melengkapi bahkan memperkuat data dari hasil observasi, dan kemudian dianalisis dan ditafsirkan.

Teknik dokumentasi dilakukan melalui pengumpulan data tertulis dari sekolah mengenai data hasil belajar Bahasa6 Indonesia, jumlah siswa yang menjadi subyek penelitian, KKM mata pelajaran Bahasa Indonesia, dan proses kegiatan belajar mengajar yang berlangsung di kelas III SDN 74 Bonti - Bonti Kabupaten Maros.

\section{F. Teknik Pengumpulan data.}

Sugiyono (2015: 308) teknik pengumpulan data merupakan langkah yang paling utama dalam penelitian, karena tujuan utama dari penelitian adalah mendapatkan data. Teknik yang digunakan peneliti dalam mengumpulkan data adalah sebagai berikut :

1. Observasi

Observasi atau pengamatan adalah tehnik pengumpulan data dengan cara mengamati setiap kejadian yang berlangsung dan 
mencatatnya dengan alat observasi tentang hal-hal yang akan diamati atau diteliti.

Observasi dalam penelitian yang berhubungan dengan kondisi kegiatan belajar mengajar, tingkah laku dan interaksi kelompok seperti dalam Penelitian Tindakan Kelas. Karena observasi merupakan sebuah proses pengamatan secara langsung. Observasi yang dilakukan dalam penelitian ini yaitu pengamatnan akitivitas guru menggunakan lembar observasi guru.

2. Angket Minat

Angket adalah suatu teknik pengukuran yang di dalamnya terdapat berbagai pertanyaan, pernyataan yang harus dijawab oleh responden. Untuk mengukur ada atau tidaknya serta besarnya minat objek yang diteliti, digunakan angket. Instrumen yang berupa angket ini dapat digunakan untuk mengukur minat dan pendapat siswa mengenai stimulus pembelajaran yang sudah diberikan.

3. Dokumentasi

Dokumentasi adalah untuk mendapatkan informasi dari responden. Pada teknik ini peneliti memungkinkan memperoleh informasi dari bermacam-macam sumber tertulis atau dokumen yang ada pada responden. Data yang diperoleh dari dokumen bisa digunakan untuk melengkapi bahkan memperkuat data dari hasil observasi, dan kemudian dianalisis dan ditafsirkan. 
Teknik dokumentasi dilakukan melalui pengumpulan data tertulis dari sekolah mengenai data hasil belajar Bahasa Indonesia, jumlah siswa yang menjadi subyek penelitian, KKM mata pelajaran Bahasa Indonesia, dan proses kegiatan belajar mengajar yang berlangsung di kelas III SDN 74 Bonti - Bonti Kabupaten Maros.

\section{G. Teknik Analisis Data.}

Untuk menganalisis data yang diperoleh maka peneliti akan menggunakan data kualitatif yang diperoleh dari data aktivitas siswa, dimana siswa dibagi dalam beberapa kelompok. Dalam hal ini, data kualitatif menggunakan metode focus group discussion, dimana setiap kelompok diberi pertanyaan yang telah dibuat oleh peneliti sesuai dengan materi yang diberikan. Setiap siswa diamati minatnya secara klaksikal dalam setiap pertemuan dangan memberi skor pada lembar observasi yang telah disediakan sesuai dengan indicator yang telah ditentukan. Indikator siswa dikatakan aktif jika lebih dari atau sama dengan $75 \%$ frekuensi yang ditetapkan per-indikator dilakukan siswa. Setelah selesai diobservasi dihitung minat yang dimiliki siswa, lalu dipresentasikan. dapat membuat soal dari materi yang di ajarkan, menjawab pertanyaan yang didapat, dan mengerjakan tes akhir siklus yang diberikan guru. Menentukan persentase aktivitas yang dilakukan siswa dengan menggunakan rumus.

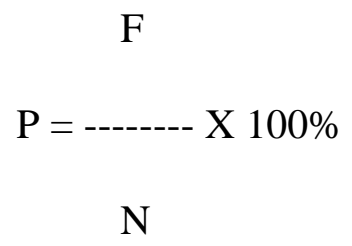


Keterangan: P : Angka persentase

$\mathrm{F}:$ Frekuensi minat siswa

$\mathrm{N}$ : Jumlah individu

(Sugiyono: 2015)

1. $81-100 \%$ adalah minat siswa sangat baik

2. $61-80 \%$ adalah minat siswa baik

3. $41-60 \%$ adalah minat siswa cukup

4. $21-40 \%$ adalah minat siswa kurang

5. 0 - $20 \%$ adalah minat siswa kurang sekali

\section{H. Indikator Keberhasilan.}

Penelitian tindakan kelas ini dinyatakan berhasil apabila adanya peningkatan minat belajar disetiap siklusnya. Dinyatakan berhasil jika minat siswa berada pada kategori baik dengan nilai minat $>80 \%$ secara klasikal dari jumlah keseluruhan siswa pada pembelajaran Bahasa Indonesia dalam menjalankan proses pembelajaran seperti memperhatikan penjelasan guru. 


\section{BAB IV}

\section{HASIL PENELITIAN DAN PEMBAHASAN}

\section{A. Hasil Penelitian}

Hasil penelitian yang dilakukan yaitu Penelitian Tindakan Kelas, dengan judul penelitian Penerapan Strategi Everyone Is A Teacher Here Dalam Meningkatkan Minat Belajar Bahasa Indonesia Pada Siswa Kelas III SD Negeri 74 Bonti - Bonti Kabupaten Maros yang berlokasi Jln. Mattoangin, Bantimurung, Kabupaten Maros, Sulawesi Selatan Data di peroleh melalui hasil observasi pada siklus I dan II untuk melihat aktivitas mengajar guru dan aktivitas belajar siswa serta meningkatnya minat belajar siswa di SD Negeri 74 Bonti - Bonti Subjek penelitian ini adalah siswa kelas III yang berjumlah 27 orang.

1. Pelaksanaan Siklus I

a. Perencanaan

Setelah diperoleh gambaran tentang keadaan kelas seperti perhatian, aktivitas, sikap, siswa saat mengikuti pelajaran, cara peneliti menyampaikan materi pelajaran dengan sumber belajar yang digunakan, keadaan tersebut dijadikan acuan dalam mengajarkan pembelajaran Bahasa Indonesia dengan menggunakan strategi Everyone is a teacher here. Rencana tindakan yang akan dilaksanakan adalah sebagai berikut.

1) Menentukan waktu pelaksanaan. 
2) Membuat Rencana Pelaksanaan Pembelajaran (RPP) dengan menggunakan Strategi Everyone is a teacher here. RPP disusun oleh peneliti dengan pertimbangan dari dosen dan guru. RPP dibuat sebagai acuan pembelajaran yang akan dilaksanakan.

3) Menyiapkan materi sesuai dengan langkah-langkah strategi pembelajaran Everyone is a teacher here.

4) Menyusun lembar observasi yang di dalamnya berisi lembar pengamatan tentang kegiatan guru dan siswa saat proses pembelajaran dengan menggunakan Strategi Everyone is a teacher here.

5) Menyusun soal-soal evaluasi.

6) Menyiapkan alat peraga dan sumber belajar yang akan digunakan dalam proses pembelajaran.

b. Pelaksanaan.

Penelitian pada siklus I dilaksanakan sebanyak tiga hari. pada hari rabu tanggal 2 September 2020 dengan durasi 3 x 35 menit, pukul 07.30-09.15 WITA, proses pembelajaran siklus I Pertemuan I dilaksanakan dengan materi ajar Pohon apel yang tulus Pada hari kamis tanggal 3 September 2020 pukul 07.30-09.15 WITA dilaksanakan proses pembelajaran Siklus I pertemuan II dengan materi ajar Pengembara dan Sebuah Pohon. Pertemuan ke III pada siklus I dilaksanakan evaluasi pada hari sabtu 5 September 2020. Strategi Everyone is a teacher here merupakan cara guru untuk meningkatkan minat belajar melalui partisipasi dan keaktifan siswa terhadap materi pelajaran. 
Materi yang diajarkan pada pertemuan pertama adalah Bumi. guru memulai pelajaran dengan salam pembuka, do'a bersama, dan apersepsi. Pada kegiatan apersepsi, guru menyampaikan materi tentang dongeng dan pesan moralnya. Guru juga menyampaikan tujuan pembelajaran sebagai berikut:

1) Siswa dapat menceritakan kembali isi dongeng dengan bahasa sendiri secara lisan, setelah menyimak teks dongeng yang dibacakan.

2) Siswa dapat menguraikan pesan dalam dongeng yang disajikan secara lisan, tulis, dan visual dengan tujuan.

3) Siswa dapat memeragakan pesan dalam dongeng sebagai bentuk ungkapan diri menggunakan kosa kata baku dan kalimat efektif

Setelah memberikan apersepsi, guru memberi arahan kepada siswa agar dapat memperhatikan penjelasan materi tentang dongeng yang dipaparkan oleh guru. Siswa memperhatikan penjelasan guru tentang materi dongeng. Setelah memaparkan materi, guru membagikan materi kepada siswa dan menjelaskan fungsi dari materi yang dibagikan.

Setelah guru selesai menceritakan salah satu dongeng yaitu Malin Kundang, guru memberikan kesempatan kepada siswa untuk membuat sebuah pertanyaan pada lembar LKS yang berasal dari materi yang dibagikan. Siswa membuat pertanyaan dengan bimbingan guru, diantaranya diarahkan ke karakter masing-masing tokoh dalam dongeng tersebut.

Setelah siswa selesai membuat pertanyaan, guru mengumpulkan pertanyaan itu dan mengacaknya kemudian membagikan kembali kepada siswa dan memberikan kesempatan kepada siswa untuk menjawab 
pertanyaan dari teman sekelasnya. Setelah selesai mengerjakan tugas, setiap siswa yang di tunjuk untuk maju mempresentasikan hasil kerjanya sementara siswa yang lain menyimak.

Selanjutnya guru memberikan penguatan tentang materi dan tugas yang telah dikerjakan serta memberikan motivasi dari pesan moral yang dapat dipetik dari dongeng Malin Kundang. Selanjutnya, siswa yang diberikan kesempatan untuk menanyakan materi yang belum jelas, berikutnya siswa dibimbing untuk membuat kesimpulan dari materi yang telah diajarkan.

Pada pertemuan II siklus I dilanjutkan materi yang telah dipelajari pada pertemuan pertama tentang dongeng. Pelajaran diawali dengan mengucapkan salam, kemudian menyampaikan topik yang akan dipelajari.

Guru membagikan beberapa judul dongeng kepada siswa. Siswa kemudian membaca dan memahami isi dan pesan moral yang dalam dongeng. materi tentang perubahan permukaan bumi akibat kegiatan manusia. Siswa diarahkan untuk menceritakan ulang dengan bahasa sendiri di depan kelas. Siswa yang lain diarahkan untuk membuat pertanyaan sesuai dongeng yang dipaparkan. Setelah beberapa siswa selesai maju bercerita, siswa diarahkan untuk membuat pertanyaan di selembar kertas dari salah satu dongeng tersebut dan menukar secara beracak kemudian dijawab.

Kegiatan terakhir yaitu, evaluasi angket dan evaluasi soal untuk melihat tingkah pencapaian minat belajar. Pengukuran minat belajar siswa dilakukan dengan memberikan angket sebanyak 30 butir pernyataan. 
Siswa mengerjakan angket dan soal evaluasi secara individu. Saat siswa sedang mengerjakan angket dan soal, guru berkeliling sambil memeriksa pekerjaan siswa. Setelah hasil evaluasi dikumpulkan, guru memberikan penguatan kepada siswa.

c. Observasi.

Tingkat keberhasilan tindakan pada siklus I ini diamati selama proses pelaksanaan. Fokus pengamatan adalah perilaku guru dan siswa selama proses pembelajaran berlangsung dengan menggunakan lembar observasi tindakan siklus I.

1) Hasil observasi aktivitas guru siklus I (pertemuan I dan II)

Pembelajaran tindakan siklus I diamati oleh guru kelas III SD Negeri 74 Bonti - Bonti . Adapun pelaksanaan tindakan siklus I yang diamati untuk guru disajikan pada tabel 4.1 berikut.

\section{Tabel 4.1 Data Hasil Observasi Aktivitas Mengajar Guru Siklus I}

\begin{tabular}{|l|c|c|c|c|}
\hline \multirow{2}{*}{\multicolumn{1}{|c|}{ Skor }} & \multicolumn{4}{c|}{ Siklus I } \\
\cline { 2 - 5 } & \multicolumn{2}{|c|}{ Pertemuan I } & \multicolumn{2}{c|}{ Pertemuan II } \\
\cline { 2 - 5 } & \multicolumn{2}{|c|}{ Nilai } & 4 & 20 \\
\hline Sangat Baik (5) & 1 & 5 & 4 & 4 \\
\hline Baik (4) & 1 & 4 & 1 & 2 \\
\hline Cukup (3) & 5 & 15 & 0 & 1 \\
\hline Kurang (2) & 3 & 6 & & 38 \\
\hline Kurang Sekali (1) & 0 & 0 & & $74 \%$ \\
\hline Total perolehan skor & & 30 & & Baik \\
\hline Presentasi & & $60 \%$ & & \\
\hline Kategori & & Cukup & & \\
\hline
\end{tabular}

Sumber: Lembar Observasi Guru Siklus I

Dari tabel 4.1 dapat disimpulkan pada pelaksanaan tindakan siklus I menunjukkan bahwa proses pelaksanaan pada siklus I di pertemuan I pembelajaran terlaksana dengan presentasi $60 \%$ dengan kategori cukup dan 
pertemuan II dengan presentasi $74 \%$ dengan kategori Baik. Hal ini menunjukan bahwa dalam penggunaan Strategi Everyone Is A Teacher Here guru belum melaksanakan dengan optimal karena masih adanya kendala yang terjadi pada saat pelaksanaan siklus I. Salah satu di antaranya yaitu guru masih terlihat kaku dalam mengajar, penggunaan waktu yang tidak sesuai dengan perangkat pembelajaran serta masih ada beberapa pelaksanaan kegiatan belajar yang belum terlaksana.

2) Hasil observasi aktivitas siswa siklus I (pertemuan I dan II)

Pengamatan aktivitas siswa digunakan pada lembar observasi untuk mencatat kejadian-kejadian yang terjadi selama proses belajar mengajar. Hasil observasi aktivitas pembelajaran siswa dengan menggunakan Strategi Everyone Is A Teacher Here. Siswa kelas III SD Negeri 74 Bonti - Bonti siklus I ditampilkan pada tabel berikut.

\section{Tabel 4.2 Data Hasil Observasi Aktivitas Belajar Siswa Siklus I}

\begin{tabular}{|l|c|c|}
\hline \multicolumn{1}{|c|}{ Indikator } & $\begin{array}{c}\text { Jumlah } \\
\text { Siswa }\end{array}$ & Skor \\
\hline Sangat Baik (5) & 5 & 25 \\
\hline Baik (4) & 7 & 28 \\
\hline Cukup (3) & 6 & 18 \\
\hline Kurang (2) & 8 & 16 \\
\hline Kurang Sekali (1) & 1 & 1 \\
\hline Total perolehan skor & & 88 \\
\hline Presentasi & & $60 \%$ \\
\hline Kategori & & Cukup \\
\hline
\end{tabular}

Sumber: Lembar Observasi Aktivitas Belajar Siswa

Berdasarkan tabel hasil observasi 4.2, maka dapat disimpulkan bahwa pada pertemuan siklus I mencapai nilai presentasi $60 \%$ di kategorikan cukup, dari hasil tersebut perlu adanya evaluasi dan perubahan lagi dalam proses pembelajaran. Salah satu penyebabnya karena masih beberapa siswa yang 
kurang memperhatikan pada saat mengikuti proses pembelajaran. Hal ini terlihat dari perilaku siswa dalam kegiatan belajar mengajar masih ada siswa yang tidak terlibat dalam proses pembelajaran.

3) Hasil Minat Belajar Siswa.

Hasil minat belajar siswa pada mata pelajaran Bahasa Indonesia sebanyak 27 siswa pada siklus I telah menunjukan minat terhadap mata pelajaran Bahasa Indonesia. Adapun nilai yang diperoleh disajikan pada tabel 4.3 sebagai berikut.

Tabel 4.3 Distribusi Frekuensi dan Presentasi Minat Belajar Bahasa Indonesia Siklus I

\begin{tabular}{|l|c|c|}
\hline \multicolumn{1}{|c|}{ Indikator } & $\begin{array}{c}\text { Jumlah } \\
\text { Siswa }\end{array}$ & Skor \\
\hline Sangat Berminat(5) & 3 & 15 \\
\hline Berminat (4) & 10 & 40 \\
\hline Cukup (3) & 12 & 36 \\
\hline Kurang Berminat(2) & 2 & 4 \\
\hline Sangat Kurang Berminat (1) & 0 & 0 \\
\hline Total perolehan skor & & 95 \\
\hline Presentasi & & $70 \%$ \\
\hline Kategori & & Baik \\
\hline
\end{tabular}

Sumber: Nilai Angket Siklus I

Dari tabel distribusi 4.3 yang di paparkan di atas hasil nilai angket rata-rata siswa menjawab pada kategori sangat baik (81-100) sebanyak 3 siswa . Pada kategori baik (61-80) dengan jumlah siswa 10. Begitu pula dengan kategori cukup terdapat 12 siswa. Sebanyak 2 siswa masuk dalam kategori kurang baik. Artinya minat siswa telah belum mencapai indikator kebrhasilan penelitan (>80\%) Sedangkan masih ada 2 orang siswa yang kurang berminat belajar Bahasa Indonesia. 
d. Refleksi.

Hasil refleksi dari obeservasi menunjukan bahwa pembelajaran siklus I belum maksimal. Observer bersama guru melakukan evaluasi pelaksanaan pembelajaran untuk diperbaiki pada siklus berikutnya. Evaluasi juga dilakukan dengan siswa terkait dengan pelajaran sebelumnya agar mengetahui penyebab masih adanya siswa yang kurang memahami pembelajaran Bahasa Indonesia dengan menggunakan Strategi Everyone Is A Teacher Here. Observer dan guru mendiskusikan agar kegiatan pada pertemuan berikutnya dapat lebih meningkat minat belajar siswa secara merata. Menentukan rancangan kegiatan pembelajaran yang lebih menyenangkan melalui Strategi Everyone Is A Teacher Here dengan konsep yang baru. Secara umum berdasarakan data hasil observasi pada siklus I, kendala dan penyebab dalam pelaksanaan pembelajaran yaitu guru masih kaku dalam mengajar menggunakan strategi pembelajaran yang baru dan siswa masih kurang paham dengan strategi yang baru serta tidak memperhatikan penjelasan guru.

\section{Pelaksanaan Siklus II}

Pembelajaran pada siklus I memberikan gambaran, bahwa presentasi minat belajar siswa telah mencapai KKM. Namun aktivitas belajar siswa masih berada pada kategori cukup dengan presentasi $60 \%$. Sesuai dengan hasil refleksi pada siklus I, maka perlu diadakan tindakan selanjutnya yaitu siklus II, dengan tujuan agar aktivitas belajar yang diperoleh siswa dapat memenuhi kriteria keberhasilan dan minat belajar siswa lebih 
meningkat secara merata. Materi yang akan diajarkan pada siklus II ini adalah mengidentifikasi lambang/ simbol (rambu lalu lintas, pramuka, dan lambang negara) beserta artinya dalam teks lisan, tulis, visual, dan/atau eksplorasi lingkungan. Kegiatan yang dilaksanakan pada siklus II antara lain.

\section{a. Perencanaan}

Tahap pertama yang dilakukan dalam siklus II ini adalah penyempurnaan proses pembelajaran dari siklus I yang di awali dengan perencanaan tindakan. Guru menyusun perbaikan pembelajaran yang akan dilaksanakan pada siklus II. Perencanaan tindakan pada siklus II adalah sebagai berikut.

1) Menentukan waktu pelaksanaan.

2) Menentukan materi Bahasa Indonesia yang akan diajarkan pada siswa sesuai dengan pemetaan kompetensi dasar (KD), yaitu mengidentifikasi lambang/ simbol (rambu lalu lintas, pramuka, dan lambang negara) beserta artinya dalam teks lisan, tulis, visual, dan/atau eksplorasi lingkungan.

3) Membuat Rencana Pelaksanaan Pembelajaran (RPP) dengan menggunakan Strategi Everyone is a teacher here. RPP disusun oleh guru dengan pertimbangan dari dosen dan Wali Observer. RPP dibuat sebagai acuan pembelajaran yang akan dilaksanakan.

4) Menyiapkan materi sesuai dengan langkah-langkah strategi Everyone is a teacher here. 
5) Menyusun lembar observasi yang di dalamnya berisi lembar pengamatan tentang kegiatan guru dan siswa saat proses pembelajaran dengan menggunakan Strategi Pembelajaran Everyone is a teachere here.

6) Menyusun soal-soal evaluasi.

7) Menyiapkan alat peraga dan sumber belajar yang akan digunakan dalam proses pembelajaran.

b. Pelaksanaan

Pertemuan pertama pada siklus II dilaksanakan pada hari senin, 7 September 2020 pada pukul 07.30-09.15 dengan alokasi waktu 3 x 35 menit. Pertemuan I siklus II melaksanakan proses belajar mengajar dengan materi mengidentifikasi lambang/ simbol (rambu lalu lintas, pramuka, dan lambang negara) beserta artinya dalam teks lisan, tulis, visual, dan/atau eksplorasi lingkungan. Pertemuan kedua dilaksanakan pada hari Selasa, 8 September 2020 pukul 07.30-09.15 dengan alokasi waktu 3 x 35 menit Materi yang diajarkan yaitu lanjutan dari pertemuan pertama sekaligus membagikan angket dan evaluasi siklus II.

Guru memulai pelajaran dengan salam pembuka, do'a bersama, dan absensi, selanjutnya guru menyampaikan tujuan yang akan dipelajari. Untuk mengawali pelajaran, guru melakukan apersepsi. Guru kemudian menjelaskan tujuan pembelajaran yang akan dilaksanakan yaitu, mengidentifikasi lambang/ simbol (rambu lalu lintas, pramuka, dan lambang 
negara) beserta artinya dalam teks lisan, tulis, visual, dan/atau eksplorasi lingkungan.

Setelah memberikan apersepsi, guru memberi arahan kepada siswa agar dapat memperhatikan penjelasan materi tentang peristiwa alam di Indonesia yang dipaparkan oleh guru. Siswa memperhatikan penjelasan guru tentang materi mengidentifikasi lambang/ simbol (rambu lalu lintas, pramuka, dan lambang negara) beserta artinya dalam teks lisan, tulis, visual, dan/atau eksplorasi lingkungan. Setelah memaparkan materi, guru membagikan materi kepada siswa dan menjelaskan fungsi dari materi yang dibagikan.

Setelah siswa selesai membaca dan memahami materi yang dibagikan, guru memberikan kesempatan kepada siswa untuk membuat sebuah pertanyaan pada lembar LKS yang berasal dari materi yang dibagikan. Siswa nampak antusias membuat pertanyaan dengan bimbingan guru.

Setelah siswa selesai membuat pertanyaan, guru mengumpulkan pertanyaan itu dan mengacaknya kemudian membagikan kembali kepada siswa dan memberikan kesempatan kepada siswa untuk menjawab pertanyaan dari teman sekelasnya. Setelah selesai mengerjakan tugas, setiap siswa yang di tunjuk untuk maju mempresentasikan hasil kerjanya sementara siswa yang lain menyimak.

Selanjutnya guru memberikan penguatan tentang materi dan tugas yang telah dikerjakan serta memberikan motivasi kepada siswa untuk 
belajar lebih rajin belajar. Selanjutnya, siswa yang diberikan kesempatan untuk menanyakan materi yang belum jelas, berikutnya siswa dibimbing untuk membuat kesimpulan dari materi yang telah diajarkan.

Pada pertemuan II siklus II dilanjutkan materi yang telah dipelajari pada pertemuan pertama tentang lambang/ simbol (rambu lalu lintas, pramuka, dan lambang negara) beserta artinya dalam teks lisan, tulis, visual, dan/atau eksplorasi lingkungan. Pelajaran diawali dengan mengucapkan salam, kemudian menyampaikan topik yang akan dipelajari.

Siswa memperhatikan penjelasan tentang materi. Guru membagikan materi kepada siswa, Setelah siswa membaca materi tersebut siswa diarahkan untuk membuat pertanyaan sesuai topik yang di pelajari tentang lambang/ simbol (rambu lalu lintas, pramuka, dan lambang negara) beserta artinya dalam teks lisan, tulis, visual, dan/atau eksplorasi lingkungan. Setelah itu, siswa diarahkan untuk membuat perntanyaan dan menjawab pertnyaan tersebut secara beracak.

Evaluasi angket dan evaluasi soal untuk melihat tingkah pencapaian minat belajar siswa dan hasil belajar siswa. Pengukuran minat belajar siswa dilakukan dengan memberikan angket sebanyak 30 butir pernyataan, untuk membuktikan minat belajar siswa meningkat di tandai dengan hasil belajar siswa meningkat dari siklus I berupa pilihan ganda sebanyak 10 butir soal kepada siswa. Siswa mengerjakan angket dan soal evaluasi secara individu. Saat siswa sedang mengerjakan angket dan soal, guru berkeliling sambil memeriksa pekerjaan siswa. Setelah hasil evaluasi 
dikumpulkan, guru memberikan penguatan kepada siswa agar lebih rajin belajar di rumah.

c. Observasi

Pelaksanaan siklus II tetap sama dengan pelaksanaan pada siklus sebelumnya yaitu observasi terhadap aktivitas proses belajar mengajar guru.

a) Data hasil observasi guru siklus II

Berdasarkan pengamatan observer, data hasil observasi aktivitas mengajar guru disajikan dalam tabel berikut.

Tabel 4.4 Data Hasil Observasi Aktivitas Mengajar Guru Siklus II

\begin{tabular}{|l|c|c|c|c|}
\hline \multirow{2}{*}{\multicolumn{1}{|c|}{ Skor }} & \multicolumn{4}{c|}{ Siklus II } \\
\cline { 2 - 5 } & \multicolumn{2}{|c|}{ Pertemuan I } & \multicolumn{2}{c|}{ Pertemuan II } \\
\cline { 2 - 5 } & \multicolumn{2}{|c|}{ Nilai } & 4 & 20 \\
\hline Sangat Baik (5) & 3 & 15 & 3 & 12 \\
\hline Baik (4) & 5 & 20 & 2 & 6 \\
\hline Cukup (3) & 2 & 6 & 0 & 0 \\
\hline Kurang (2) & 0 & 0 & 0 & 38 \\
\hline Kurang Sekali (1) & 0 & 0 & & $80 \%$ \\
\hline Total perolehan skor & & 41 & & Baik \\
\hline Presentasi & & $82 \%$ & & \\
\hline Kategori & & $\begin{array}{c}\text { Sangat } \\
\text { Baik }\end{array}$ & & \\
\hline
\end{tabular}

Sumber: Lembar Observasi Guru Siklus II

Dari tabel 4.6 dapat disimpulkan bahwa pada pelaksanaan tindakan siklus II pertemuan I menunjukan proses pembelajaran berada pada kategori sangat baik dengan presentasi $82 \%$ dan pada pertemuan II menunjukkan proses pembelajaran terlaksana dengan kategori sangat baik dengan presentasi $80 \%$. Hal ini menunjukan bahwa dalam proses pembelajaran guru telah menggunakan strategi Everyone Is A Teacher Here, dengan baik dan mengaplikasikan pembelajaran yang mengatifkan keterlibatan siswa dan meningkatkan minat belajar siswa. Guru sudah mampu menyesuaikan waktu 
kegiatan dengan waktu yang telah di tentukan di perangkat pembelajaran, guru telah melaksanakan kegiatan pembelajaran dengan efektif. Pada siklus II ini kurangnya kendala yang di alami guru maka dapat di simpulkan guru telah melaksanakan kegiatan sesuai dengan RPP dan menggunakan Strategi Everyone Is A Teacher Here, pada proses pembelajaran.

b) Data hasil observasi siswa siklus II

Tabel 4.5 Data Hasil Observasi Aktivitas Belajar Siswa Siklus II

\begin{tabular}{|l|c|c|}
\hline \multicolumn{1}{|c|}{ Indikator } & $\begin{array}{c}\text { Jumlah } \\
\text { Siswa }\end{array}$ & Skor \\
\hline Sangat Baik (5) & 11 & 55 \\
\hline Baik (4) & 8 & 32 \\
\hline Cukup (3) & 8 & 24 \\
\hline Kurang (2) & 0 & 0 \\
\hline Kurang Sekali (1) & 0 & 0 \\
\hline Total perolehan skor & & 111 \\
\hline Presentasi & & $82 \%$ \\
\hline Kategori & & Sangat Baik \\
\hline
\end{tabular}

Sumber: Lembar Observasi Siswa Siklus II

Dari tabel di atas dapat disimpulkan bahwa pada pelaksanaan tindakan siklus II pada pertemuan I telah mencapai kategori sangat baik dengan presentasi $82 \%$. Hasil observasi menunjukkan bahwa pembelajaran dengan menggunakan Strategi Everyone Is A Teacher Here sudah berjalan semakin baik, guru sudah bisa mengarahkan siswa untuk membuat soal dengan mandiri dan melakukan berbagai kegiatan pembelajaran. Hasil observasi terhadap siswa pada siklus II menunjukan bahwa sudah terlihat keseriusan siswa dalam belajar dan siswa terlibat lagsung dalam pembelajaran. 
c) Hasil Minat Belajar siswa.

Hasil minat belajar siswa pada mata pelajaran Bahasa Indonesia sebanyak 32 orang pada siklus II semakin menunjukan minat terhadap mata pelajaran Bahasa Indonesia. Hal ini di tunjukan dengan tidak adanya siswa yang berada pada kategori kurang berminat atau sangat kurang berminat. Adapun nilai yang diperoleh disajikan pada tabel 4.8 sebagai berikut.

Tabel 4.6 Distribusi Frekuensi dan Presentasi Minat Belajar Bahasa Indonesia Siklus II

\begin{tabular}{|l|c|c|}
\hline \multicolumn{1}{|c|}{ Indikator } & $\begin{array}{c}\text { Jumlah } \\
\text { Siswa }\end{array}$ & Skor \\
\hline Sangat Berminat(5) & 10 & 50 \\
\hline Berminat (4) & 10 & 40 \\
\hline Cukup (3) & 7 & 21 \\
\hline Kurang Berminat(2) & 0 & 0 \\
\hline Sangat Kurang Berminat (1) & 0 & 0 \\
\hline Total perolehan skor & & 111 \\
\hline Presentasi & & $82 \%$ \\
\hline Kategori & & Sangat Baik \\
\hline
\end{tabular}

Sumber: Nilai Angket Siklus II

Berdasarkan tabel distribusi 4.8 yang di paparkan di atas hasil nilai angket siswa mayoritas menjawab dengan pilihan sangat baik berjumlah 10 siswa. Siswa yang menjawab dengan kategori baik berjumlah 10 siswa., sisanya 7 siswa menjawab dengan kategori cukup. Minat siswa terhadap pembelajaran Bahasa Indonesia dengan menggunakan stretegi Everyone Is A Teacher Here pada siklus II mengalami peningkatan dibandingkan dengan siklus I. Pada siklus II minat siswa telah memenuhi ambang batas minimal keberhasilan penenlitian, yaitu $>80 \%$ sedangkan presentase minat belajar siswa $82 \%$. 


\section{d. Refleksi}

Secara umum, pelaksanaan tindakan pada siklus II tidak ditemukan kendala yang cukup serius, karena pelaksanaan siklus II merupakan perbaikan dari saran-saran yang dikemukakan pada siklus I serta hasil diskusi dengan observer sebagai kolaborator. Berdasarkan hasil refleksi pada siklus II, dapat dikatakan bahwa hampir setiap langkah dalam rencana pelaksanaan pembelajaran (RPP) yang telah disusun sudah terlaksana dengan baik. Aspek-aspek yang diamati dalam pembelajaran dengan menggunakan Strategi Everyone Is A Teacher Here juga sudah terpenuhi, meskipun di dalamnya masih ada yang belum sempurna.

Pada dasarnya penggunaan Strategi Everyone Is A Teacher Here dalam pembelajaran Bahasa Indonesia dapat meningkatkan minat belajar siswa, dan rasa ingin tahu serta keaktifan siswa pada kelas III SD Negeri 74 Bonti - Bonti.

\section{B. Pembahasan}

Penelitian ini menggunakan dua siklus, pada setiap siklusnya terdapat 3 kali pertemuan. Adapun yang dilakukan pada siklus I dan II untuk meningkatkan minat belajar Bahasa Indonesia dengan menggunakan Strategi Everyone Is A Teacher Here pada kelas III SD Negeri 74 Bonti Bonti. Menurut Hidayatun Nisa' dalam penelitiannya tahun 2018, dengan judul Penggunaan Strategi Everyone Is A Teacher Here terhadap minat belajar matematikan kelas $5 \mathrm{SDN}$ kemantren. Strategi Everyone Is A Teacher Here dapat meningkatkan minat belajar siswa dari siklus I ke siklus 
II. Penelitian ini menjadi sala satu acuan penulis dalam melakukan penelitian.

Minat belajar siswa sangat terkait dengan kepribadian, motivasi, ekspresi dan konsep diri atau identifikasi, faktor keturunan dan pengaruh eksternal atau lingkungan (Susanto 2013: 57). Minat timbul apabila indvidu tertarik kepada suatu hal yang mereka anggap penting bagi dirinya dan dapat memenuhi kebutuhan yang mereka inginkan.

Hasil siklus I menunjukkan bahwa nilai angket rata-rata kelas berada pada kategori Baik (85\%) dan sisanya 4 siswa (15\%) menunjukkan minat yang rendah, yang berarti hasil angket siswa telah menunjukan bahwa minat belajar siswa telah ada. Namun tidak di tandai dengan hasil observasi aktivitas siswa yang masih pada kategori cukup dengan presentasi $60 \%$.. Oleh karena itu, peneliti melaksanakan observasi kembali pada siklus II, jika pada minat belajar siswa meningkat apakah hasil observasi aktivitas siswa meningkat.

Setelah dilakukan refleksi pada siklus I, maka dilakukan perbaikan Pada Siklus II, dengan beberapa kegiatan yang lebih dimaksimalkan dalam pelaksanaannya, seperti lebih memaksimal penerapan Strategi Everyone Is A Teacher Here dan guru lebih menyiapkan diri agar dalam menyampaikan materi kepada siswa dapat lebih maksimal.

Pada siklus II minat belajar telah meningkat jika dibandingkan dengan siklus I. Hal ini ditunjukkan oleh peningkatan hasil angket dengan 15 siswa menjawab sangat berminat $(55,6 \%)$ dan tidak ada siswa yang memberikan 
jawaban pada kategori dibawah cukup. Aktivitas belajar siswa dari mengalami peningkatan menjadi baik $(80 \%)$. Materi Bahasa Indonesia yang diajarkan kepada siswa adalah contoh nyata dalam kehidupan sehari-hari, sehingga pada proses pembelajaran semua materi dikaitkan dengan kehidupan sehari-hari dan sering dialami siswa, dengan demikian penerapan Strategi Everyone Is A Teacher Here dapat meningkatkan minat belajar melalui hasil angket dan observasi Aktivitas siswa mata pelajaran Bahasa Indonesia pada siswa kelas III SD Negeri 74 Bonti - Bonti. 


\section{BAB V}

\section{KESIMPULAN DAN SARAN}

\section{A. Kesimpulan}

Berdasarkan hasil penelitian dan pembahasan dapat di simpulkan bahwa dengan menggunakan Strategi Everyone Is A Teacher Here dapat meningkatkan minat belajar Bahasa Indonesia pada siswa kelas III SD Negeri 74 Bonti - Bonti. Hal ini dapat dilihat aktivitas siswa pada siklus I yaitu 60 yang masuk kategori cukup dan siklus II dengan nilai 82 dengan kategori baik. Hasil yang didapatkan pada siklus I terdapat minat belajar dengan nilai rata-rata kelas 70 berada pada kategori baik namun masih banyak siswa yang minatnya rendah dan belum mencapai target penelitian. Sedangkan pada siklus II terdapat minat belajar berada di kategori sangat baik dengan nilai 82 . Sehingga dapat dilihat peningkatan minat belajar siswa pada siklus II yang mengalami peningkatan yang signifikan dan memenuhi ambang batas keberhasilan penelitian (>80\%).

\section{B. Saran}

Berdasarkan hasil penelitian dan pembahasan di atas, disarankan hal-hal sebagai berikut.

1. Bagi siswa, minat baik yang sudah dicapai harus dipertahankan dan hendaknya siswa lebih aktif dalam mengikuti pelajaran Bahasa Indonesia.

2. Bagi guru, pembelajaran Bahasa Indonesia dengan menggunakan Strategi Everyone Is A Teacher Here bukan semata-mata 
menghadirkan dunia nyata siswa ke dalam kelas. Guru dituntut untuk lebih kreatif dalam memvariasikan strategi pembelajaran, membimbing siswa untuk lebih aktif dalam memberikan umpan balik, membangkitkan minat belajar dan rasa ingin tahu, serta mengarahkan siswa untuk lebih aktif dalam pembelajarandan berdiskusi kelompok.

3. Bagi sekolah, pada umumnya guru kelas banyak yang belum mengetahui tentang Strategi Everyone Is A Teacher Here, sehingga masih sangat sedikit diterapkan dalam pembelajaran. Sebaiknya sekolah mengadakan pelatihan terhadap guru-guru kelas mengenai strategi-strategi pembelajaran.

4. Bagi guru lain, guru lain yang tertarik untuk melakukan Penelitian dengan menggunakan Strategi Everyone Is A Teacher Here, diharapkan dapat melakukan Penelitian lebih lanjut tentang aspekaspek lain dalam pembelajaran Bahasa Indonesia dengan menggunakan Strategi Everyone Is A Teacher Here dan dapat mengaplikasikannya pada pokok bahasan yang berbeda. 


\section{DAFTAR PUSTAKA}

Almairah. 2019. Pengaruh media gambar terhadap hasil belajar bahasa Indonesia kelas V SD Inpres Perumnas Antang II/I Kota Makassar. Skripsi. Tidak di Terbitkan. Universitas Megarezky. Makassar.

Ahmad, Susanto. (2013). Teori Belajar dan Pembelajaran di Sekolah Dasar. Jakarta: Kencana Prenada Media Group

Daryanto. 2018. Penelitian Tindakan Kelas Dan Penelitian Tindakan Sekolah. Yogakarta: Gava Media.

Dimyanti \& Mudjiono. 2015. Belajar dan Pembelajaran. Jakarta: PT. Rineka Cipta.

Fathurrohman, Muhammad. 2017. Model-model Pembelajaran Inovatif. Jogjakarta: AR-Ruzz Media.

Ghony Djunaidi. M \& Almanshur Fauzan. (2017). Metodologi Penelitian Kualitatif. Jogjakarta: Ar-Ruz Media.

Haryanto, Warsono. 2017. Pembelajaran Aktif. Bandung: PT Remaja Rosdakarya

Husain, Siti. 2019. Upaya Meningkatkan Hasil Belajar Siswa Kelas V Melalui Model Pembelajaran Course Review Horay (CRH) Mata pelajaran IPS SD Inpres Bangkala III Kecamatan Manggala Kota Makassar. Skripsi. Universitas Megarezky. Makassar.

Hidayat, Isnu. 2019. 50 Strategi Pembelajaran Populer. Yokyakarta: DVA Press

Iskandarwassid, Dadang Sunendar. 2010. Strategi Pembelajaran Bahasa. Bandung: PT Remaja Rosdakarya

Kadir, Abdul. 2014. Dasar-Dasar Pendidikan. Jakarta: Kharisma Putra Utama

Kompri, 2015. Motivasi Pembelajaran Perspektif guru dan siswa. Bandung: PT Remaja Roosdakarya.

Nisa, Hidayatun. 2018. Penggunaan Strategi Everyone Is A Teacher Here Terhadap Minat Belajar Matematika kelas 5. Skripsi. Diterbitkan. Pendidikan Guru Sekolah Dasar, Universitas Muhammadiyah Sidoarjo.

Paizaluddin \& Ermalinda. 2016. Penelitian Tindakan Kelas.Bandung: Alfabeta Purwanto. 2010. Evaluasi Hasil belajar. Yogyakarta: Pustaka Pelajar. 
Riwahyudin, Arvi. 2015. Sikap Siswa Dan Minat Belajar Siswa Terhadap Hasil Belajar Ipa Siswa Kelas V Sekolah Dasar Di Kabupaten Lamandau. Jurnal pendidikan dasar. $6: 11$

Setyaningtyas, Ermina Johana dkk.2018. Peningkatan KreatVitas Dan Hasil Belajar Mata Pelajaran IPA Menggunakan Model Pembelajaran Quantum Teaching Pada Siswa Kelas 2.Jurnal Mitra Pendidikan (JMP Online).2(6): 532-533.

Sholihah, Mar'atus. 2018. Pengaruh Strategi Pembelajaran Aktif Tipe Everyone Is A Teacher Here Terhadap Hasil Belajar Ipa Siswa Kelas V SD Negeri 3 Metro Pusat. Skipsi. Ditrbitkan. Fakultas KEGURUAN Dan Ilmu Pendidikan UnVersitas Lampung. .

Sugiyono. 2015. Metode Penelitian Kuantitatif, Kualitatif, dan R\&G. Bandung: Alfabeta.

Slameto. 2010. Belajar dan faktor-faktor yang Mempengaruhinya. Jakarta: PT. Rineka Cipta

Sriyanti, Lilik. Psikologi Belajar. Yogyakarta: Penerbit Ombak, 2013.

Syahruddin. 2018. Pengaruh Strategi Everyone Is A Teacher Here (Eth), ontextual Teaching And Learning (Ctl), Dan Crossword Puzzle (Cwp) Serta Motivasi Belajar Terhadap Hasil Belajar Siswa Pada Mata Pelajaran Bahasa Arab di Mts Darul Falah Aek Songsongan. Jurnal Analitica Islamica. $7: 65-66$

Undang-Undang Republik Indonesia Nomor 20 Tahun 2003 Tentang Sistem Pendidikan Nasional. Jakarta: Sinar Grafika. 


$$
\text { L }
$$

A

M

P

I

R

A

$\mathbf{N}$ 


\section{LAMPIRAN I}

\section{RPP SIKLUS I DAN SIKLUS II}




\section{RENCANA PELAKSANAAN PEMBELAJARAN (RPP)}

\section{SIKLUS I PERTEMUAN 1}

Sekolah : SD NEGERI 74 BONTI - BONTI

Mata pelajaran : Bahasa Indonesia

Kelas/semester $\quad$ : III / I

Waktu : $3 \times 35$ menit

\section{A. Kompetensi Inti}

KI 1 : Menerima, menjalankan dan menghargai ajaran agama yang dianutnya.

KI 2 : Memiliki perilaku jujur, disiplin, tanggung jawab, santun, peduli, dan percaya diri dalam berinteraksi dengan keluarga, teman, guru, dan tetangganya.

KI 3 : Memahami pengetahuan faktual dengan cara mengamati (mendengar, melihat, membaca dan menanya) dan menanya berdasarkan rasa ingin tahu tentang dirinya, makhluk ciptaan Tuhan dan kegiatannya, dan benda-benda yang dijumpainya di rumah, sekolah, dan tempat bermain.

KI 4 : Menyajikan pengetahuan faktual dalam bahasa yang jelas, sistematis, dan logis, dalam karya yang estetis, dalam gerakan yang mencerminkan anak sehat, dan dalam tindakan yang mencerminkan peri-laku anak beriman dan berakhlak mulia.

\section{B. Kompetensi Dasar}

3.8 Menguraikan pesan dalam dongeng yang disajikan secara lisan, tulis, dan visual dengan tujuan untuk kesenangan.

4.8 Memeragakan pesan dalam dongeng sebagai bentuk ungkapan diri menggunakan kosa kata baku dan kalimat efektif

\section{Indikator}

3.8.1 Membaca dongeng dengan lafal, intonasi, dan ekspresi.

4.8.1 Mengidentifikasi informasi isi dongeng yang didengar. 


\section{Tujuan Pembelajaran}

Setelah Mendengarkan penjelasan guru, siswa dapat :

1. Dengan memperhatikan tanda baca, siswa dapat membaca dongeng dengan lafal, intonasi, dan ekspresi yang tepat.

2. Dengan menjawab pertanyaan, siswa dapat mengidentifikasi informasi isi dongeng yang didengar dengan tepat.

E. Materi Pokok

Dongeng "Pohon apel yang tulus"

F. Karakter siswa yang diharapkan :

1. Disiplin

2. Tanggung jawab

3. Ketelitian .

\section{G. Pendekatan, Strategi, Media dan Metode Pembelajaran}

Pendekatan : Saintific

Strategi : Everyone Is A Teachere Here

Metode $\quad$ : Ceramah dan Diskusi 


\section{H. Langkah-langkah Pembelajaran}

\begin{tabular}{|c|c|c|c|}
\hline No & Kegiatan & Deskripsi & $\begin{array}{l}\text { Alokasi } \\
\text { Waktu }\end{array}$ \\
\hline 1. & $\begin{array}{c}\text { Kegiatan } \\
\text { Pendahuluan }\end{array}$ & $\begin{array}{l}\text { 1. Guru masuk kelas dengan } \\
\text { mengucapkan salam kepada siswa } \\
\text { dan menayakan kabar siswa. } \\
\text { 2. Guru meminta salah satu siswa } \\
\text { untuk memimpin doa. } \\
\text { 3. Guru mengkondisikan kelas dan } \\
\text { memeriksa kehadiran siswa. }\end{array}$ & 10 Menit \\
\hline 2. & Kegiatan Inti & $\begin{array}{l}\text { 1. Guru menyampaikan tujuan } \\
\text { pembelajaran dan memotifasi siswa. } \\
\text { 2. Guru menunjukan media gambar } \\
\text { kepada siswa. } \\
\text { 3. Guru menjelaskan materi dongeng } \\
\text { tentang pohon apel yang tulusu } \\
\text { dengan menggunakan media } \\
\text { gambar. } \\
\text { 4. Membagikan uraian materi pada } \\
\text { setiap siswa. } \\
\text { 5. Guru menjelaskan fungsi dari materi } \\
\text { yang di bagiakan. } \\
\text { 6. Memberikan waktu } 10 \text { menit kepada } \\
\text { siswa untuk memahami materi yang } \\
\text { dibagikan guru. } \\
\text { 7. Membagikan sepotong kertas dan } \\
\text { memberikan kesempatan kepada } \\
\text { siswa untuk menulis pertanyaan dari } \\
\text { materi yang dibagikan. } \\
\text { 8. Mengumpulkan semua pertanyaan } \\
\text { siswa dan mengocoknya. } \\
\text { 9. Membagikan kembali pertanyaan } \\
\text { yang ditulis siswa secara acak. } \\
\text { 10. Memberikan kesempatan kepada } \\
\text { siswa untuk menjawab pertanyaan } \\
\text { yang didapatnya. }\end{array}$ & 85 Menit \\
\hline
\end{tabular}




\begin{tabular}{|l|l|l|l|}
\hline 3. & Kegiatan & 1. Guru melakukan refleksi. & 10 Menit \\
& Penutup & 2. Guru menutup pembelajaran dengan & \\
menujuk salah satu siswa untuk & \\
& & \\
& & & \\
\hline
\end{tabular}

I. Penilaian

Prosedur penilaian : penilaian hasil belajar dengan menggunakan alat evaluasi/soal terlampir.

Alat Penilaian : soal evaluasi.

\section{Wali Kelas O4A}

Sitti Marwiah. S.Pd.I

NIP : 196012311989102002
Makassar, 02 September 2020

Peneliti

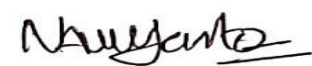

Navyseals Armadavanto

NIM : 16093188206007

Mengetahui

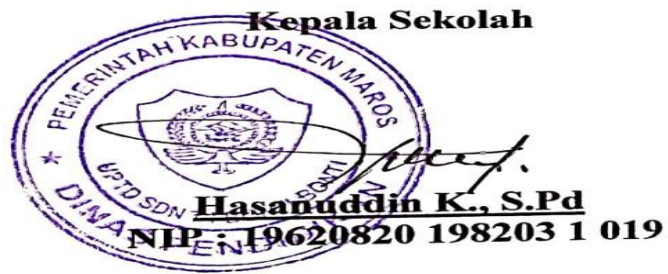




\section{RENCANA PELAKSANAAN PEMBELAJARAN (RPP)}

\section{SIKLUS I PERTEMUAN II}

Sekolah : SD NEGERI 74 BONTI - BONTI

Mata pelajaran : Bahasa Indonesia

Kelas/semester : III / I

Waktu : $3 \times 35$ menit

\section{A. Kompetensi Inti}

KI 1 : Menerima, menjalankan dan menghargai ajaran agama yang dianutnya.

KI 2 : Memiliki perilaku jujur, disiplin, tanggung jawab, santun, peduli, dan percaya diri dalam berinteraksi dengan keluarga, teman, guru, dan tetangganya.

KI 3 : Memahami pengetahuan faktual dengan cara mengamati (mendengar, melihat, membaca dan menanya) dan menanya berdasarkan rasa ingin tahu tentang dirinya, makhluk ciptaan Tuhan dan kegiatannya, dan benda-benda yang dijumpainya di rumah, sekolah, dan tempat bermain.

KI 4 : Menyajikan pengetahuan faktual dalam bahasa yang jelas, sistematis, dan logis, dalam karya yang estetis, dalam gerakan yang mencerminkan anak sehat, dan dalam tindakan yang mencerminkan peri-laku anak beriman dan berakhlak mulia.

\section{B. Kompetensi Dasar}

3.8 Menguraikan pesan dalam dongeng yang disajikan secara lisan, tulis, dan visual dengan tujuan untuk kesenangan.

4.8 Memeragakan pesan dalam dongeng sebagai bentuk ungkapan diri menggunakan kosa kata baku dan kalimat efektif

\section{Indikator}

3.8.1 Membaca dongeng dengan lafal, intonasi, dan ekspresi.

4.8.1 Mengidentifikasi informasi isi dongeng yang didengar. 


\section{Tujuan Pembelajaran}

Setelah Mendengarkan penjelasan guru, siswa dapat :

1. Dengan memperhatikan tanda baca, siswa dapat membaca dongeng dengan lafal, intonasi, dan ekspresi yang tepat.

2. Dengan menjawab pertanyaan, siswa dapat mengidentifikasi informasi isi dongeng yang didengar dengan tepat.

E. Materi Pokok

Dongeng "Pengembara dan Sebuah Pohon"

F. Karakter siswa yang diharapkan :

1. Disiplin

2. Tanggung jawab

3. Ketelitian .

G. Pendekatan, Strategi, Media dan Metode Pembelajaran

Pendekatan : Saintific

Strategi : Everyone Is A Teachere Here

Metode $\quad$ : Ceramah dan Diskusi 
H. Langkah-langkah Pembelajaran

\begin{tabular}{|c|c|c|c|}
\hline No & Kegiatan & Deskripsi & $\begin{array}{l}\text { Alokasi } \\
\text { Waktu }\end{array}$ \\
\hline 1. & $\begin{array}{c}\text { Kegiatan } \\
\text { Pendahuluan }\end{array}$ & $\begin{array}{l}\text { 1. Guru masuk kelas dengan } \\
\text { mengucapkan salam kepada siswa } \\
\text { dan menayakan kabar siswa. } \\
\text { 2. Guru meminta salah satu siswa } \\
\text { untuk memimpin doa. } \\
\text { 3. Guru mengkondisikan kelas dan } \\
\text { memeriksa kehadiran siswa. }\end{array}$ & 10 Menit \\
\hline 2. & Kegiatan Inti & $\begin{array}{l}\text { 1. Guru menyampaikan tujuan } \\
\text { pembelajaran dan memotifasi siswa. } \\
\text { 2. Guru menunjukan media gambar } \\
\text { kepada siswa. } \\
\text { 3. Guru menjelaskan materi dongeng } \\
\text { tentang Pengembara dan Sebuah } \\
\text { Pohon dengan menggunakan media } \\
\text { gambar. } \\
\text { 4. Membagikan uraian materi pada } \\
\text { setiap siswa. } \\
\text { 5. Guru menjelaskan fungsi dari materi } \\
\text { yang di bagiakan. } \\
\text { 6emberikan waktu } 10 \text { menit kepada } \\
\text { siswa untuk memahami materi yang } \\
\text { dibagikan guru. } \\
\text { 7. Membagikan sepotong kertas dan } \\
\text { memberikan kesempatan kepada } \\
\text { siswa untuk menulis pertanyaan dari } \\
\text { materi yang dibagikan. } \\
\text { 8. Mengumpulkan semua pertanyaan } \\
\text { siswa dan mengocoknya. } \\
\text { Membagikan kembali pertanyaan } \\
\text { yang ditulis siswa secara acak. } \\
\text { 10. Memberikan kesempatan kepada } \\
\text { siswa untuk menjawab pertanyaan } \\
\text { yang didapatnya. }\end{array}$ & 85 Menit \\
\hline
\end{tabular}




\begin{tabular}{|l|l|l|l|}
\hline 3. & Kegiatan & 1. Guru melakukan refleksi. & 10 Menit \\
& Penutup & Guru menutup pembelajaran dengan & \\
menujuk salah satu siswa untuk & \\
& & \\
\end{tabular}

I. Penilaian

Prosedur penilaian : penilaian hasil belajar dengan menggunakan alat evaluasi/soal terlampir.

Alat Penilaian : soal evaluasi.

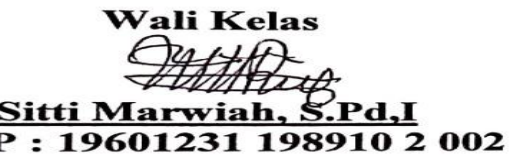

Makassar, 03 September 2020

Peneliti

Namezarte

Navyseals Armadayanto

NIM : 16093188206007

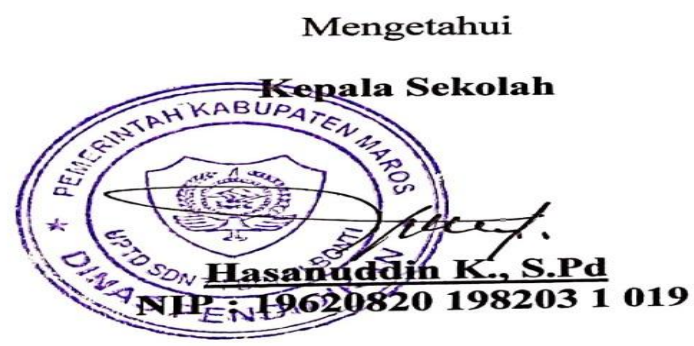




\section{RENCANA PELAKSANAAN PEMBELAJARAN (RPP)}

\section{SIKLUS II PERTEMUAN I}

Sekolah : SD NEGERI 74 BONTI - BONTI

Mata pelajaran : Bahasa Indonesia

Kelas/semester : III / I

Waktu : $3 \times 35$ menit

\section{A. Kompetensi Inti}

KI 1 : Menerima, menjalankan dan menghargai ajaran agama yang dianutnya.

KI 2 : Memiliki perilaku jujur, disiplin, tanggung jawab, santun, peduli, dan percaya diri dalam berinteraksi dengan keluarga, teman, guru, dan tetangganya.

KI 3 : Memahami pengetahuan faktual dengan cara mengamati (mendengar, melihat, membaca dan menanya) dan menanya berdasarkan rasa ingin tahu tentang dirinya, makhluk ciptaan Tuhan dan kegiatannya, dan benda-benda yang dijumpainya di rumah, sekolah, dan tempat bermain.

KI 4 : Menyajikan pengetahuan faktual dalam bahasa yang jelas, sistematis, dan logis, dalam karya yang estetis, dalam gerakan yang mencerminkan anak sehat, dan dalam tindakan yang mencerminkan peri-laku anak beriman dan berakhlak mulia.

\section{B. Kompetensi Dasar}

3.8 Menguraikan pesan dalam dongeng yang disajikan secara lisan, tulis, dan visual dengan tujuan untuk kesenangan.

4.8 Memeragakan pesan dalam dongeng sebagai bentuk ungkapan diri menggunakan kosa kata baku dan kalimat efektif

\section{Indikator}

3.8.1 Membaca dongeng dengan lafal, intonasi, dan ekspresi.

4.8.1 Mengidentifikasi informasi isi dongeng yang didengar. 


\section{Tujuan Pembelajaran}

Setelah Mendengarkan penjelasan guru, siswa dapat :

1. Dengan memperhatikan tanda baca, siswa dapat membaca dongeng dengan lafal, intonasi, dan ekspresi yang tepat.

2. Dengan menjawab pertanyaan, siswa dapat mengidentifikasi informasi isi dongeng yang didengar dengan tepat.

E. Materi Pokok

Dongeng "Asal Mula Buah Kelapa”

F. Karakter siswa yang diharapkan :

1. Disiplin

2. Tanggung jawab

3. Ketelitian .

\section{G. Pendekatan, Strategi, Media dan Metode Pembelajaran}

Pendekatan : Saintific

Strategi : Everyone Is A Teachere Here

Metode $\quad$ : Ceramah dan Diskusi 
H. Langkah-langkah Pembelajaran

\begin{tabular}{|c|c|c|c|}
\hline No & Kegiatan & Deskripsi & $\begin{array}{l}\text { Alokasi } \\
\text { Waktu }\end{array}$ \\
\hline 1. & $\begin{array}{c}\text { Kegiatan } \\
\text { Pendahuluan }\end{array}$ & $\begin{array}{l}\text { 1. Guru masuk kelas dengan } \\
\text { mengucapkan salam kepada siswa } \\
\text { dan menayakan kabar siswa. } \\
\text { 2. Guru meminta salah satu siswa } \\
\text { untuk memimpin doa. } \\
\text { 3. Guru mengkondisikan kelas dan } \\
\text { memeriksa kehadiran siswa. }\end{array}$ & 10 Menit \\
\hline 2. & Kegiatan Inti & $\begin{array}{l}\text { 1. Guru menyampaikan tujuan } \\
\text { pembelajaran dan memotifasi siswa. } \\
\text { 2. Guru menunjukan media gambar } \\
\text { kepada siswa. } \\
\text { 3. Guru menjelaskan materi dongeng } \\
\text { tentang Asal Mula Buah Kelapa } \\
\text { dengan menggunakan media } \\
\text { gambar. } \\
\text { 4. Membagikan uraian materi pada } \\
\text { setiap siswa. } \\
\text { 5. Guru menjelaskan fungsi dari materi } \\
\text { yang di bagiakan. } \\
\text { Memberikan waktu } 10 \text { menit kepada } \\
\text { siswa untuk memahami materi yang } \\
\text { dibagikan guru. } \\
\text { Membagikan sepotong kertas dan } \\
\text { memberikan kesempatan kepada } \\
\text { siswa untuk menulis pertanyaan dari } \\
\text { materi yang dibagikan. } \\
\text { 8. Mengumpulkan semua pertanyaan } \\
\text { siswa dan mengocoknya. } \\
\text { 9embagikan kembali pertanyaan } \\
\text { yang ditulis siswa secara acak. } \\
\text { 10. Memberikan kesempatan kepada } \\
\text { siswa untuk menjawab pertanyaan } \\
\text { yang didapatnya. }\end{array}$ & 85 Menit \\
\hline
\end{tabular}




\begin{tabular}{|l|l|l|l|}
\hline 3. & Kegiatan & 1. Guru melakukan refleksi. & 10 Menit \\
& Penutup & Guru menutup pembelajaran dengan & \\
menujuk salah satu siswa untuk & \\
& & \\
\end{tabular}

I. Penilaian

Prosedur penilaian : penilaian hasil belajar dengan menggunakan alat evaluasi/soal terlampir.

Alat Penilaian : soal evaluasi.

\section{Wali Kelas DetA}

Sitti Marwiah. S.Pd.I

NIP : 196012311989102002
Makassar, 07 September 2020

Peneliti

Nauefarte
Navyseals Armadayanto

NIM : 16093188206007

Mengetahui

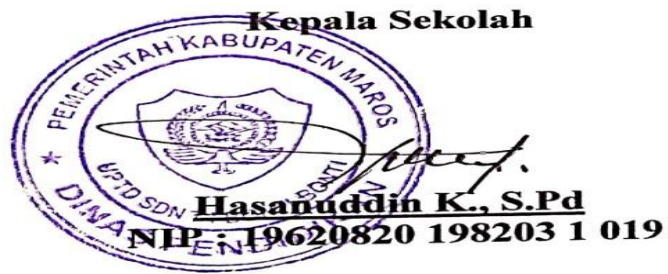




\section{RENCANA PELAKSANAAN PEMBELAJARAN (RPP)}

\section{SIKLUS II PERTEMUAN I}

Sekolah : SD NEGERI 74 BONTI - BONTI

Mata pelajaran : Bahasa Indonesia

Kelas/semester : : III / I

Waktu : $3 \times 35$ menit

\section{Kompetensi Inti}

KI 1 : Menerima, menjalankan dan menghargai ajaran agama yang dianutnya.

KI 2 : Memiliki perilaku jujur, disiplin, tanggung jawab, santun, peduli, dan percaya diri dalam berinteraksi dengan keluarga, teman, guru, dan tetangganya.

KI 3 : Memahami pengetahuan faktual dengan cara mengamati (mendengar, melihat, membaca dan menanya) dan menanya berdasarkan rasa ingin tahu tentang dirinya, makhluk ciptaan Tuhan dan kegiatannya, dan benda-benda yang dijumpainya di rumah, sekolah, dan tempat bermain.

KI 4 : Menyajikan pengetahuan faktual dalam bahasa yang jelas, sistematis, dan logis, dalam karya yang estetis, dalam gerakan yang mencerminkan anak sehat, dan dalam tindakan yang mencerminkan peri-laku anak beriman dan berakhlak mulia.

\section{Kompetensi Dasar}

3.8 Menguraikan pesan dalam dongeng yang disajikan secara lisan, tulis, dan visual dengan tujuan untuk kesenangan.

4.8 Memeragakan pesan dalam dongeng sebagai bentuk ungkapan diri menggunakan kosa kata baku dan kalimat efektif

\section{Indikator}

3.8.1 Membaca dongeng dengan lafal, intonasi, dan ekspresi.

4.8.1 Mengidentifikasi informasi isi dongeng yang didengar. 


\section{Tujuan Pembelajaran}

Setelah Mendengarkan penjelasan guru, siswa dapat :

1. Dengan memperhatikan tanda baca, siswa dapat membaca dongeng dengan lafal, intonasi, dan ekspresi yang tepat.

2. Dengan menjawab pertanyaan, siswa dapat mengidentifikasi informasi isi dongeng yang didengar dengan tepat.

E. Materi Pokok

Dongeng "Kisah Semut dan Merpati"

F. Karakter siswa yang diharapkan :

1. Disiplin

2. Tanggung jawab

3. Ketelitian .

\section{G. Pendekatan, Strategi, Media dan Metode Pembelajaran}

Pendekatan : Saintific

Strategi : Everyone Is A Teachere Here

Metode $\quad$ : Ceramah dan Diskusi 
H. Langkah-langkah Pembelajaran

\begin{tabular}{|c|c|c|c|}
\hline No & Kegiatan & Deskripsi & $\begin{array}{l}\text { Alokasi } \\
\text { Waktu }\end{array}$ \\
\hline 1. & $\begin{array}{c}\text { Kegiatan } \\
\text { Pendahuluan }\end{array}$ & 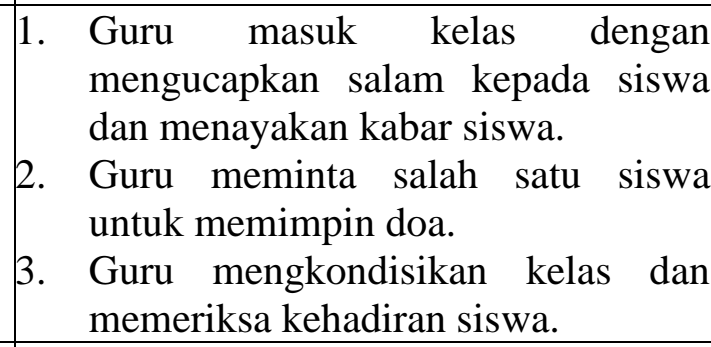 & 10 Menit \\
\hline 2. & Kegiatan Inti & $\begin{array}{l}\text { 1. Guru menyampaikan tujuan } \\
\text { pembelajaran dan memotifasi siswa. } \\
\text { 2. Guru menunjukan media gambar } \\
\text { kepada siswa. } \\
\text { 3. Guru menjelaskan materi dongeng } \\
\text { tentang Kisah Semut dan Merpati } \\
\text { dengan menggunakan media } \\
\text { gambar. } \\
\text { 4. Membagikan uraian materi pada } \\
\text { setiap siswa. } \\
\text { 5. Guru menjelaskan fungsi dari materi } \\
\text { yang di bagiakan. } \\
\text { 6. Memberikan waktu } 10 \text { menit kepada } \\
\text { siswa untuk memahami materi yang } \\
\text { dibagikan guru. } \\
\text { 7. Membagikan sepotong kertas dan } \\
\text { memberikan kesempatan kepada } \\
\text { siswa untuk menulis pertanyaan dari } \\
\text { materi yang dibagikan. } \\
\text { 8. Mengumpulkan semua pertanyaan } \\
\text { siswa dan mengocoknya. } \\
\text { 9. Membagikan kembali pertanyaan } \\
\text { yang ditulis siswa secara acak. } \\
\text { 10. Memberikan kesempatan kepada } \\
\text { siswa untuk menjawab pertanyaan } \\
\text { yang didapatnya. }\end{array}$ & 85 Menit \\
\hline
\end{tabular}




\begin{tabular}{|l|l|l|l|}
\hline 3. & Kegiatan & 1. Guru melakukan refleksi. & 10 Menit \\
& Penutup & Guru menutup pembelajaran dengan & \\
menujuk salah satu siswa untuk & & \\
& & & \\
\hline
\end{tabular}

I. Penilaian

Prosedur penilaian : penilaian hasil belajar dengan menggunakan alat evaluasi/soal terlampir.

Alat Penilaian : soal evaluasi.

Wali Kelas

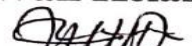

HAfor

Sitti Marwiah, S.Pd,I

NIP : 196012311989102002
Makassar, 08 September 2020

Peneliti

Namefarte

Navyseals Armadayanto NIM : 16093188206007

Mengetahui

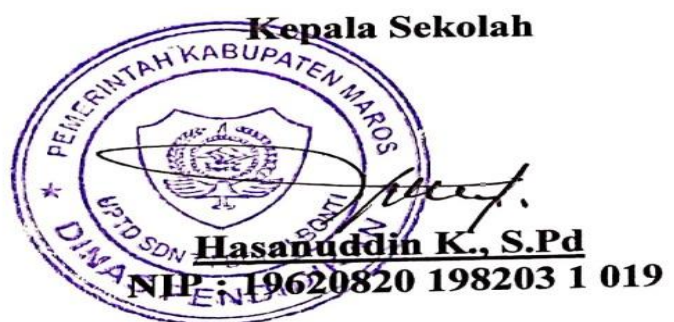




\section{LAMPIRAN II}

MATERI 


\section{"Pohon Apel Yang tulus"}

Dahulu kala, ada sebuah pohon apel besar. Ada seorang anak laki-laki bermain di sekitar pohon itu. Dia sangat menyayangi pohon itu. Pohon itu juga senang bermain bersamanya.

Waktu berlalu, anak laki-laki itu tumbuh dewasa. Suatu hari, ia datang kembali. Pohon apel menyambutnya dengan gembira. "Ayo, bermainlah bersamaku," ajak si Pohon Apel.

“Ah, aku tak punya waktu untuk bermain. Kami membutuhkan rumah untuk tempat tinggal. Bisakah kau membantuku?"

"Kamu boleh memotong cabang-cabang pohonku ini untuk membangun rumahmu." Jadi anak laki-

laki itu memotong semua cabang pohon dan pergi dengan riang. Pohon apel itu senang melihat temannya bahagia. Tapi dia tak pernah kembali sejak saat itu.

Pohon apel kembali merasa kesepian

dan sedih.

Akhirnya, laki-laki itu kembali lagi. Laki-laki itu dan pohon apel sekarang sudah sama-sama tua. "Aku sudah tak bisa memberikan apa-apa," kata Pohon Apel. "Tidak apa-apa. Aku hanya membutuhkan se-buah tempat untuk beristirahat," jawab laki-laki itu.

"Baik! Sisa batang pohon tua adalah tempat terbaik untuk bersandar dan beristirahat. Duduklah

sini bersamaku dan istirahatlah," kata pohon apel. Laki-laki itu pun duduk bersandarkan pada

batang pohon yang masih tersisa. Pohon apel pun menangis bahagia. Akhirnya mereka pun bersama

lagi. 


\section{"Pengembara dan Sebuah Pohon"}

Dua orang pengembara berjalan di sepanjang jalan yang berdebu dan tandus di hari yang sangat panas. Tidak lama kemudian, mereka menemukan sebuah pohon besar. Dengan gembira, keduanya lalu berteduh dari teriknya sinar matahari di bawah naungan daun-daun pohon besar yang lebat. Saat beristirahat, mereka melihat ke atas pohon. Salah seorang pengembara berkata kepada teman seperjalanannya, "Betapa tidak bergunanya pohon besar ini! Pohon ini tidak memiliki buah sehingga tidak berguna untuk manusia sama sekali."

Pohon besar tersebut lalu berkata, "Kamu manusia yang tidak tahu berterima kasih!“ Pohon itu berkata lagi, "Kamu datang dan bernaung di bawah daundaunku. Kamu menikmati teduhnya perlindungan cabang dan daunku. Kamu masih menyebutku tidak berguna sama sekali?” 


\section{"Asal Mula Buah Kelapa"}

Seorang laki-laki mendaki gunung yang tinggi. Ia ingin mengunjungi penyihir sakti. Penyihir sakti mempersilakan laki-laki itu masuk ke pondoknya. "Wahai Penyihir sakti, ada sesuatu yang ingin kumohon darimu," kata laki-laki itu sambil menunduk dengan hormat. "Aku ingin diberi sesuatu olehmu, agar aku menjadi seseorang yang sangat berguna bagi setiap orang." "Permintaanmu cukup bagus," sahut Penyihir sakti. Ia mengeluarkan sebuah kotak hijau yang kecil. Dia berkata, “Kau baru boleh membukanya jika kau sudah tiba di rumah!” Laki-laki itu menerima kotak hijau tersebut dengan perasaan gembira. Setelah mengucapkan terima kasih, dia berjalan menuruni gunung. Di tengah perjalanan dia tergoda untuk membuka kotak hijau itu. Ia ingin melihat apa isinya, namun ia tidak jadi membukanya. Saat ia ingat pada pesan Penyihir sakti. Ketika tiba di kaki gunung, lagi-lagi dia tergoda, ingin melihat isi kotak hijau tersebut. Ia lalu membuka kotak hijau itu. Tiba-tiba laki-laki itu berubah menjadi pohon yang daunnya panjang dan buahnya besar-besar. Terdengar suara Penyihir sakti dari puncak gunung. "Karena kau tak mematuhi kata-kataku, kau berubah menjadi pohon kelapa. Namun, permohonanmu tetap terkabul. Kau sangat berguna. Tiap bagian darimu berguna bagi manusia. Daunmu, buahmu, dan batangmu dapat dimanfaatkan manusia. Sejak saat itu, pohon kelapa cepat berkembang biak, sehingga bisa dijumpai di mana-mana. Orang menghargai pohon kelapa karena banyak gunanya 


\section{"Kisah Semut dan Merpati"}

Pada suatu hari, ada seekor semut yang sedang berjalan-jalan mencari makan di pinggir sungai. Seperti biasa, dia berjalan dengan riang dan karena kurang hatihati tiba-tiba ia terjatuh ke dalam sungai. Arus sungai menghanyutkannya. Semut itu timbul tenggelam dan kelelahan. Ia berusaha untuk menepi, tetapi tidak berhasil. Seekor burung merpati kebetulan bertengger di ranting pohon yang melintang di atas sungai, melihat semut yang hampir tenggelam dan merasa iba. Burung merpati ini memetik daun dan menjatuhkannya di dekat semut. Semut merayap naik ke atas daun. Akhirnya, ia berhasil menyelamatkan dirinya dengan bantuan daun tersebut dan mendarat di tepi sungai. Tidak lama kemudian, sang semut melihat seorang pemburu burung sedang mengendap-endap berusaha mendekati burung merpati yang telah menolongnya tadi. Semut menyadari bahaya yang membayangi merpati yang baik tersebut. Ia segera berlari mendekati pemburu dan menggigit kaki sang pemburu. Pemburu itu kesakitan dan terkejut. Ia mengibaskan ranting yang tadinya akan digunakan untuk menangkap burung. Burung Merpati menyadari keberadaan pemburu yang sibuk mengibas-ngibaskan ranting. Akhirnya sang burung pun terbang menyelamatkan dirinya. 


\section{Soal Dan Jawaban}

\section{A. Kerjakan soal di bawah ini dengan baik dan benar!}

1. Pelaku dalam cerita atau dongeng disebut .....? Jawaban : Tokoh.

2. Bagian karangan yang mengandung satu ide pokok disebut ....? Jawaban: paragraf pokok

3. Siapa teman pohon apel? Jawaban: Seorang anak laki-laki.

4. Apa yang dirasakan pohon apel saat bermain bersama temannya? Jawaban: Pohon apel merasa senang

5. Apa kebaikan yang diberikan pohon apel?

Jawaban: Pohon apel memberikan cabang-cabang pohonnya untuk dijadikan bahan pembuat rumah atau pohon apel menyediakan akar pohonnya yang tersisa sebagai tempat beristirahat.

6. Mengapa pohon apel merasa kesepian dan sedih?

Jawaban: Pohon apel merasa kesepian dan sedih karena tidak bertemu dan bermain bersama temannya

7. Di akhir cerita, mengapa pohon apel menangis?

Jawaban: Pohon apel menangis karena merasa bahagia bisa bersama-sama dengan temannya lagi.

8. Berikanlah 3 contoh dongeng yang kamu ketahui?

Jawaban: Si kancil dan buaya, Kura-kura dan kelinci, Bawang merah dan bawang putih

9. Cerita Pohon Apel yang Tulus mengajarkan kita untuk setia kepada?

Jawaban: Sahabat

10. Sebutkan 1 dongeng yang berasal dari daerahmu!

Jawaban: Legenda Rawa Pening

Ketrangan: Benar (1) Salah (0)

$$
\begin{aligned}
\text { Nilai } & =\frac{\text { Skor yang diperoleh }}{\text { Skor Total }} \times 100 \\
& =\frac{10}{10} \times 100 \\
& =100
\end{aligned}
$$




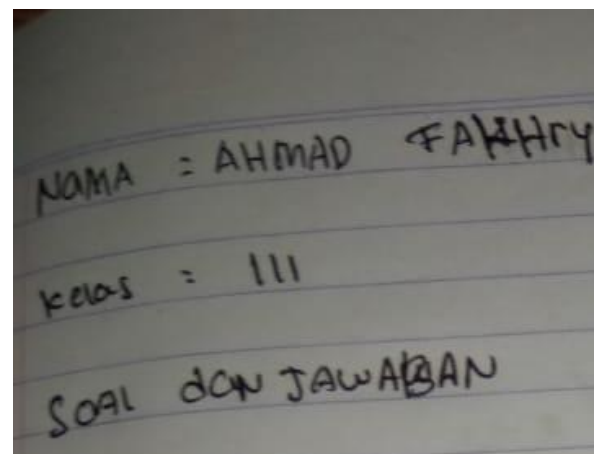
A. KerJakan SOAL dibawah pri dengan baik
dan Benar!

pelaku dacam ceritar, atau dongeng disebut?
tawaban: Toko

Bagian Karangan yang mengandurd SaOu ide Pokok disebut? Jenuseil juwaban: paragraf polcok. siapa teman pohon aptl? jewabans seorang anak laki-laki

apa vang di rasakan pohon applel Temalnny jawabur.Pohon appel merasa senarty

apa kebaikan yang diberi foron copper jawabans pohon apt memberi cabong-cabang 
78

pohanta Unulk di Jadikan Pembucet Romah atac pohon apel menYediakon akor pohang ys tersisa sebagat lempat beristrahatid

6. mengapa pohon apel merasa sepiden sedi?

Jawaban: Ponon apel mercasa sedi dan sepi karena tidak Beternu temam

7 diakhir ceritu mengapa Ponon apel menangis?

Juwaban. Pohon appet menangin Karena merara Babagia Bisa Bersama sama temannya lagi

8 Bern Berikan 3 contoh dongen yang kamo ketahuwi?

Jawaban: sikankic dan Buaya kura kura dan kelina, Bawang $p$ tin dan Bawang merah.

cerita pohon appec yang tulus mengas kan kita untok setia kepada? JawaBun: SahaBaf

78 
79 - sebut safu dongeng Yang Berasac

jawaBan. Keng legenda rawa Bening

$$
\begin{aligned}
& =\frac{10}{10} \times 100 \\
& =100
\end{aligned}
$$

79 


\section{LAMPIRAN III}

\section{LEMBAR OBSERVASI GURU DAN SISWA SIKLUS I DAN SIKLUS II}


Lampiran 3. Lembar Observasi Aktivitas Mengajar Guru Siklus I

$$
\begin{array}{ll}
\text { Nama Sekolah } & \text { : SD Negeri 74 Bonti - Bonti. } \\
\text { Kelas/ Semester } & : 3 / 1 \\
\text { Mata Pelajaran } & \text { : Bahasa Indonesia }
\end{array}
$$

\begin{tabular}{|c|c|c|c|c|c|c|c|c|c|c|c|}
\hline \multirow{3}{*}{$\begin{array}{l}\mathrm{N} \\
\mathrm{o}\end{array}$} & \multirow{3}{*}{ Indikator } & \multicolumn{10}{|c|}{$\begin{array}{l}\text { Skala Penilaian } \\
\end{array}$} \\
\hline & & \multicolumn{5}{|c|}{ Pertemuan I } & \multicolumn{5}{|c|}{ Pertemuan II } \\
\hline & & 1 & 2 & 3 & 4 & 5 & 1 & 2 & 3 & 4 & 5 \\
\hline 1. & $\begin{array}{l}\text { Keterampilan membuka } \\
\text { pelajaran }\end{array}$ & & & & & $\checkmark$ & & & & & $\checkmark$ \\
\hline 2. & $\begin{array}{l}\text { Keterampilan menjelaskan } \\
\text { pelajaran }\end{array}$ & & & & $\checkmark$ & & & & & & $\checkmark$ \\
\hline 3. & Keterampilan mengelola kelas & & & $\checkmark$ & & & & & $\checkmark$ & & \\
\hline 4. & $\begin{array}{l}\text { Melaksanakan pembelajaran } \\
\text { sesuai dengan RPP yang telah } \\
\text { disusun }\end{array}$ & & & $\checkmark$ & & & & & $\sqrt{ }$ & & \\
\hline 5. & $\begin{array}{l}\text { Keterampilan memberi } \\
\text { motivasi }\end{array}$ & & $\checkmark$ & & & & & & & $\checkmark$ & \\
\hline 6. & $\begin{array}{l}\text { Keterampilan berinteraksi } \\
\text { dengan siswa }\end{array}$ & & & $\checkmark$ & & & & & & & $\checkmark$ \\
\hline 7. & $\begin{array}{l}\text { Keterampilan } \\
\text { membimbing/mengarahkan } \\
\text { siswa }\end{array}$ & & $\checkmark$ & & & & & $\checkmark$ & & & \\
\hline 8. & $\begin{array}{l}\text { Keterampilan menetapkan } \\
\text { metode pembelajaran dengan } \\
\text { efektif }\end{array}$ & & $\checkmark$ & & & & & & $\checkmark$ & & \\
\hline 9. & $\begin{array}{l}\text { Keterampilan menggunakan } \\
\text { media dan sumber pelajaran }\end{array}$ & & & $\checkmark$ & & & & & $\sqrt{\checkmark}$ & & \\
\hline 10 & $\begin{array}{l}\text { Keterampilan menutup } \\
\text { pelajaran }\end{array}$ & & & $\checkmark$ & & & & & & & $\checkmark$ \\
\hline & Jumlah Skor Tiap Butir & & 6 & 15 & 4 & 5 & & 2 & 12 & 4 & 20 \\
\hline & Total skor & & & 38 & & & & & 38 & & \\
\hline
\end{tabular}

Keterangan:
Sangat baik
Baik
Cukup
Kurang
Sangat Kurang (1)
Observer
Sitti Marwiah, S.Pd,I
NIP : 196012311989102002

Makassar, 03 September 2020 
Lampiran 4. Lembar Observasi Aktivitas Mengajar Guru Siklus II

$$
\begin{array}{ll}
\text { Nama Sekolah } & \text { : SD Negeri 74 Bonti - Bonti. } \\
\text { Kelas/ Semester } & : 3 / 1 \\
\text { Mata Pelajaran } & : \text { Bahasa Indonesia }
\end{array}
$$

\begin{tabular}{|c|c|c|c|c|c|c|c|c|c|c|c|}
\hline \multirow{3}{*}{$\begin{array}{l}\mathrm{N} \\
\mathrm{o}\end{array}$} & \multirow{3}{*}{ Indikator } & \multicolumn{10}{|c|}{ Skala Penilaian } \\
\hline & & \multicolumn{5}{|c|}{ Pertemuan I } & \multicolumn{5}{|c|}{ Pertemuan II } \\
\hline & & 1 & 2 & 3 & 4 & 5 & 1 & 2 & 3 & 4 & 5 \\
\hline 1. & $\begin{array}{l}\text { Keterampilan membuka } \\
\text { pelajaran }\end{array}$ & & & & & $\checkmark$ & & & & & $\checkmark$ \\
\hline 2. & $\begin{array}{l}\text { Keterampilan menjelaskan } \\
\text { pelajaran }\end{array}$ & & & & $\checkmark$ & & & & & & $\checkmark$ \\
\hline 3. & Keterampilan mengelola kelas & & & & $\checkmark$ & & & & & $\checkmark$ & \\
\hline 4. & $\begin{array}{l}\text { Melaksanakan pembelajaran } \\
\text { sesuai dengan RPP yang telah } \\
\text { disusun }\end{array}$ & & & $\checkmark$ & & & & $\sqrt{ }$ & & & \\
\hline 5. & Keterampilan memberi motivasi & & & & & $\checkmark$ & & & & $\checkmark$ & \\
\hline 6. & $\begin{array}{l}\text { Keterampilan berinteraksi } \\
\text { dengan siswa }\end{array}$ & & & & $\checkmark$ & & & & & & $\checkmark$ \\
\hline 7. & $\begin{array}{l}\text { Keterampilan } \\
\text { membimbing/mengarahkan } \\
\text { siswa }\end{array}$ & & & & & $\checkmark$ & & & & $\checkmark$ & \\
\hline 8. & $\begin{array}{l}\text { Keterampilan menetapkan } \\
\text { metode pembelajaran dengan } \\
\text { efektif }\end{array}$ & & & & $\checkmark$ & & & & $\checkmark$ & & \\
\hline 9. & $\begin{array}{l}\text { Keterampilan menggunakan } \\
\text { media dan sumber pelajaran }\end{array}$ & & & $\checkmark$ & & & & & $\checkmark$ & & \\
\hline 10 & $\begin{array}{l}\text { Keterampilan menutup } \\
\text { pelajaran }\end{array}$ & & & & $\checkmark$ & & & & & & $\checkmark$ \\
\hline & Jumlah Skor Tiap Butir & & & 6 & $\begin{array}{l}2 \\
0\end{array}$ & 15 & & 2 & 6 & 12 & 20 \\
\hline & Total skor & & & 4 & & & & & 38 & & \\
\hline
\end{tabular}

Keterangan:

Sangat baik

Baik

Cukup

Kurang

Sangat Kurang (1)
Makassar, 08 September 2020
Observer

Sitti Marwiah, S.Pd,I NIP : 196012311989102002 
Lampiran 4. Aktivitas Siswa

OBSERVASI AKTIVITAS SISWA

Untuk mendapatkan informasi lengkap

Tentang minat siswa selama belajar Bahasa Indonesia

\begin{tabular}{|c|l|c|c|c|c|c|}
\hline & & \multicolumn{5}{|c|}{ PENILAIAN } \\
NO & \multirow{2}{*}{ ASPEK YANG DINILAI } & \multicolumn{5}{|c|}{} \\
\cline { 3 - 6 } & & $\mathbf{1}$ & $\mathbf{2}$ & $\mathbf{3}$ & $\mathbf{4}$ & $\mathbf{5}$ \\
\hline $\mathbf{1}$ & $\begin{array}{l}\text { Mendengarkan } \\
\text { Imemperhatikan penjelasan } \\
\text { guru }\end{array}$ & & & & & \\
\hline $\mathbf{2}$ & $\begin{array}{l}\text { Giat melakukan tugas-tugas } \\
\text { kelompok }\end{array}$ & & & & & \\
\hline $\mathbf{3}$ & $\begin{array}{l}\text { Mengajukan pertanyaan / } \\
\text { menanggapi pertanyaan }\end{array}$ & & & & & \\
\hline $\mathbf{4}$ & $\begin{array}{l}\text { Dapat bekerja sama dalam } \\
\text { Kelompok }\end{array}$ & & & & & \\
\hline $\mathbf{5}$ & Giat membaca buku & & & & & \\
\hline $\mathbf{6}$ & $\begin{array}{l}\text { Dapat berdiskusi tentang } \\
\text { materi yang diajarkan }\end{array}$ & & & & & \\
\hline & Jumlah & & & & & \\
\hline
\end{tabular}

Keterangan Skala Penilaian

1 : Tidak melakukan

2: Dilakukan kurang baik

3 : Dilakukan cukup baik

4: Dilakukan dengan baik

5: Dilakukan sangat baik 
Tabel Aktivitas siswa Siklus I

\begin{tabular}{|c|c|c|c|c|c|c|c|c|}
\hline \multirow{2}{*}{ NAMA } & \multicolumn{6}{|c|}{ INDIKATOR } & \multirow{2}{*}{ NILAI } & \multirow{2}{*}{ KATEGORI } \\
\hline & 1 & 2 & 3 & 4 & 5 & 6 & & \\
\hline $\begin{array}{l}\text { Ahmad } \\
\text { Fakhry }\end{array}$ & 3 & 4 & 3 & 3 & 3 & 5 & 70 & Baik \\
\hline $\begin{array}{c}\text { Arman } \\
\text { Maulana }\end{array}$ & 4 & 3 & 5 & 2 & 4 & 4 & 73 & Baik \\
\hline $\begin{array}{c}\text { Ayuni } \\
\text { Salsabila }\end{array}$ & 5 & 4 & 5 & 4 & 5 & 5 & 93 & $\begin{array}{l}\text { Sangat } \\
\text { Baik }\end{array}$ \\
\hline $\begin{array}{l}\text { Bashfar } \\
\text { Soleh }\end{array}$ & 2 & 1 & 3 & 3 & 1 & 2 & 40 & Kurang \\
\hline $\begin{array}{c}\text { Fitria } \\
\text { Fadilah Al- } \\
\text { Madinah }\end{array}$ & 2 & 4 & 4 & 3 & 4 & 4 & 70 & Baik \\
\hline $\begin{array}{c}\text { Futri Alya } \\
\text { Dewi }\end{array}$ & 1 & 2 & 2 & 2 & 2 & 2 & 37 & Kurang \\
\hline Keysyafira & 3 & 5 & 4 & 4 & 3 & 3 & 73 & Baik \\
\hline Lutfiah & 1 & 3 & 2 & 1 & 2 & 3 & 40 & Kurang \\
\hline M. Fadil & 4 & 3 & 3 & 2 & 4 & 1 & 57 & Cukup \\
\hline $\begin{array}{l}\text { M.zidni } \\
\text { Khatami }\end{array}$ & 5 & 5 & 4 & 5 & 4 & 4 & 90 & $\begin{array}{l}\text { Sangat } \\
\text { Baik }\end{array}$ \\
\hline $\begin{array}{l}\text { Muh. Al } \\
\text { Fatir }\end{array}$ & 2 & 3 & 2 & 3 & 3 & 3 & 53 & Cukup \\
\hline $\begin{array}{l}\text { Muh. Fahril } \\
\text { Ramadhan }\end{array}$ & 1 & 1 & 1 & 1 & 1 & 1 & 20 & $\begin{array}{l}\text { Kurang } \\
\text { Sekali }\end{array}$ \\
\hline $\begin{array}{c}\text { Muh. } \\
\text { Fahrizal }\end{array}$ & 1 & 1 & 2 & 3 & 2 & 2 & 37 & Kurang \\
\hline $\begin{array}{l}\text { Muh. Hatta } \\
\text { Rahmat }\end{array}$ & 3 & 4 & 3 & 4 & 4 & 3 & 70 & Baik \\
\hline $\begin{array}{l}\text { Muh. Faiz } \\
\text { Al- Qoadri }\end{array}$ & 2 & 3 & 2 & 1 & 2 & 1 & 37 & Kurang \\
\hline $\begin{array}{c}\text { Muhammad } \\
\text { Fahdil Aksa } \\
\text { Ratu }\end{array}$ & 3 & 4 & 4 & 4 & 3 & 3 & 70 & Baik \\
\hline $\begin{array}{c}\text { Muhammad } \\
\text { Farhan } \\
\text { Saputra }\end{array}$ & 4 & 4 & 5 & 5 & 4 & 5 & 90 & $\begin{array}{l}\text { Sangat } \\
\text { Baik }\end{array}$ \\
\hline $\begin{array}{c}\text { Muhammad } \\
\text { Rizky }\end{array}$ & 2 & 3 & 2 & 1 & 2 & 2 & 40 & Kurang \\
\hline $\begin{array}{l}\text { Musfira } \\
\text { Achmad }\end{array}$ & 4 & 3 & 3 & 3 & 2 & 4 & 63 & Baik \\
\hline
\end{tabular}




\begin{tabular}{|c|c|c|c|c|c|c|c|l|}
\hline $\begin{array}{c}\text { Nur. Azizah } \\
\text { Al } \\
\text { Munawarah }\end{array}$ & 4 & 3 & 2 & 3 & 3 & 3 & 60 & Cukup \\
\hline $\begin{array}{c}\text { Nur Wafia } \\
\text { Utami }\end{array}$ & 2 & 1 & 2 & 3 & 1 & 1 & 33 & Kurang \\
\hline $\begin{array}{c}\text { Nurul Afika } \\
\text { Sari }\end{array}$ & 3 & 4 & 4 & 2 & 5 & 3 & 70 & Cukup \\
\hline $\begin{array}{c}\text { Putri } \\
\text { Meilani }\end{array}$ & 4 & 4 & 5 & 4 & 5 & 5 & 90 & $\begin{array}{l}\text { Sangat } \\
\text { Baik }\end{array}$ \\
\hline $\begin{array}{c}\text { Rahmat } \\
\text { Fauzan } \\
\text { Jamal }\end{array}$ & 5 & 4 & 4 & 5 & 5 & 5 & 93 & $\begin{array}{l}\text { Sangat } \\
\text { Baik }\end{array}$ \\
\hline $\begin{array}{c}\text { Ruslan } \\
\text { Sitti }\end{array}$ & 3 & 1 & 2 & 2 & 4 & 3 & 50 & Cukup \\
\hline $\begin{array}{c}\text { Fatimah } \\
\text { Assahra }\end{array}$ & 3 & 2 & 3 & 2 & 3 & 2 & 50 & Cukup \\
\hline Umar & 1 & 1 & 2 & 3 & 2 & 2 & 37 & Kurang \\
\hline
\end{tabular}


Tabel Aktivitas Siswa Siklus II

\begin{tabular}{|c|c|c|c|c|c|c|c|c|}
\hline \multirow{2}{*}{ NAMA } & \multicolumn{6}{|c|}{ INDIKATOR } & \multirow{2}{*}{ NILAI } & \multirow{2}{*}{ KATEGORI } \\
\hline & 1 & 2 & 3 & 4 & 5 & 6 & & \\
\hline $\begin{array}{l}\text { Ahmad } \\
\text { Fakhry }\end{array}$ & 4 & 4 & 5 & 3 & 4 & 5 & 83 & $\begin{array}{l}\text { Sangat } \\
\text { Baik }\end{array}$ \\
\hline $\begin{array}{c}\text { Arman } \\
\text { Maulana }\end{array}$ & 4 & 3 & 5 & 2 & 4 & 4 & 73 & Baik \\
\hline $\begin{array}{c}\text { Ayuni } \\
\text { Salsabila }\end{array}$ & 5 & 4 & 5 & 4 & 5 & 5 & 93 & $\begin{array}{l}\text { Sangat } \\
\text { Baik }\end{array}$ \\
\hline $\begin{array}{l}\text { Bashfar } \\
\text { Soleh }\end{array}$ & 2 & 1 & 3 & 3 & 3 & 2 & 47 & Cukup \\
\hline $\begin{array}{c}\text { Fitria } \\
\text { Fadilah Al- } \\
\text { Madinah }\end{array}$ & 2 & 4 & 4 & 3 & 4 & 4 & 70 & Baik \\
\hline $\begin{array}{c}\text { Futri Alya } \\
\text { Dewi }\end{array}$ & 4 & 3 & 4 & 5 & 4 & 5 & 83 & $\begin{array}{l}\text { Sangat } \\
\text { Baik } \\
\end{array}$ \\
\hline Keysyafira & 3 & 5 & 4 & 4 & 3 & 3 & 73 & Baik \\
\hline Lutfiah & 3 & 3 & 3 & 4 & 2 & 3 & 60 & Cukup \\
\hline M. Fadil & 4 & 3 & 3 & 3 & 4 & 4 & 70 & Baik \\
\hline $\begin{array}{r}\text { M.zidni } \\
\text { Khatami }\end{array}$ & 5 & 5 & 4 & 5 & 4 & 4 & 90 & $\begin{array}{l}\text { Sangat } \\
\text { Baik } \\
\end{array}$ \\
\hline $\begin{array}{l}\text { Muh. Al } \\
\text { Fatir }\end{array}$ & 5 & 5 & 4 & 4 & 4 & 5 & 90 & $\begin{array}{l}\text { Sangat } \\
\text { Baik } \\
\end{array}$ \\
\hline $\begin{array}{l}\text { Muh. Fahril } \\
\text { Ramadhan }\end{array}$ & 3 & 4 & 3 & 2 & 3 & 4 & 63 & Cukup \\
\hline $\begin{array}{c}\text { Muh. } \\
\text { Fahrizal }\end{array}$ & 1 & 1 & 2 & 3 & 2 & 4 & 43 & Cukup \\
\hline $\begin{array}{l}\text { Muh. Hatta } \\
\text { Rahmat }\end{array}$ & 3 & 4 & 3 & 4 & 4 & 3 & 70 & Baik \\
\hline $\begin{array}{l}\text { Muh. Faiz } \\
\text { Al- Qoadri }\end{array}$ & 5 & 4 & 3 & 5 & 4 & 5 & 87 & $\begin{array}{l}\text { Sangat } \\
\text { Baik }\end{array}$ \\
\hline $\begin{array}{c}\text { Muhammad } \\
\text { Fahdil Aksa } \\
\text { Ratu }\end{array}$ & 3 & 4 & 4 & 4 & 3 & 3 & 70 & Baik \\
\hline $\begin{array}{c}\text { Muhammad } \\
\text { Farhan } \\
\text { Saputra }\end{array}$ & 4 & 4 & 5 & 5 & 4 & 5 & 90 & $\begin{array}{l}\text { Sangat } \\
\text { Baik }\end{array}$ \\
\hline $\begin{array}{c}\text { Muhammad } \\
\text { Rizky }\end{array}$ & 2 & 3 & 2 & 4 & 2 & 2 & 50 & Cukup \\
\hline $\begin{array}{l}\text { Musfira } \\
\text { Achmad }\end{array}$ & 4 & 3 & 3 & 3 & 2 & 4 & 63 & Baik \\
\hline
\end{tabular}




\begin{tabular}{|c|c|c|c|c|c|c|c|l|}
\hline $\begin{array}{c}\text { Nur. Azizah } \\
\text { Al } \\
\text { Munawarah }\end{array}$ & 4 & 3 & 2 & 3 & 3 & 3 & 60 & Cukup \\
\hline $\begin{array}{c}\text { Nur Wafia } \\
\text { Utami }\end{array}$ & 2 & 4 & 2 & 3 & 4 & 3 & 60 & Cukup \\
\hline $\begin{array}{c}\text { Nurul Afika } \\
\text { Sari }\end{array}$ & 3 & 4 & 4 & 2 & 5 & 3 & 70 & Cukup \\
\hline $\begin{array}{c}\text { Putri } \\
\text { Meilani }\end{array}$ & 4 & 4 & 5 & 4 & 5 & 5 & 90 & $\begin{array}{l}\text { Sangat } \\
\text { Baik }\end{array}$ \\
\hline $\begin{array}{c}\text { Rahmat } \\
\text { Fauzan Jamal }\end{array}$ & 5 & 4 & 4 & 5 & 5 & 5 & 93 & $\begin{array}{l}\text { Sangat } \\
\text { Baik }\end{array}$ \\
\hline $\begin{array}{c}\text { Ruslan } \\
\text { Sitti Fatimah } \\
\text { Assahra }\end{array}$ & 4 & 4 & 5 & 5 & 4 & 5 & 90 & $\begin{array}{l}\text { Sangat } \\
\text { Baik }\end{array}$ \\
\hline Umar & 3 & 4 & 4 & 3 & 3 & 4 & 70 & Baik \\
\hline
\end{tabular}




\section{LAMPIRAN IV}

\section{ANGKET DAN MINAT}


Tabel Angket Siklus I

\begin{tabular}{|c|c|c|c|c|c|c|c|c|c|c|c|c|c|}
\hline \multirow{2}{*}{$\begin{array}{c}\text { NO } \\
\text { ABSEN }\end{array}$} & \multirow[b]{2}{*}{ NAMA } & \multicolumn{10}{|c|}{ INDIKATOR } & \multirow{2}{*}{$\begin{array}{c}\text { NIL } \\
\mathrm{Al}\end{array}$} & \multirow[b]{2}{*}{ KATEGORI } \\
\hline & & 1 & 2 & 3 & 4 & 5 & 6 & 7 & 8 & 9 & $\begin{array}{l}1 \\
0\end{array}$ & & \\
\hline 1 & Ahmad Fakhry & 3 & 4 & 3 & 3 & 3 & 3 & 3 & 2 & 2 & 5 & 62 & Berminat \\
\hline 2 & Arman Maulana & 4 & 3 & 5 & 2 & 4 & 3 & 4 & 4 & 3 & 4 & 72 & Berminat \\
\hline 3 & Ayuni Salsabila & 5 & 4 & 5 & 4 & 5 & 2 & 4 & 2 & 2 & 5 & 76 & $\begin{array}{l}\text { Sangat } \\
\text { Berminat }\end{array}$ \\
\hline 4 & Bashlar Soleh & 2 & 1 & 3 & 3 & 1 & 2 & 3 & 3 & 2 & 2 & 44 & Cukup \\
\hline 5 & $\begin{array}{c}\text { Fitria Fadilah Al- } \\
\text { Madinah }\end{array}$ & 2 & 4 & 4 & 3 & 4 & 3 & 4 & 3 & 3 & 4 & 68 & Berminat \\
\hline 6 & Futri Alya Dewi & 1 & 2 & 2 & 2 & 2 & 1 & 3 & 4 & 3 & 2 & 44 & Cukup \\
\hline 7 & Keysyafira & 3 & 5 & 4 & 4 & 3 & 5 & 4 & 5 & 4 & 3 & 80 & Berminat \\
\hline 8 & Lutfiah & 1 & 3 & 2 & 1 & 2 & 4 & 5 & 6 & 3 & 3 & 60 & Cukup \\
\hline 9 & M. Fadil & 4 & 3 & 3 & 2 & 4 & 3 & 4 & 4 & 4 & 1 & 64 & Berminat \\
\hline 10 & M. Zidni Khatami & 1 & 1 & 2 & 1 & 1 & 2 & 1 & 2 & 3 & 1 & 30 & $\begin{array}{l}\text { Kurang } \\
\text { Berminat }\end{array}$ \\
\hline 11 & Muh. Al Fatir & 2 & 3 & 2 & 3 & 3 & 3 & 3 & 3 & 4 & 3 & 58 & Cukup \\
\hline 12 & $\begin{array}{c}\text { Muh. } \\
\text { Fahril Ramadhan }\end{array}$ & 1 & 1 & 1 & 1 & 1 & 4 & 4 & 4 & 4 & 1 & 44 & Cukup \\
\hline 13 & Muh. Fahrizal & 1 & 1 & 2 & 3 & 2 & 3 & 2 & 5 & 2 & 2 & 46 & Cukup \\
\hline 14 & Muh. Hatta Rahmat & 3 & 4 & 3 & 4 & 4 & 2 & 3 & 4 & 2 & 3 & 64 & Berminat \\
\hline 15 & Muh. Faiz Al-Qadri & 2 & 3 & 2 & 1 & 2 & 4 & 4 & 3 & 3 & 1 & 50 & Cukup \\
\hline 16 & $\begin{array}{l}\text { Muh. Fahdil Aksa } \\
\text { Ratu }\end{array}$ & 3 & 4 & 4 & 4 & 3 & 5 & 3 & 4 & 3 & 3 & 72 & Berminat \\
\hline 17 & $\begin{array}{l}\text { Muh. Farhan } \\
\text { Saputra }\end{array}$ & 4 & 4 & 5 & 5 & 4 & 3 & 4 & 3 & 4 & 5 & 82 & $\begin{array}{l}\text { Sangar } \\
\text { berminat }\end{array}$ \\
\hline 18 & Muh. Rizky & 2 & 3 & 2 & 1 & 2 & 2 & 3 & 2 & 5 & 2 & 48 & Cukup \\
\hline 19 & Musfira Achmad & 2 & 3 & 1 & 3 & 2 & 1 & 2 & 2 & 3 & 1 & 40 & $\begin{array}{l}\text { Kurang } \\
\text { Berminat }\end{array}$ \\
\hline 20 & $\begin{array}{l}\text { Nur Azizah Al } \\
\text { Munawarah }\end{array}$ & 4 & 3 & 2 & 3 & 3 & 4 & 5 & 3 & 3 & 3 & 66 & Berminat \\
\hline 21 & Nur Wafia Utami & 2 & 1 & 2 & 3 & 1 & 3 & 5 & 4 & 2 & 1 & 48 & Cukup \\
\hline 22 & Nurul Afika Sari & 3 & 4 & 4 & 2 & 5 & 2 & 5 & 3 & 4 & 3 & 70 & Berminat \\
\hline 23 & Putri Meilani & 4 & 4 & 5 & 4 & 5 & 3 & 4 & 1 & 3 & 5 & 76 & Berminat \\
\hline 24 & $\begin{array}{c}\text { Rahmat Fauzan } \\
\text { Jamal }\end{array}$ & 5 & 4 & 4 & 5 & 5 & 4 & 5 & 2 & 2 & 5 & 82 & $\begin{array}{l}\text { Sangat } \\
\text { Berminat }\end{array}$ \\
\hline 25 & Ruslan & 3 & 1 & 2 & 2 & 4 & 3 & 4 & 3 & 4 & 3 & 58 & Cukup \\
\hline 26 & Sitti Fatimah Assahra & 3 & 2 & 3 & 2 & 3 & 4 & 2 & 3 & 3 & 2 & 54 & Cukup \\
\hline 27 & Umar & 1 & 1 & 2 & 3 & 2 & 3 & 3 & 4 & 2 & 2 & 46 & Cukup \\
\hline
\end{tabular}


Tabel Angket Siklus II

\begin{tabular}{|c|c|c|c|c|c|c|c|c|c|c|c|c|c|}
\hline \multirow{2}{*}{ NO ABSEN } & \multirow{2}{*}{ NAMA } & \multicolumn{10}{|c|}{ INDIKATOR } & \multirow{2}{*}{ NILAI } & \multirow{2}{*}{ KATEGORI } \\
\hline & & 1 & 2 & 3 & 4 & 5 & 6 & 7 & 8 & 9 & 10 & & \\
\hline 1 & Ahmad Fakhry & 3 & 4 & 3 & 3 & 3 & 3 & 3 & 2 & 2 & 5 & 62 & Berminat \\
\hline 2 & Arman Maulana & 4 & 3 & 5 & 2 & 4 & 3 & 4 & 4 & 3 & 4 & 72 & Berminat \\
\hline 3 & Ayuni Salsabila & 5 & 4 & 5 & 4 & 5 & 4 & 4 & 2 & 4 & 5 & 84 & $\begin{array}{l}\text { Sangat } \\
\text { Berminat }\end{array}$ \\
\hline 4 & Bashlar Soleh & 2 & 1 & 3 & 3 & 1 & 2 & 3 & 3 & 2 & 2 & 44 & Cukup \\
\hline 5 & Fitria Fadilah Al- Madinah & 2 & 4 & 4 & 3 & 4 & 3 & 4 & 3 & 3 & 4 & 68 & Berminat \\
\hline 6 & Futri Alya Dewi & 1 & 2 & 2 & 2 & 2 & 1 & 3 & 4 & 3 & 2 & 44 & Berminat \\
\hline 7 & Keysyafira & 3 & 5 & 4 & 4 & 3 & 5 & 4 & 5 & 4 & 3 & 80 & Berminat \\
\hline 8 & Lutfiah & 4 & 4 & 2 & 4 & 4 & 4 & 5 & 6 & 4 & 5 & 84 & $\begin{array}{l}\text { Sangat } \\
\text { Berminat }\end{array}$ \\
\hline 9 & M. Fadil & 4 & 3 & 3 & 2 & 4 & 3 & 4 & 4 & 4 & 1 & 64 & Berminat \\
\hline 10 & M. Zidni Khatami & 4 & 5 & 4 & 3 & 4 & 4 & 4 & 4 & 5 & 4 & 82 & $\begin{array}{l}\text { Sangat } \\
\text { Berminat }\end{array}$ \\
\hline 11 & Muh. Al Fatir & 2 & 3 & 2 & 3 & 3 & 3 & 3 & 3 & 4 & 3 & 58 & Cukup \\
\hline 12 & Muh. Fahril Ramadhan & 4 & 4 & 4 & 5 & 5 & 5 & 4 & 3 & 4 & 4 & 84 & $\begin{array}{l}\text { Sangat } \\
\text { Berminat }\end{array}$ \\
\hline 13 & Muh. Fahrizal & 1 & 1 & 2 & 3 & 2 & 3 & 2 & 5 & 2 & 2 & 46 & Cukup \\
\hline 14 & Muh. Hatta Rahmat & 3 & 4 & 3 & 4 & 4 & 2 & 3 & 4 & 2 & 3 & 64 & Berminat \\
\hline 15 & Muh. Faiz Al-Qadri & 4 & 4 & 4 & 5 & 5 & 5 & 5 & 4 & 3 & 4 & 86 & $\begin{array}{l}\text { Sangat } \\
\text { Berminat }\end{array}$ \\
\hline 16 & Muh. Fahdil Aksa Ratu & 3 & 4 & 4 & 4 & 3 & 5 & 3 & 4 & 3 & 3 & 72 & Berminat \\
\hline 17 & Muh. Farhan Saputra & 4 & 4 & 5 & 5 & 4 & 3 & 4 & 3 & 4 & 5 & 82 & $\begin{array}{l}\text { Sangat } \\
\text { Berminat }\end{array}$ \\
\hline 18 & Muh. Rizky & 2 & 3 & 2 & 1 & 2 & 2 & 3 & 2 & 5 & 2 & 48 & Cukup \\
\hline 19 & Musfira Achmad & 4 & 4 & 4 & 5 & 5 & 4 & 4 & 5 & 4 & 5 & 88 & $\begin{array}{l}\text { Sangat } \\
\text { Berminat }\end{array}$ \\
\hline 20 & Nur Azizah Al Munawarah & 4 & 3 & 2 & 3 & 3 & 4 & 5 & 3 & 3 & 3 & 66 & Berminat \\
\hline 21 & Nur Wafia Utami & 2 & 1 & 2 & 3 & 1 & 3 & 5 & 4 & 2 & 1 & 48 & Cukup \\
\hline 22 & Nurul Afika Sari & 3 & 4 & 4 & 2 & 5 & 2 & 5 & 3 & 4 & 3 & 70 & Berminat \\
\hline 23 & Putri Meilani & 4 & 4 & 5 & 4 & 5 & 3 & 4 & 1 & 3 & 5 & 76 & Berminat \\
\hline 24 & Rahmat Fauzan Jamal & 5 & 4 & 4 & 5 & 5 & 4 & 5 & 2 & 2 & 5 & 82 & $\begin{array}{l}\text { Sangat } \\
\text { Berminat }\end{array}$ \\
\hline 25 & Ruslan & 3 & 4 & 4 & 4 & 5 & 5 & 5 & 5 & 3 & 4 & 84 & $\begin{array}{l}\text { Sangat } \\
\text { Berminat }\end{array}$ \\
\hline 26 & Sitti Fatimah Assahra & 3 & 2 & 3 & 2 & 3 & 4 & 2 & 3 & 3 & 2 & 54 & Cukup \\
\hline 27 & Umar & 4 & 4 & 4 & 5 & 4 & 4 & 5 & 4 & 3 & 4 & 82 & $\begin{array}{l}\text { Sangat } \\
\text { Berminat }\end{array}$ \\
\hline
\end{tabular}


Lampiran 2. Lembar Angket Minat Siswa

\begin{tabular}{|c|c|c|c|c|c|c|}
\hline No & Pernyataan & $\begin{array}{l}\text { Sangat } \\
\text { Kurang }\end{array}$ & Kurang & Cukup & Berminat & $\begin{array}{l}\text { Sangat } \\
\text { Berminat }\end{array}$ \\
\hline 1 & $\begin{array}{l}\text { Saya senang mengikuti } \\
\text { pelajaran Bahasa } \\
\text { Indonesia }\end{array}$ & & & & & \\
\hline 2 & $\begin{array}{l}\text { Saya rugi bila tidak } \\
\text { mengikuti pelajaran } \\
\text { Bahasa Indonesia }\end{array}$ & & & & & \\
\hline 3 & $\begin{array}{l}\text { Saya merasa pelajaran } \\
\text { Bahasa Indonesia } \\
\text { bermanfaat }\end{array}$ & & & & & \\
\hline 4 & $\begin{array}{l}\text { Saya menyerahkan tugas } \\
\text { Bahasa Indonesia tepat } \\
\text { waktu }\end{array}$ & & & & & \\
\hline 5 & $\begin{array}{l}\text { Saya berusaha } \\
\text { memahami pelajaran } \\
\text { Bahasa Indonesia }\end{array}$ & & & & & \\
\hline 6 & $\begin{array}{l}\text { Saya bertanya jika } \\
\text { kurang jelas }\end{array}$ & & & & & \\
\hline 7 & $\begin{array}{l}\text { Saya mengerjakan soal- } \\
\text { soal latihan di rumah }\end{array}$ & & & & & \\
\hline 8 & $\begin{array}{l}\text { Saya mendiskusikan } \\
\text { materi pelajaran }\end{array}$ & & & & & \\
\hline 9 & $\begin{array}{l}\text { Saya berusaha memiliki } \\
\text { buku Bahasa Indonesia }\end{array}$ & & & & & \\
\hline 10 & $\begin{array}{l}\text { Saya berusaha mencari } \\
\text { bahan di perpustakaan }\end{array}$ & & & & & \\
\hline & Jumlah & & & & & \\
\hline
\end{tabular}


Nama : Ayuni Salsabila

Kelas : III

Tabel Observasi minat:

\begin{tabular}{|c|c|c|c|c|c|c|}
\hline No & Pernyataan & $\begin{array}{l}\text { Sangat } \\
\text { Kurang } \\
\text { (1) }\end{array}$ & Kurang(2) & $\begin{array}{l}\text { Cukup } \\
\text { (3) }\end{array}$ & $\begin{array}{l}\text { Berminat } \\
\text { (4) }\end{array}$ & $\begin{array}{l}\text { Sangat } \\
\text { Berminat } \\
\text { (5) }\end{array}$ \\
\hline 1 & $\begin{array}{l}\text { Saya senang } \\
\text { mengikuti pelajaran } \\
\text { Bahasa Indonesia }\end{array}$ & & & & $\checkmark$ & \\
\hline 2 & $\begin{array}{l}\text { Saya rugi bila tidak } \\
\text { mengikuti pelajaran } \\
\text { Bahasa Indonesia }\end{array}$ & & & & $\checkmark$ & \\
\hline 3 & $\begin{array}{l}\text { Saya merasa } \\
\text { pelajaran Bahasa } \\
\text { Indonesia bermanfaat }\end{array}$ & & & & $\checkmark$ & \\
\hline 4 & $\begin{array}{l}\text { Saya menyerahkan } \\
\text { tugas Bahasa } \\
\text { Indonesia tepat waktu }\end{array}$ & & & & $\checkmark$ & \\
\hline 5 & $\begin{array}{l}\text { Saya berusaha } \\
\text { memahami pelajaran } \\
\text { Bahasa Indonesia }\end{array}$ & & & & & $\checkmark$ \\
\hline 6 & $\begin{array}{l}\text { Saya bertanya jika } \\
\text { kurang jelas }\end{array}$ & & & & & $\checkmark$ \\
\hline 7 & $\begin{array}{l}\text { Saya mengerjakan } \\
\text { soal-soal latihan di } \\
\text { rumah }\end{array}$ & & & & & $\checkmark$ \\
\hline 8 & $\begin{array}{l}\text { Saya mendiskusikan } \\
\text { materi pelajaran }\end{array}$ & & & & $\checkmark$ & \\
\hline 9 & $\begin{array}{l}\text { Saya berusaha } \\
\text { memiliki buku } \\
\text { Bahasa Indonesia }\end{array}$ & & & & $\checkmark$ & \\
\hline 10 & $\begin{array}{l}\text { Saya berusaha } \\
\text { mencari bahan di } \\
\text { perpustakaan }\end{array}$ & & & & $\checkmark$ & \\
\hline & Jumlah & & & & 28 & 15 \\
\hline
\end{tabular}

Pengolahan skor :

Skor maksimum $(\mathrm{SM})=50$

$$
\begin{aligned}
\text { Nilai } & =\frac{\text { Skor yang diperoleh }}{\text { Skor Total }} \times 100 \\
& =\frac{43}{50} \times 100 \\
& =86 \text { (Sangat Berminat })
\end{aligned}
$$




\section{LAMPIRAN V \\ VALIDASI INSTRUMEN ANGKET DAN \\ TES}


Lampiran 1. Uji Validitas angket

\begin{tabular}{|c|c|c|c|c|c|c|c|c|c|c|c|c|c|}
\hline \multirow{2}{*}{$\begin{array}{l}\text { No } \\
\text { Absen }\end{array}$} & \multicolumn{13}{|c|}{ Nomor Angket } \\
\hline & 1 & 2 & 3 & 4 & 5 & 6 & 7 & 8 & 9 & 10 & 11 & 12 & 13 \\
\hline 1 & 1 & 1 & 1 & 1 & 1 & 1 & 1 & 1 & 1 & 1 & 1 & 1 & 1 \\
\hline 2 & 1 & 1 & 1 & 1 & 1 & 1 & 1 & 0 & 0 & 1 & 0 & 1 & 1 \\
\hline 3 & 1 & 0 & 0 & 1 & 1 & 1 & 1 & 1 & 1 & 1 & 0 & 1 & 1 \\
\hline 4 & 1 & 1 & 1 & 1 & 1 & 0 & 1 & 1 & 1 & 1 & 1 & 1 & 1 \\
\hline 5 & 1 & 1 & 1 & 1 & 0 & 1 & 0 & 0 & 0 & 0 & 0 & 0 & 1 \\
\hline 6 & 1 & 0 & 1 & 0 & 0 & 0 & 0 & 0 & 0 & 0 & 0 & 0 & 0 \\
\hline 7 & 1 & 0 & 0 & 1 & 1 & 1 & 1 & 0 & 0 & 1 & 1 & 1 & 1 \\
\hline 8 & 0 & 0 & 1 & 0 & 1 & 0 & 1 & 0 & 0 & 1 & 0 & 0 & 1 \\
\hline 9 & 0 & 0 & 0 & 1 & 0 & 1 & 0 & 0 & 1 & 0 & 1 & 0 & 1 \\
\hline 10 & 1 & 0 & 1 & 1 & 1 & 1 & 1 & 1 & 1 & 0 & 1 & 1 & 1 \\
\hline 11 & 1 & 0 & 1 & 1 & 1 & 1 & 0 & 0 & 0 & 0 & 0 & 0 & 1 \\
\hline 12 & 1 & 1 & 1 & 1 & 1 & 1 & 1 & 1 & 1 & 1 & 1 & 1 & 0 \\
\hline 13 & 1 & 1 & 1 & 1 & 1 & 1 & 1 & 1 & 1 & 1 & 1 & 1 & 1 \\
\hline 14 & 1 & 1 & 0 & 1 & 1 & 1 & 1 & 1 & 0 & 1 & 1 & 1 & 0 \\
\hline 15 & 1 & 0 & 1 & 1 & 0 & 1 & 0 & 1 & 1 & 0 & 1 & 0 & 1 \\
\hline 16 & 1 & 1 & 1 & 1 & 0 & 1 & 0 & 1 & 0 & 0 & 1 & 1 & 1 \\
\hline 17 & 1 & 1 & 0 & 1 & 1 & 1 & 1 & 1 & 1 & 1 & 1 & 1 & 0 \\
\hline 18 & 1 & 1 & 1 & 1 & 1 & 1 & 1 & 1 & 1 & 1 & 1 & 1 & 1 \\
\hline 19 & 1 & 1 & 0 & 1 & 1 & 1 & 1 & 0 & 1 & 1 & 0 & 1 & 1 \\
\hline 20 & 1 & 0 & 0 & 0 & 1 & 1 & 0 & 0 & 0 & 0 & 0 & 0 & 1 \\
\hline 21 & 1 & 0 & 1 & 0 & 0 & 1 & 0 & 1 & 0 & 0 & 0 & 0 & 1 \\
\hline 22 & 1 & 1 & 0 & 0 & 1 & 0 & 1 & 0 & 0 & 0 & 1 & 1 & 1 \\
\hline 23 & 0 & 0 & 0 & 1 & 1 & 1 & 0 & 0 & 1 & 1 & 1 & 1 & 0 \\
\hline 24 & 0 & 0 & 1 & 1 & 0 & 1 & 0 & 0 & 0 & 1 & 1 & 1 & 1 \\
\hline 25 & 0 & 0 & 0 & 1 & 0 & 1 & 0 & 0 & 0 & 1 & 0 & 0 & 0 \\
\hline 26 & 1 & 1 & 1 & 1 & 1 & 1 & 1 & 1 & 1 & 1 & 1 & 1 & 1 \\
\hline 27 & 1 & 1 & 1 & 1 & 1 & 1 & 1 & 1 & 1 & 1 & 1 & 1 & 1 \\
\hline $\begin{array}{l}r \\
\text { hitung }\end{array}$ & .502 & .726 & .120 & .370 & .675 & .122 & .820 & .632 & .595 & .497 & .415 & .778 & .099 \\
\hline$r$ tabel & .361 & .361 & .361 & .361 & .361 & .361 & .361 & .361 & .361 & .361 & .361 & .361 & .361 \\
\hline Kriteria & Valid & Valid & $\begin{array}{l}\text { tidak } \\
\text { valid }\end{array}$ & Valid & Valid & $\begin{array}{l}\text { tidak } \\
\text { valid }\end{array}$ & Valid & Valid & Valid & Valid & Valid & Valid & $\begin{array}{l}\text { tidak } \\
\text { valid }\end{array}$ \\
\hline
\end{tabular}




\section{LAMPIRAN VI}

\section{FOTO DOKUMENTASI}




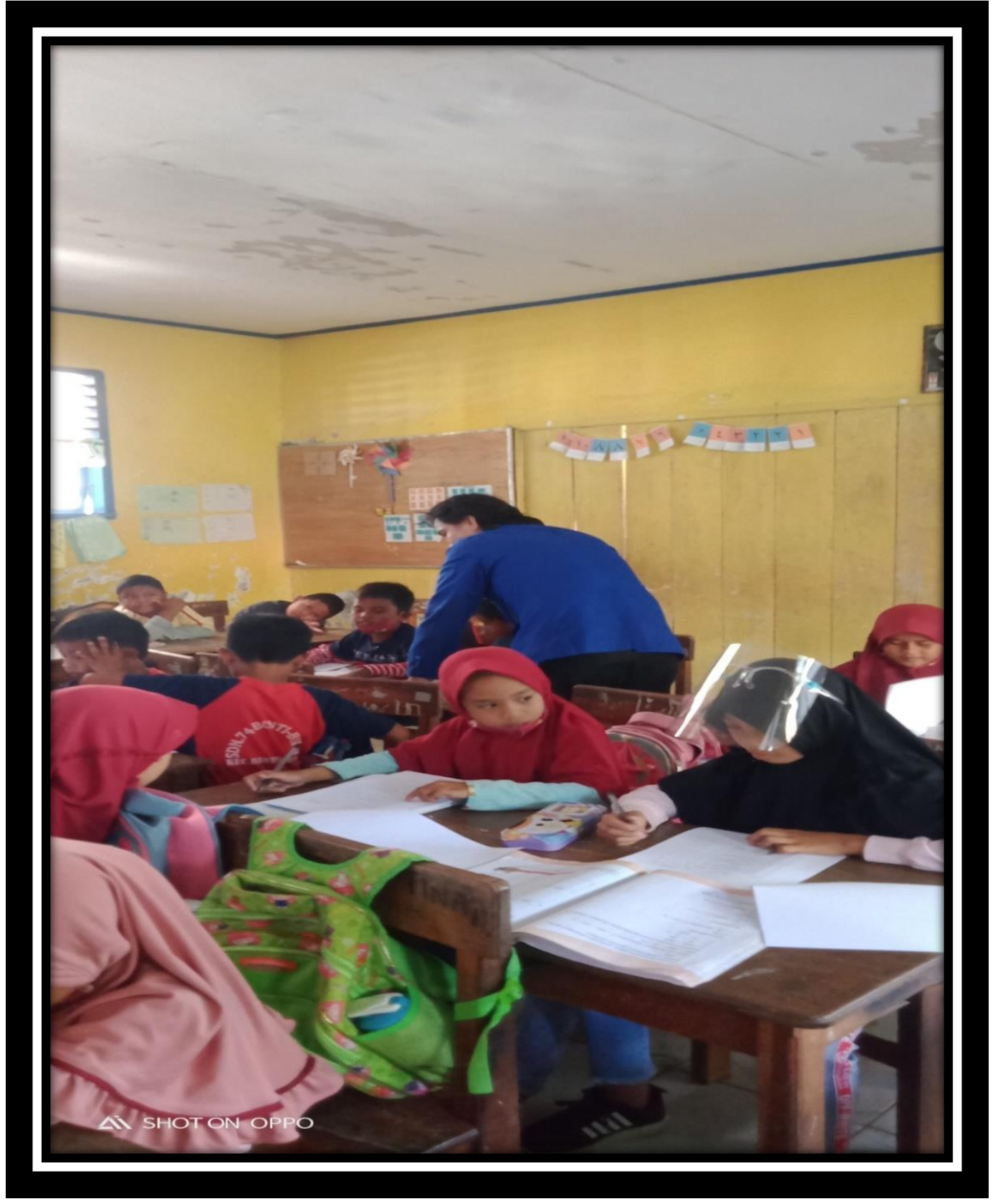

Proses pembelajaran Siklus I 


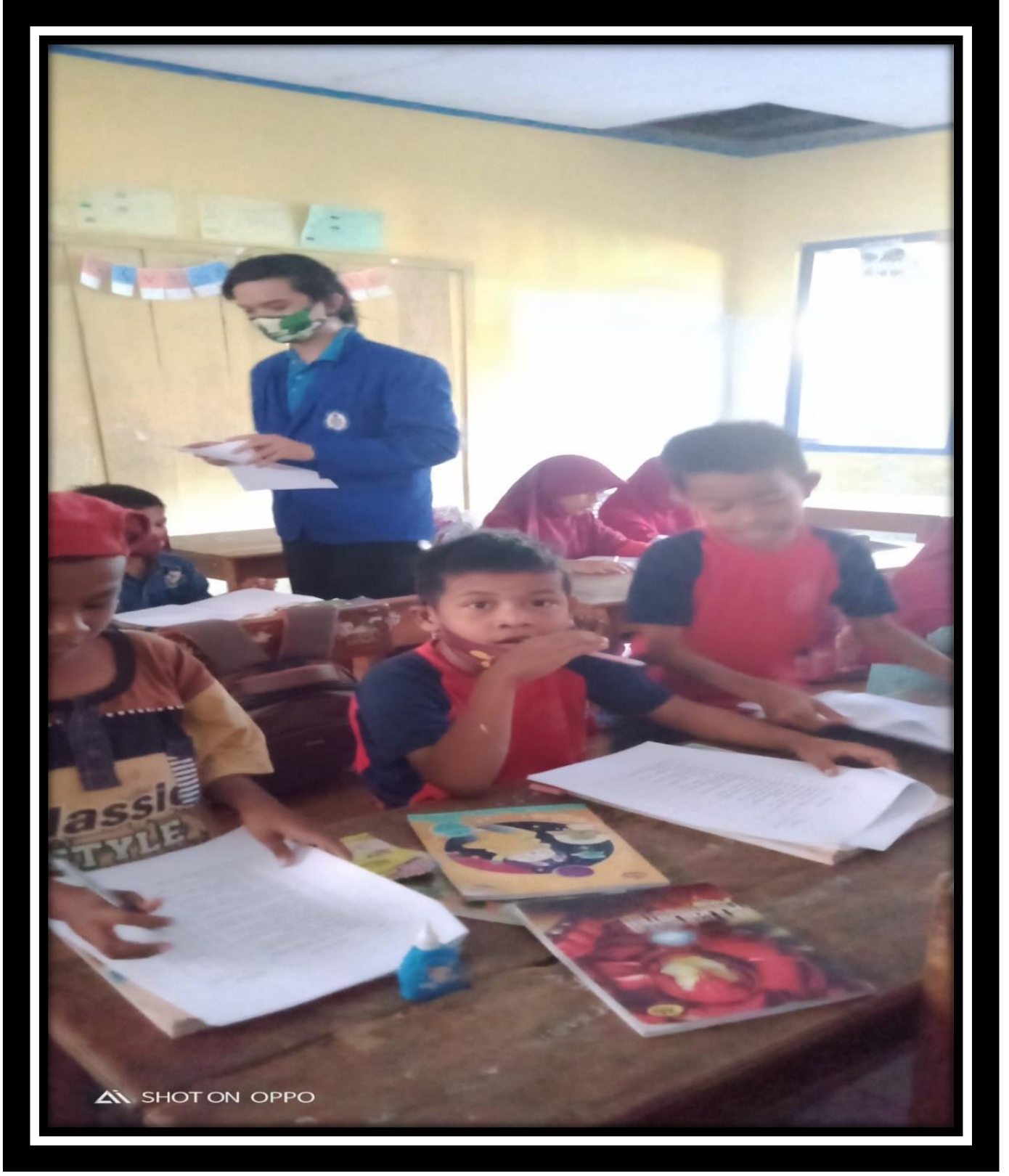

Proses Pembelajaran Siklus I 


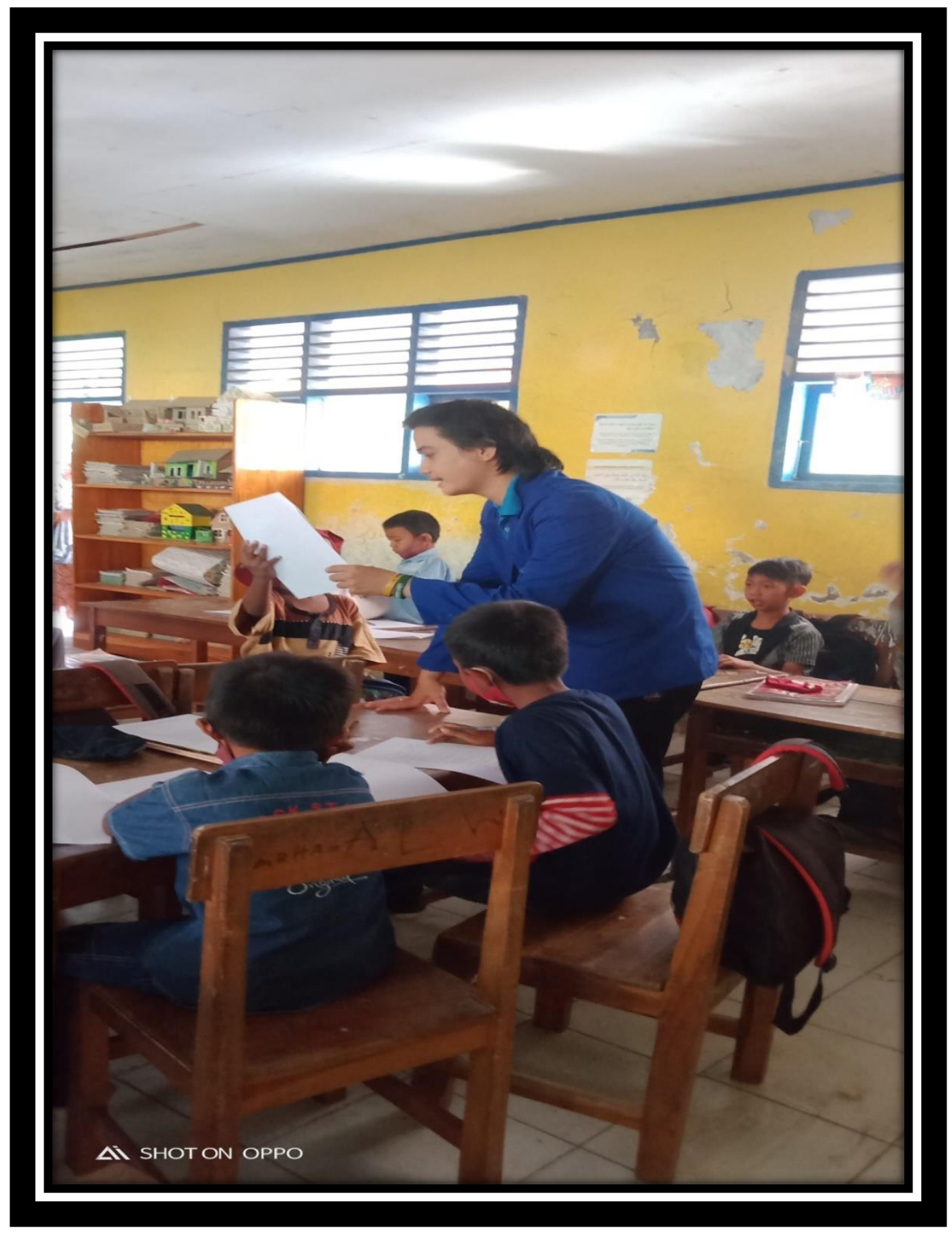

Proses Pembelajaran Siklus II 


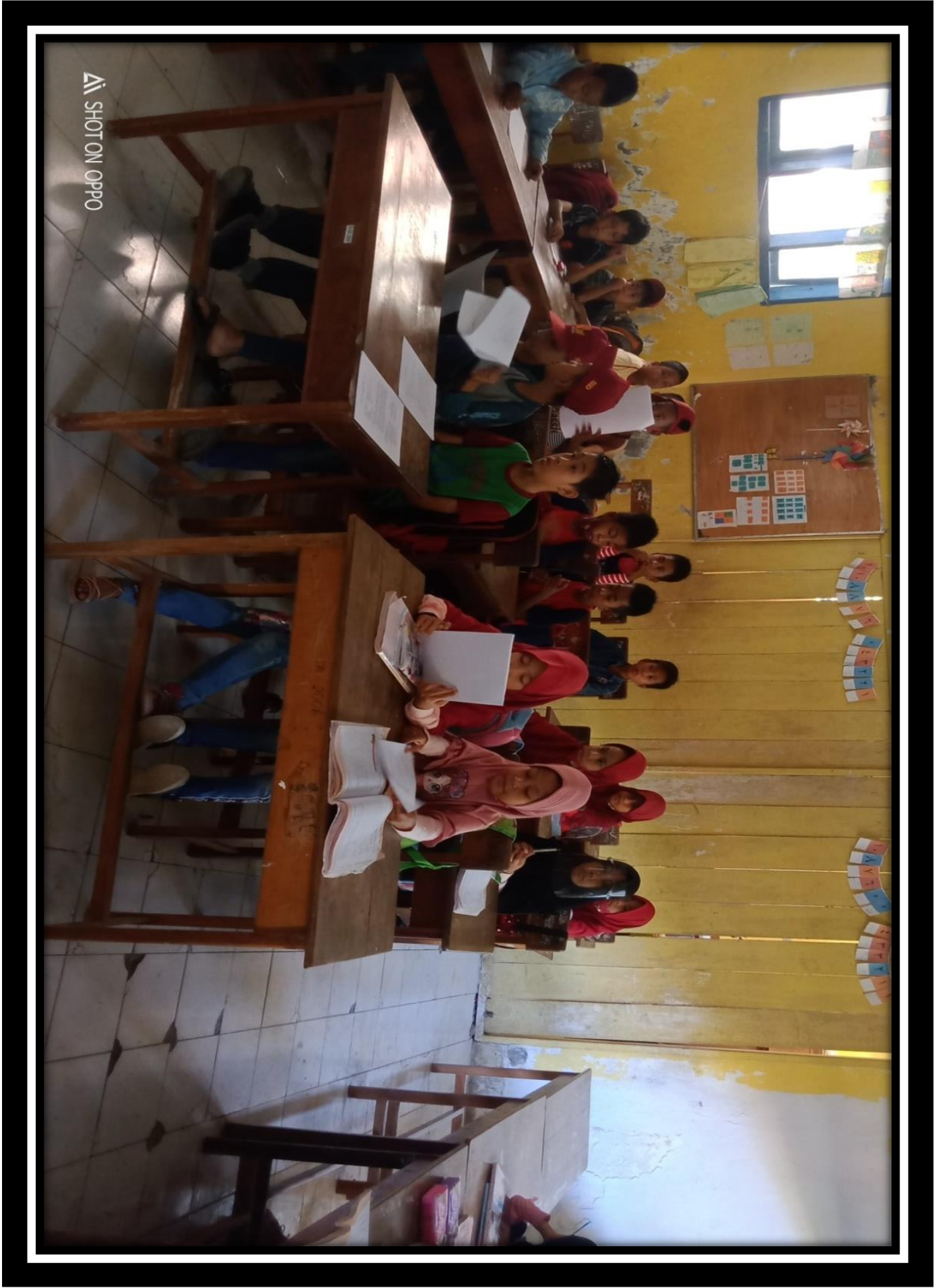

Proses Pembelajaran Siklus II 


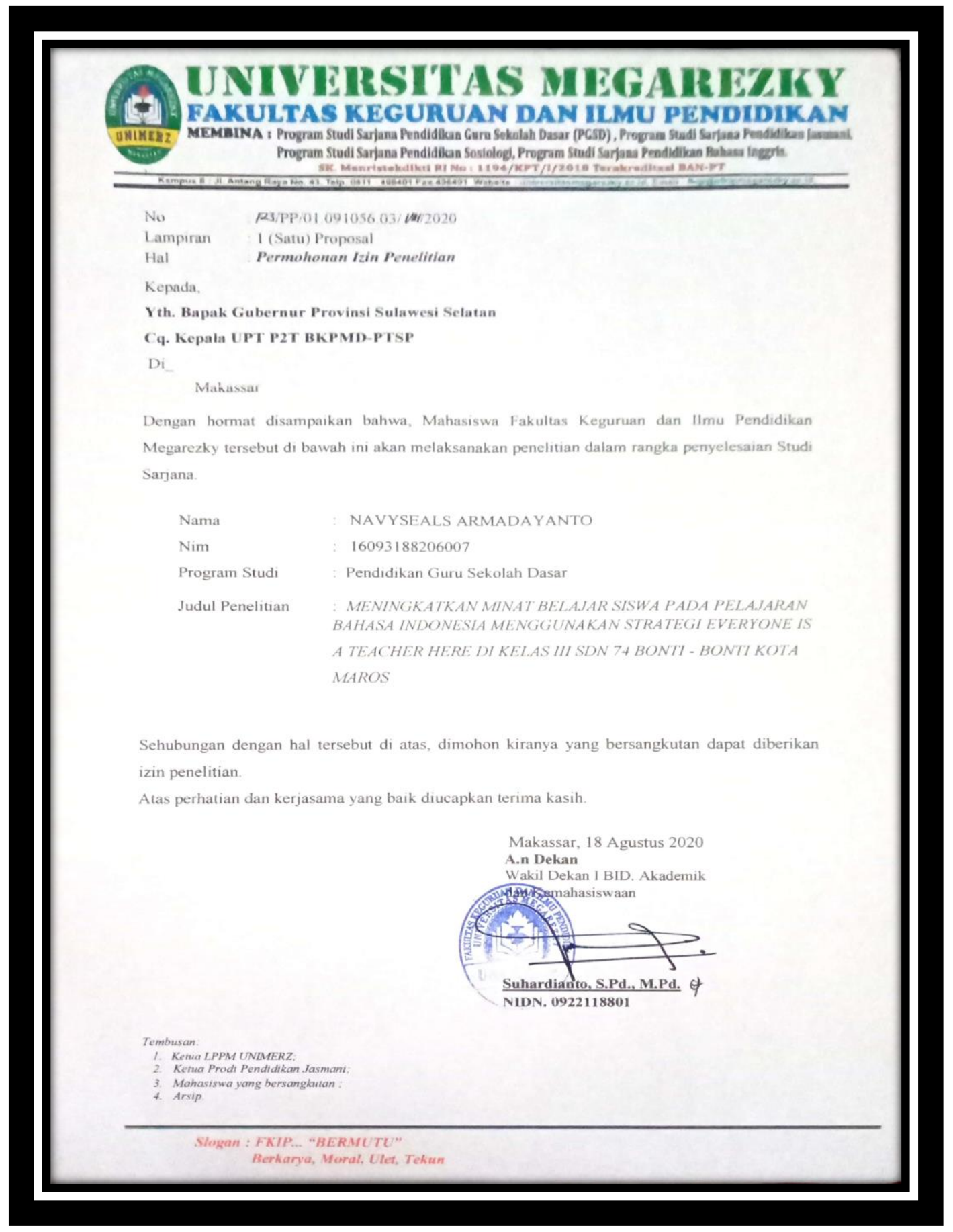




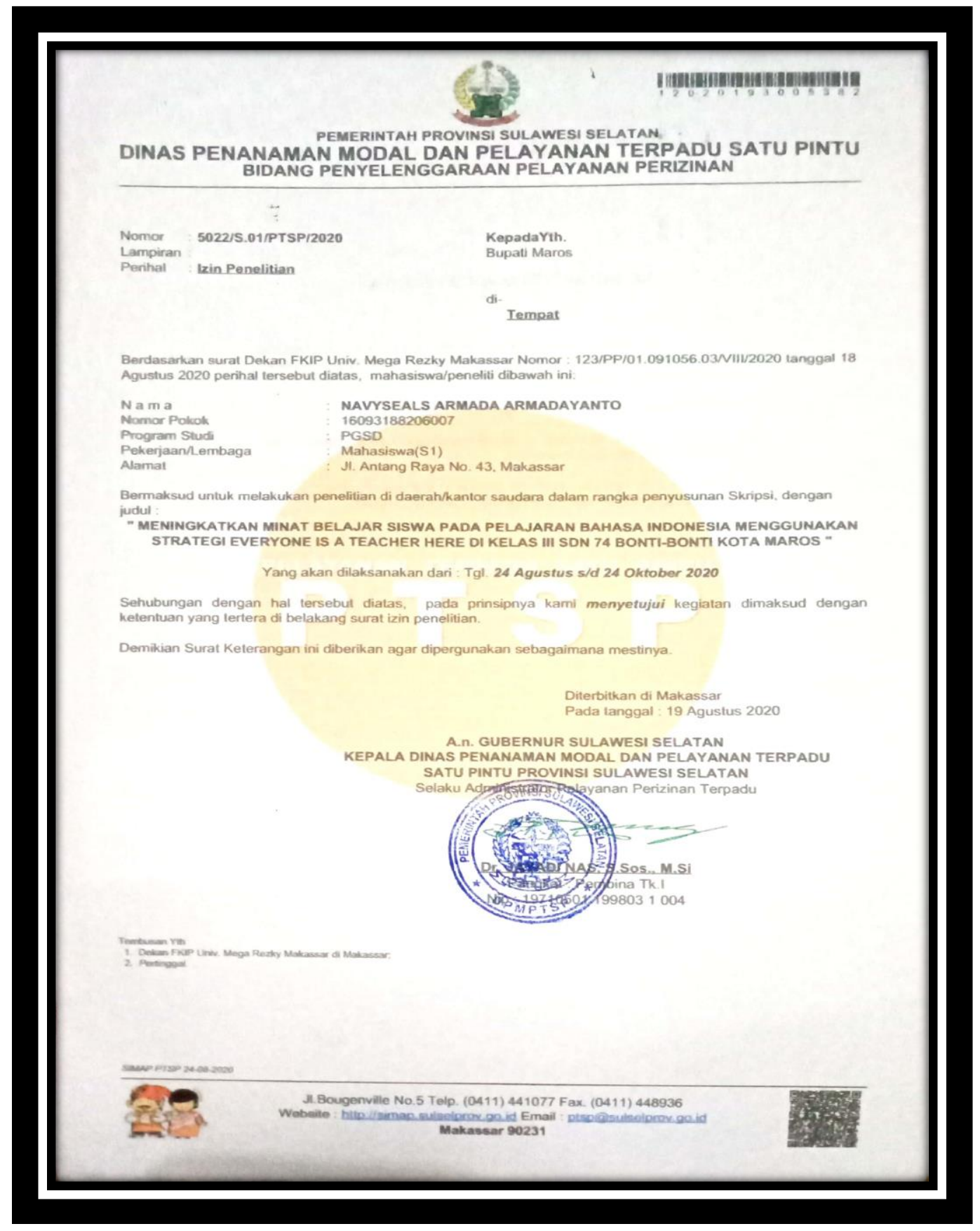




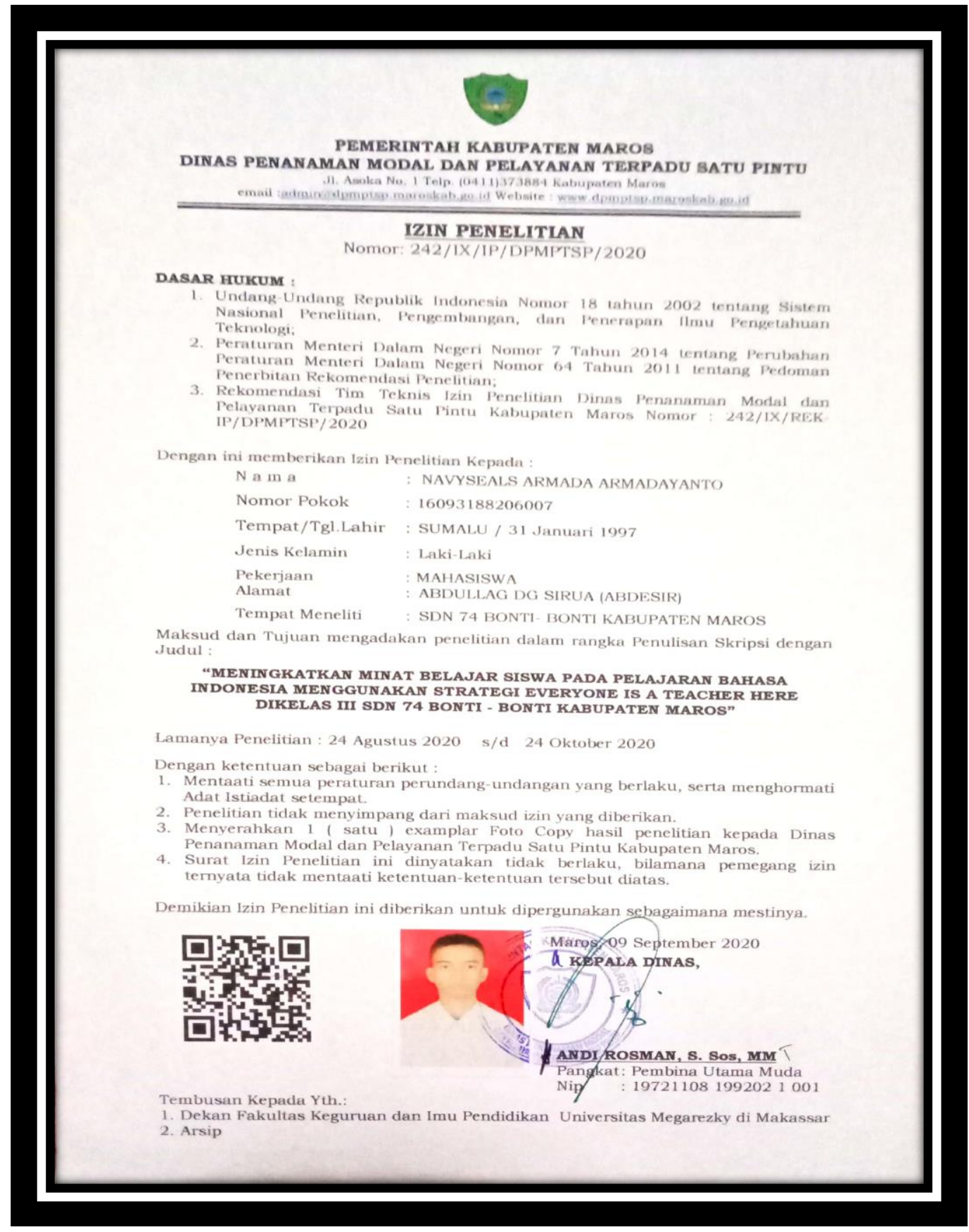




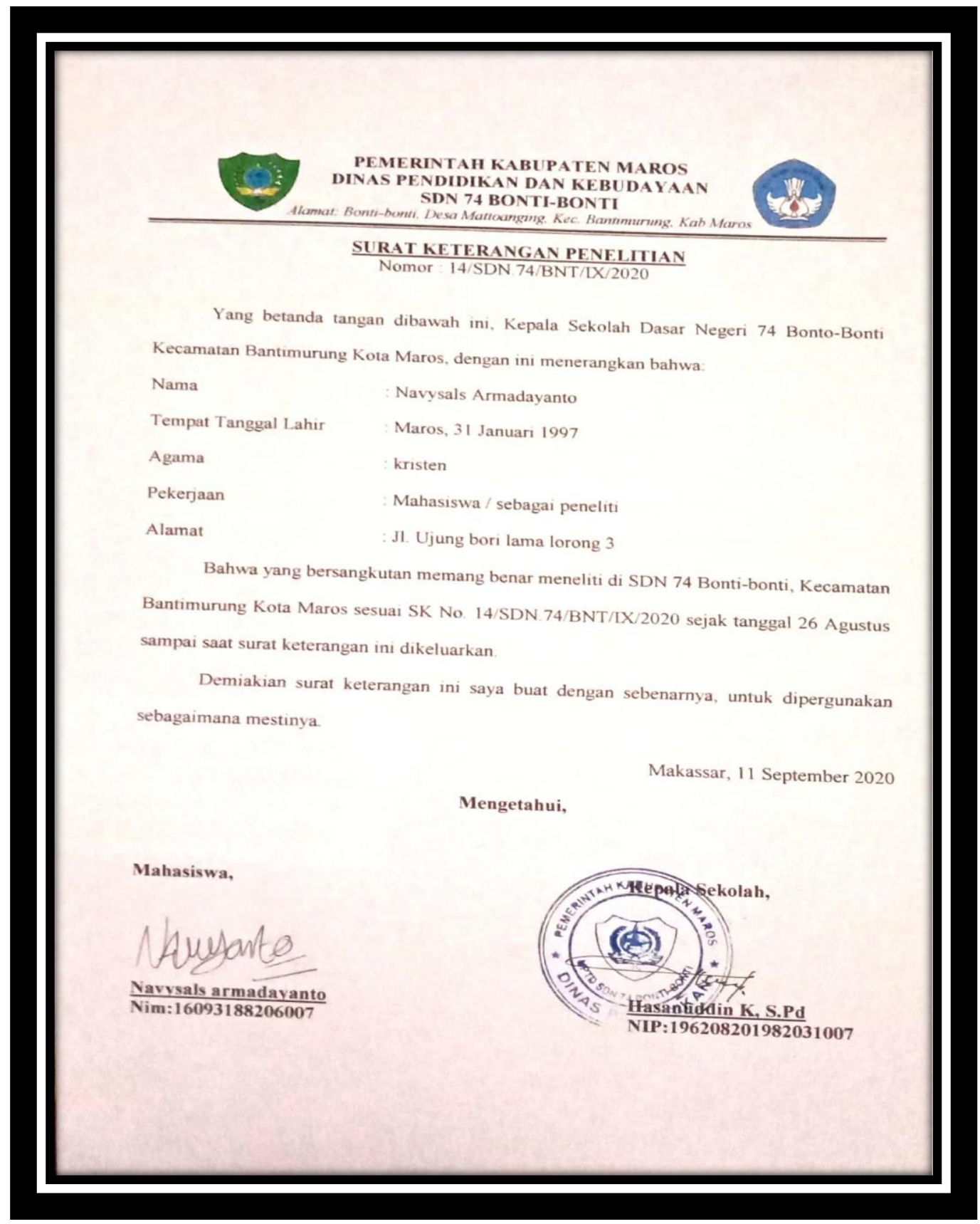




\section{DAFTAR RIWAYAT HIDUP}

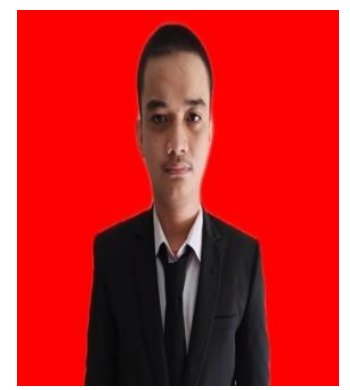

NAVYSEALS ARMADAYANTO. Lahir di Sumalu 31 Januari 1997, merupakan anak pertama dari tiga bersaudara. Dari pasangan Bapak Caya dan Ibu Marlin paturu penulis mengawali pendidikan di SD Negeri Melayu Makassar pada tahun 2003-2008, kemudian melanjutkan pendidikan di SMP Negeri 7 Makassar pada tahun 2008-2011, penulis melanjutkan sekolah ke jenjang yang lebih tinggi di SMA HANG TUAH Makassar dan lulus pada tahun 2014. Pada tahun 2016 penulis di terima sebagai mahasiswa program studi Pendidikan Guru Sekolah Dasar (PGSD) Fakultas Keguruan dan Ilmu Pendidikan di Universitas Megarezky. Selama menempuh bangku perkuliahan penulis aktif dibeberapa kegiatan Organisasi Pramuka. Pada tahun 2018 penulis menjadi anggota organisasi pramuka. Tahun 20182019 penulis menjabat sebagai Bendahara umum pramuka putra yang berpangkalan di Universitas Megarezky. 